\title{
The Potential of Indonesian Heterobranchs Found around Bunaken Island for the Production of Bioactive Compounds
}

\author{
Katja M. Fisch ${ }^{1,2}$, Cora Hertzer ${ }^{2}$, Nils Böhringer ${ }^{1,2}$, Zerlina G. Wuisan ${ }^{1,2}$, Dorothee Schillo ${ }^{3}$, \\ Robert Bara ${ }^{4}$, Fontje Kaligis ${ }^{4}$, Heike Wägele ${ }^{3}$, Gabriele M. König ${ }^{2,5, *}$ and Till F. Schäberle ${ }^{1,2,5, *}$ \\ 1 Institute for Insect Biotechnology, Justus-Liebig-University Giessen, 35392 Giessen, Germany; \\ Katja.M.Fisch@agrar.uni-giessen.de (K.M.F.); nils.boehringer@uni-bonn.de (N.B.); \\ Zerlina.G.Wuisan@bio.uni-giessen.de (Z.G.W.) \\ 2 Institute for Pharmaceutical Biology, Rheinische Friedrich-Wilhelms-University Bonn, 53115 Bonn, Germany; \\ s6coherz@uni-bonn.de \\ 3 Centre of Molecular Biodiversity, Zoological Research Museum Alexander Koenig, 53113 Bonn, Germany; \\ doro.schillo@gmail.com (D.S.); H.Waegele@leibniz-zfmk.de (H.W.) \\ 4 Faculty of Fisheries and Marine Science, Sam Ratulangi University, Manado 95115, Indonesia; \\ robert.bara@unsrat.ac.id (R.B.); fontjekaligis@yahoo.com (F.K.) \\ 5 German Center for Infection Research, Partner Site Bonn-Cologne, 53115 Bonn, Germany \\ * Correspondence: g.koenig@uni-bonn.de (G.M.K.); till.f.schaeberle@agrar.uni-giessen.de (T.F.S.); \\ Fax: +49-228-73-3250 (G.M.K.); +49-641-99-37149 (T.F.S.)
}

Received: 14 July 2017; Accepted: 28 November 2017; Published: 7 December 2017

\begin{abstract}
The species diversity of marine heterobranch sea slugs found on field trips around Bunaken Island (North Sulawesi, Indonesia) and adjacent islands of the Bunaken National Marine Park forms the basis of this review. In a survey performed in 2015, 80 species from 23 families were collected, including 17 new species. Only three of these have been investigated previously in studies from Indonesia. Combining species diversity with a former study from 2003 reveals in total 140 species from this locality. The diversity of bioactive compounds known and yet to be discovered from these organisms is summarized and related to the producer if known or suspected (might it be down the food chain, de novo synthesised from the slug or an associated bacterium). Additionally, the collection of microorganisms for the discovery of natural products of pharmacological interest from this hotspot of biodiversity that is presented here contains more than 50 species that have never been investigated before in regard to bioactive secondary metabolites. This highlights the great potential of the sea slugs and the associated microorganisms for the discovery of natural products of pharmacological interest from this hotspot of biodiversity.
\end{abstract}

Keywords: bioactivity; biodiversity; natural products; sea slug

\section{Introduction}

Eat or be eaten-many mechanisms have evolved during millions of years to prevent organisms falling into the second group. Most mollusks (soft-bodied marine organisms) use the mechanical properties of a shell to protect themselves from predators. However, loss of the shell in several mollusk groups indicates that a shell is an obstruction for some lifestyles. Hence, as a result new strategies have to be developed to protect these animals against predators. Octopuses and squids are responsive and fast, thereby able to escape potential predators by speed. Gastropoda (snails and slugs) instead must rely on other mechanisms to survive common predators like fish, crabs or echinoderms. Beside camouflage, they mostly use chemicals for protection, either by incorporation and use of cnidocysts and the toxins therein from their prey, or by sequestration of other chemical weapons. It has been 
shown that sea slugs, e.g., Phyllodesmium species, apply the chemical diversity of their specific food source as defensive mechanisms [1]. Compounds which have been isolated from the coral food were obtained in much higher amounts from the slugs, indicating the accumulation of these metabolites. Further, de novo synthesis of defensive metabolites by slugs is reported [2-4]. However, it has to be kept in mind that compounds may also be produced by bacteria associated with the sea slug or their food, e.g., algae, sponges and bryozoa. This was exemplified by dolastatin 10 (1), first described from the anaspidean Dolabella auricularia and subsequently from cyanobacteria [5-7] on the algal food.

The entity of natural products isolated from marine mollusks is intriguing and would justify comprehensive books and review articles and many natural products have been reviewed previously in such $[8,9]$. This review however focusses on sea slug-derived molecules for which biological activity is proven to show the potential for human use or for understanding ecological context. Furthermore, a regional focus is applied, i.e., the species diversity of sea slugs found at field trips in Bunaken National Park (BNP; North Sulawesi, Indonesia, Table 1 in Section 3.1) forms the base to show the status of investigation and the diversity of bioactive compounds to be expected from this biodiversity hotspot. However, the natural products described from the same species in previous literature might be isolated from specimens collected at other locations around the globe. For comparison, this origin is always given. If a producer of a bioactive metabolite, e.g., the respective food source or associated bacteria, is known or suspected, this is pointed out. A summary of the species with previously indentified bioactive compounds and their putative origin is provided at the end of the review (Table 2).

\section{Scope of the Review and Methodology Applied}

The review focusses on bioactive compounds from heterobranchs and additionally applies a regional focus. The expedition to BNP, which forms the basis for the species list used for this review (Table 1), took place in August 2015. Collecting areas comprised 16 sites with the focus on Bunaken Island (11 sites), three sites around Manado Tua, one site at Siladen Island and one site opposite to Bunaken Island along the mainland of North Sulawesi (Tiwoho), not belonging to the BNP. Although some sites were revisited (e.g., during the night), the collecting area rarely overlaped with previous visits. Overall, 18 dives ( 16 during daytime and two dives during night) with $3-5$ divers were performed, and several hours were spent snorkelling at the dive spots. One dive usually lasted $60 \mathrm{~min}$, with a few exceptions of up to $120 \mathrm{~min}$, rendering the total amount of underwater searching time to about 100 to $120 \mathrm{~h}$ manpower. Prior experience in searching and collecting sea slugs under water varies between the divers from extremely high (one diver with daily experience for several years), up to medium (two divers) and marginal experience (two divers).

Sea slugs were always collected directly from substrate in the field by scuba diving or by snorkelling. We documented the collected species by under-water photography as well as close up pictures and identification was checked by consulting most recently published identification books [10-12], by seaslugforum (www.seaslugforum.net), or primary literature (e.g., [13,14]). Validity of names was checked with the help of the World Register of Marine Species (www.marinespecies.org) and with Gosliner et al. (2015) [12]. Systematics in marine heterobranchs has changed considerably in the last decade and therefore old and new names are given for better understanding, especially when older literature is involved. It has to be mentioned that no substrate samples (algae, sediment or coral rubble) were collected. Thus, tiny and interstitial heterobranchs are certainly missing. However, these especially small species do not represent good starting material for chemical investigations, since the material would be extremely limiting. The metadata of the animals will be available in Diversity Collection (Diversity Workbench). Usually, a small piece of the animals was taken and stored in 96\% $\mathrm{EtOH}$ for future barcoding, which is currently work in progress. All material was collected with necessary permissions according to the Nagoya Protocol.

This review focusses on bioactive compounds, i.e., compounds for which a bioactivity has been previously tested and confirmed. As it might be the case that bioactivity was detected later than the initial decription of the natural product, after a search for each detected heterobranch genus name 
using Pubmed (https:/ / www.ncbi.nlm.nih.gov/pubmed), the names of the identified compounds were also used as a search term in the same database. Papers of interest were followed up in both directions, i.e., in literature they cite and in literature these papers were cited in using Web of Science, especially to make sure structural amendments and more specific literature has not been overlooked. Structurally related non-active compounds, reported from the same species were included in some cases to show structural diversity, e.g., sesquiterpenes from Phyllidia species. Of course, it might be the case that some compounds possess any bioactivity which is not identified until now. However, for the purpose of this review, we focus on the compounds with established bioactivity, including anticancer, antimicrobial, anthelminthic, antifouling, anti-inflammatory, ichthyotoxic and fish deterrent activity.

\section{Natural Products with Biological Activity from Heterobranchia Families Found near Bunaken}

\subsection{Biodiversity of Sea Slugs Found in the Bunaken National Park Survey}

Studies on marine heterobranchs from specific Indonesian areas are rare. Usually records are listed in general studies or identification books. Only a few studies assessing biodiversity of these slugs are focussing on one locality. The most extensive studied area of Indonesia is Ambon (part of the Maluku Islands) $[13,15,16]$. The second most studied is probably Bali; also included in a recent sea slug census in Lembeh (North Sulawesi) and Bali finding only 8 species at both locations and 51 unique to Lembeh vs. 27 to Bali [17]. However, the slug species in the census were identified only by field pictures and not documented in the scientific literature [17]. BNP, as the targeted area in the most Northern region of Indonesia, has only been surveyed once previously in order to assess molluscan diversity [18]. In this former study about 80 marine heterobranch species were recorded. During our collection in 2015, again around 80 heterobranch species were sampled (Table 1). However, only 21 species were recorded in both surveys (Kaligis et al. in revision). Thus, the combined species number recorded from BNP is nearly 140 species, including several undescribed species. The group known for their bioactive compounds, the Anthobranchia, are especially well represented now with more than 30 species (including probably three undescribed species) (Kaligis et al. in revision, Table 1). This indicates BNP as a study area of high species richness with a great potential to find species, not only in the pharmaceutically well studied group of Anthobranchia, but also in other less known groups, like the Cephalaspidea. According to the species composition that is certainly related to the coral habitats around BNP, some groups that are also known for their pharmaceutical importance are less represented. This mainly refers to the groups Sacoglossa and Anaspidea, which need habitats dominated by rich algal communities [19]. However, few representatives of these groups (even new species) were collected (Table 1). In the following review, all families that were represented by members in our collection are discussed in the light of bioactive compounds, be it already described compounds from that specific species in other localities), or by indicating their potential based on bioactive compounds in related species (see Tables 1 and 2). Only three studies report bioactive compounds from Indonesian heterobranchs, i.e., Pleurobranchus forskalii, Chromodoris lochi and Phyllidia varicosa. The unique peptide found in P. forskalii from Manado (Indonesia) (see Section 3.5.1 and Table 2) shows that even relatively well investigated species are of high interest, due to the intraspecific variances in compound composition in regard to geographic distribution and localities. Of special interest are also Heterobranchia families which have no reported bioactive compounds such as Diaphanidae, Goniodorididae, Gymnodoridae and Eubranchidae, which most likely have not been investigated so far. 
Table 1. Species diversity collected at Bunaken National Park (BNP) grouped by phylogenetic relatedness, localities of their collection, depth and abundance and indication of known chemistry.

\begin{tabular}{|c|c|c|c|c|c|}
\hline Clade & Family & Species & Locality & $\begin{array}{l}\text { Depth and } \\
\text { Abundance }\end{array}$ & $\begin{array}{l}\text { Bioactive } \\
\text { Compounds }\end{array}$ \\
\hline Anaspidae (sea hares) & Aplysiidae Lamarck, 1809 & $\begin{array}{c}\text { Stylocheilus striatus } \\
\text { (Quoy and Gaimard, 1832) }\end{array}$ & Bunaken & $10 \mathrm{~m}$; rare & see text and Table 2 \\
\hline \multirow[t]{10}{*}{ Sacoglossa } & Caliphyllidae Tiberi, 1881 & $\begin{array}{c}\text { Cyerce sp. } 4 \\
\text { (cf. Cyerce bourbonica Yonow, 2012) }\end{array}$ & Bunaken & 3-10 m; uncommon & nothing published \\
\hline & & Cyerce sp. 2 & Bunaken & 3-7 m; uncommon & nothing published \\
\hline & Oxynoidae Stoliczka, 1868 (1847) & Lobiger sp. 1 & Bunaken & $7 \mathrm{~m}$; rare & nothing published \\
\hline & & Lobiger viridis (Pease, 1863) & Bunaken & $8 \mathrm{~m}$; rare & nothing published \\
\hline & Plakobranchidae Gray, 1840 & $\begin{array}{l}\text { Elysia asbecki Wägele, Stemmer, } \\
\text { (Burghardt and Händeler, 2010) }\end{array}$ & $\begin{array}{l}\text { Bunaken, Manado Tua, } \\
\text { Siladen, Tiwoho }\end{array}$ & 4-15 m; uncommon & nothing published \\
\hline & & 3 undescribed Elysia species & Bunaken, Siladen & 5-9 m; rare & nothing published \\
\hline & & Thuridilla albopustulosa (Gosliner, 1995) & Bunaken & $6 \mathrm{~m}$; rare & nothing published \\
\hline & & Thuridilla flavomaculata (Gosliner, 1995) & Bunaken & $2-7 \mathrm{~m}$; rare & nothing published \\
\hline & & Thuridilla gracilis (Risbec, 1928) & Bunaken, Siladen & 3-8 m; uncommon & nothing published \\
\hline & & Thuridilla lineolata (Bergh, 1905) & $\begin{array}{l}\text { Bunaken, Siladen, } \\
\text { Tiwoho }\end{array}$ & 1-9 m; abundant & nothing published \\
\hline \multirow[t]{10}{*}{ Cephalaspidea } & Aglajidae Pilsbry, 1895 (1847) & unidentified specimen & Tiwoho & $5 \mathrm{~m}$; rare & nothing published \\
\hline & & Chelidonura amoena (Bergh, 1905) & Bunaken & $1 \mathrm{~m}$; rare & nothing published \\
\hline & & $\begin{array}{l}\text { Chelidonura hirundinina } \\
\text { (Quoy and Gaimard, 1833) }\end{array}$ & Bunaken, Manado Tua & $5 \mathrm{~m}$; rare & nothing published \\
\hline & & Odontoglaja guamensis (Rudman, 1978) & $\begin{array}{l}\text { Bunaken, Manado Tua, } \\
\text { Tiwoho }\end{array}$ & 3-19 m; uncommon & nothing published \\
\hline & Diaphanidae Odhner, 1914 (1857) & Colpodaspis thompsoni (G. H. Brown, 1979) & $\begin{array}{l}\text { Bunaken, Manado Tua, } \\
\text { Siladen, Tiwoho }\end{array}$ & 4-11 m; uncommon & nothing published \\
\hline & Gastropteridae Swainson, 1840 & $\begin{array}{l}\text { Sagaminopteron psychedelicum } \\
\text { (Carlson and Hoff, 1974) }\end{array}$ & Bunaken, Manado Tua & 4-15 m; uncommon & see text and Table 2 \\
\hline & & $\begin{array}{l}\text { Siphopteron brunneomarginatum } \\
\text { (Carlson and Hoff, 1974) }\end{array}$ & $\begin{array}{l}\text { Bunaken, Manado Tua, } \\
\text { Siladen }\end{array}$ & 4-10 m; uncommon & nothing published \\
\hline & & $\begin{array}{l}\text { Siphopteron cf. ladrones } \\
\text { (Carlson and Hoff, 1974) }\end{array}$ & Bunaken & $5 \mathrm{~m}$; rare & nothing published \\
\hline & & $\begin{array}{l}\text { Siphopteron nigromarginatum } \\
\text { (Gosliner, 1989) }\end{array}$ & Manado Tua & $5 \mathrm{~m}$; rare & nothing published \\
\hline & & Siphopteron spec. & Bunaken & $4-5 \mathrm{~m}$; rare & nothing published \\
\hline
\end{tabular}


Table 1. Cont.

\begin{tabular}{|c|c|c|c|c|c|c|}
\hline Clade & & Family & Species & Locality & $\begin{array}{c}\text { Depth and } \\
\text { Abundance }\end{array}$ & $\begin{array}{l}\text { Bioactive } \\
\text { Compounds }\end{array}$ \\
\hline & & & Siphopteron tigrinum (Gosliner, 1989) & Bunaken & 5-6 m; rare & nothing published \\
\hline & & Haminoeidae Pilsbry, 1895 & 2 undescribed Haminoea species & $\begin{array}{c}\text { Bunaken, } \\
\text { Manado Tua, Siladen }\end{array}$ & $3-13 \mathrm{~m}$; rare & nothing published \\
\hline Pleurobranchomorpha & & Pleurobranchidae Gray, 1827 & $\begin{array}{c}\text { Pleurobranchus forskalii } \\
\text { (Rüppell and Leuckart, 1828) }\end{array}$ & Bunaken, Siladen & $4-8 \mathrm{~m}$; common & $\begin{array}{l}\text { see text and text } \\
\text { and Table } 2\end{array}$ \\
\hline \multirow[t]{19}{*}{ Nudibranchia } & Anthobranchia & Aegiridae P. Fischer, 1883 & $\begin{array}{c}\text { Notodoris serenae } \\
\text { (Gosliner and Behrens, 1997) }\end{array}$ & Manado Tua & $13 \mathrm{~m}$; rare & nothing published \\
\hline & & Chromodorididae Bergh, 1891 & Ceratosoma sp. 2 & Bunaken & 5-8 m; rare & nothing published \\
\hline & & & Chromodoris annae (Bergh, 1877) & $\begin{array}{l}\text { Bunaken, Manado Tua, } \\
\text { Siladen, Tiwoho }\end{array}$ & 4-23 m; abundant & nothing published \\
\hline & & & Chromodoris cf. boucheti (Rudman, 1982) & Siladen & $8 \mathrm{~m}$; rare & nothing published \\
\hline & & & $\begin{array}{c}\text { Chromodoris dianae } \\
\text { (Gosliner and Behrens, 1998) }\end{array}$ & $\begin{array}{l}\text { Bunaken, Manado Tua, } \\
\text { Siladen, Tiwoho }\end{array}$ & 4-21 m; abundant & nothing published \\
\hline & & & Chromodoris lochi (Rudman, 1982) & $\begin{array}{c}\text { Bunaken, } \\
\text { Manado Tua, Siladen }\end{array}$ & 5-17 m; common & see text and Table \\
\hline & & & Chromodoris strigata (Rudman, 1982) & Siladen & $11 \mathrm{~m}$; rare & nothing published \\
\hline & & & Chromodoris willani (Rudman, 1982) & $\begin{array}{c}\text { Bunaken, } \\
\text { Manado Tua, Siladen }\end{array}$ & 7-21 m; common & nothing published \\
\hline & & & $\begin{array}{l}\text { Doriprismatica (=Glossodoris) stellata } \\
\text { (Rudman, 1986) }\end{array}$ & Bunaken & 4-21 m; uncommon & nothing published \\
\hline & & & Glossodoris (=Casella) cincta (Bergh, 1888) & Tiwoho & $6 \mathrm{~m}$; rare & nothing published \\
\hline & & & Goniobranchus geometricus (Risbec, 1928) & Bunaken, Tiwoho & $4-8 \mathrm{~m}$; rare & nothing published \\
\hline & & & $\begin{array}{l}\text { Goniobranchus reticulatus } \\
\text { (Quoy and Gaimard, 1832) }\end{array}$ & Manado Tua & $15 \mathrm{~m}$; rare & nothing published \\
\hline & & & Hypselodoris maculosa (Pease, 1871) & Bunaken, Tiwoho & $4-6 \mathrm{~m}$; rare & nothing published \\
\hline & & $\begin{array}{c}\text { Dendrodorididae O'Donoghue, } \\
1924 \text { (1864) }\end{array}$ & Dendrodoris albobrunnea (Allan, 1933) & Bunaken & $4 \mathrm{~m}$; rare & nothing published \\
\hline & & & Dendrodoris nigra (Stimpson, 1855) & Bunaken & $4 \mathrm{~m}$; rare & see text and Table \\
\hline & & Discodorididae Bergh, 1891 & $\begin{array}{c}\text { Taringa halgerda } \\
\text { (Gosliner and Behrens, 1998) }\end{array}$ & Bunaken, Tiwoho & $6 \mathrm{~m}$; rare & nothing published \\
\hline & & & Halgerda carlsoni (Rudman, 1978) & Manado Tua & $5 \mathrm{~m}$; rare & nothing published \\
\hline & & & Halgerda tessellata (Bergh, 1880) & Siladen & $5 \mathrm{~m}$; rare & nothing published \\
\hline & & & Rostanga sp. 4 & Manado Tua & $13 \mathrm{~m}$; rare & nothing published \\
\hline
\end{tabular}


Table 1. Cont.

\begin{tabular}{|c|c|c|c|c|c|c|}
\hline \multirow[t]{18}{*}{ Clade } & & Family & Species & Locality & $\begin{array}{c}\text { Depth and } \\
\text { Abundance }\end{array}$ & $\begin{array}{l}\text { Bioactive } \\
\text { Compounds }\end{array}$ \\
\hline & & Hexabranchidae Bergh, 1891 & $\begin{array}{l}\text { Hexabranchus sanguineus } \\
\text { (Rüppell and Leuckart, 1830) }\end{array}$ & Bunaken & $2 \mathrm{~m}$; rare & see text and Table 2 \\
\hline & & $\begin{array}{l}\text { Goniodorididae H. Adams and } \\
\text { A. Adams, } 1854\end{array}$ & $\begin{array}{c}\text { Trapania euryeia } \\
\text { (Gosliner and Fahay, 2008) }\end{array}$ & Bunaken & $6 \mathrm{~m}$; rare & nothing published \\
\hline & & Gymnodorididae Odhner, 1941 & Gymnodoris sp. & Bunaken, Manado Tua & 5-7 m; rare & nothing published \\
\hline & & Phyllidiidae Rafinesque, 1814 & Phyllidia coelestis (Bergh, 1905) & $\begin{array}{c}\text { Bunaken, } \\
\text { Manado Tua, Tiwoho }\end{array}$ & $2-15 \mathrm{~m}$ & see text and Table 2 \\
\hline & & & Phyllidia elegans (Bergh, 1869) & Bunaken, Siladen & 2-19 m; uncommon & nothing published \\
\hline & & & Phyllidia ocellata (Cuvier, 1804) & Tiwoho & $5 \mathrm{~m}$; rare & see text and Table 2 \\
\hline & & & Phyllidia varicosa (Lamarck, 1801) & Bunaken & 4-21 m; uncommon & see text and Table 2 \\
\hline & & & Phyllidiella annulata (Gray, 1853) & Bunaken, Manado Tua & $11-13 \mathrm{~m}$; rare & nothing published \\
\hline & & & Phyllidiella pustulosa (Cuvier, 1804) & $\begin{array}{l}\text { Bunaken, Manado Tua, } \\
\text { Siladen, Tiwoho }\end{array}$ & 5-19 & see text and Table 2 \\
\hline & & & Phyllidiella striata (Bergh, 1889) & Bunaken & $15 \mathrm{~m}$; rare & nothing published \\
\hline & & & Phyllidiopsis pipeki (Brunckhorst, 1993) & Bunaken & 14-15 m; rare & nothing published \\
\hline & & & Phyllidiopsis sphingis (Brunckhorst, 1993) & Manado Tua & $19 \mathrm{~m}$; rare & nothing published \\
\hline & & $\begin{array}{l}\text { Polyceridae Alder and } \\
\text { Hancock, } 1845\end{array}$ & Nembrotha cristata (Bergh, 1877) & Bunaken, Siladen & $4-15 \mathrm{~m}$; rare & see text and Table 2 \\
\hline & & & Nembrotha kubaryana (Bergh, 1877) & Tiwoho & $6 \mathrm{~m}$; rare & see text and Table 2 \\
\hline & & & $\begin{array}{c}\text { Kaloplocamus dokte } \\
\text { (Vallès and Gosliner, 2006) }\end{array}$ & Bunaken & $7 \mathrm{~m}$; rare & nothing published \\
\hline & & & Polycera japonica (Baba, 1949) & Bunaken & $7-8 \mathrm{~m}$; rare & nothing published \\
\hline & & & Polycera risbeci (Odhner, 1941) & Bunaken & 7-8 m; rare & nothing published \\
\hline \multirow[t]{6}{*}{ Nudibranchia } & $\begin{array}{c}\text { Subclade } \\
\text { Cladobranchia }\end{array}$ & $\begin{array}{l}\text { Arminidae Iredale and } \\
\text { O'Donoghue, } 1923 \text { (1841) }\end{array}$ & $\begin{array}{l}\text { Dermatobranchus fasciatus } \\
\text { (Gosliner and Fahey, 2011) }\end{array}$ & Bunaken & $7 \mathrm{~m}$; rare & nothing published \\
\hline & & & $\begin{array}{l}\text { Dermatobranchus striatus } \\
\quad \text { (van Hasselt, 1824) }\end{array}$ & Manado Tua & $7 \mathrm{~m}$; rare & nothing published \\
\hline & & Eubranchidae Odhner, 1934 & Eubranchus sp. 4 & Bunaken & $18 \mathrm{~m}$; rare & nothing published \\
\hline & & Facelinidae Bergh, 1889 & Caloria indica (Bergh, 1896) & $\begin{array}{l}\text { Bunaken, Manado Tua, } \\
\text { Siladen, Tiwoho }\end{array}$ & 3-6 m; uncommon & nothing published \\
\hline & & & Favorinus japonicus (Baba, 1949) & Bunaken, Siladen & 5-10 m; uncommon & nothing published \\
\hline & & & Favorinus mirabilis (Baba, 1955) & Bunaken & $23 \mathrm{~m}$; rare & nothing published \\
\hline
\end{tabular}


Table 1. Cont.

\begin{tabular}{|c|c|c|c|c|c|}
\hline Clade & Family & Species & Locality & $\begin{array}{c}\text { Depth and } \\
\text { Abundance }\end{array}$ & $\begin{array}{l}\text { Bioactive } \\
\text { Compounds }\end{array}$ \\
\hline & & Favorinus tsuruganus (Baba and Abe, 1964) & Bunaken & 6-23 m; uncommon & nothing published \\
\hline & & Noumeaella sp. No. $1-2$ & Bunaken & 4-12 m; uncommon & nothing published \\
\hline & & Phyllodesmium briareum (Bergh, 1896) & Bunaken, Tiwoho & 2-7 m; abundant & see text and Table \\
\hline & & Phyllodesmium poindimiei (Risbec, 1928) & Bunaken & $17 \mathrm{~m}$; rare & nothing published \\
\hline & & Facelina rhodopos (Yonow, 2000) & Manado Tua & $15 \mathrm{~m}$; rare & nothing published \\
\hline & & Pteraeolidia semperi (Bergh, 1870) & $\begin{array}{l}\text { Bunaken, Manado Tua, } \\
\text { Siladen, Tiwoho }\end{array}$ & 4-15 m; common & nothing published \\
\hline & Flabellinidae Bergh, 1889 & Flabellina bicolor (Kelaart, 1858) & Siladen, Tiwoho & 3-6 m; rare & nothing published \\
\hline & & $\begin{array}{c}\text { Flabellina exoptata } \\
\text { (Gosliner and Willan, 1991) }\end{array}$ & Bunaken, Siladen & 5-8 m; uncommon & see text and Table \\
\hline & & Flabellina rubrolineata (O'Donoghue, 1929) & Bunaken & $6 \mathrm{~m}$; rare & nothing published \\
\hline & Proctonotidae Gray, 1853 & $\begin{array}{l}\text { Janolus sp. } \\
\text { (sp. } 11 \text { Gosliner et al., 2015: 308) }\end{array}$ & Bunaken & $7 \mathrm{~m}$; rare & nothing published \\
\hline
\end{tabular}

a Abundance is classified as: abundant: $>40$, common 20-39, uncommon 4-19, rare 1-3 specimens. 


\subsection{Anaspidae (Sea Hares)}

Aplysiidae

Stylocheilus striatus from the Aplysiidae family was found near Bunaken. Since we did not find specimens of the Aplysia genus and there is a comprehensive review on secondary metabolites of these sea slugs [20] they have not been further discussed here. Additionally, for the same reason Dolabella metabolites like the famous dolastatin 10 (1) are not discussed [21]. The focus here is on the genus Stylocheilus. Even though the toxicity of sea hares has been known for a long time, it took until 1974 until the so-called ether-soluble toxin of S. longicauda was identified as an oily mixture consisting of aplysiatoxin (2) and debromoaplysiatoxin (3) (Figure 1) [22]. The toxicity of this mixture was determined in mice, i.e., $\mathrm{LD}_{100} 0.3 \mathrm{mg} / \mathrm{kg}$, ip mouse [23,24]. The toxins 2 and 3 were labile above $\mathrm{pH} 7$ and below $\mathrm{pH} 4$, due to a phenolic hydroxyl and the tertiary hydroxyl at $\mathrm{C}-3$. Altogether, including the artifacts ensuing from the experimental conditions, eight derivatives were isolated. The toxins $\mathbf{2}$ and $\mathbf{3}$ have later been isolated from the cyanobacterium L. majuscula which is a food source of S. longicauda [25] and a biosynthesis via a polyketide biosynthesis pathway is most likely. Both are potent protein kinase $\mathrm{C}$ (PKC) activators and research is ongoing to develop analogues as anticancer lead structures, based on their anti-proliferative activity, but removing any tumour-promoting activities [26].

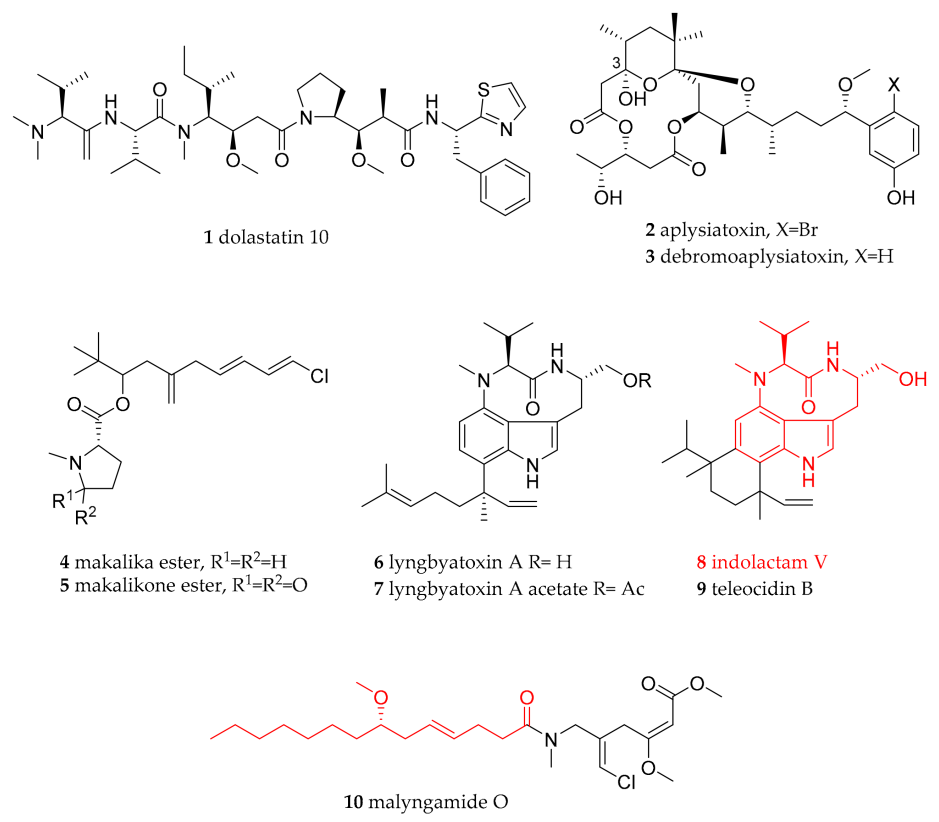

Figure 1. Biologically active natural products isolated from Stylocheilus species (including indolactam $\mathrm{V}$ and teleocin $\mathrm{B}$ for structure comparison).

A later study on S. longicauda from Hawaii revealed the chlorinated metabolites makalika ester (4) and makalikone ester (5) (Figure 1) [27]. Using high-resolution mass spectrometry the molecular formula of 4 was determined to be $\mathrm{C}_{19} \mathrm{H}_{30} \mathrm{ClNO}_{2}$, while 5 was carrying one additional $O$-atom, resulting in the molecular formula $\mathrm{C}_{19} \mathrm{H}_{28} \mathrm{ClNO}_{3}$. The structures were elucidated by NMR analysis and finally the stereochemistry of the $\mathrm{N}$-proline residue was determined by hydrolysis of the ester. Following purification of the amino acid, its optical rotation was measured and confirmed the stereochemistry by comparison with L-N-methylproline. Compound $\mathbf{5}$ showed moderate activity against the cancer cell lines P388, A549, and HTB38, i.e., $\mathrm{IC}_{50}$ in the range of $2.5-5 \mu \mathrm{g} / \mathrm{mL}$ [27]. The tert-butyl functionality present in $\mathbf{4}$ and $\mathbf{5}$ is uncommon in natural product chemistry; however, it has been identified before in isolates from the cyanobacteria L. majuscula and L. bouillonii [28-31]. A recurring feature in these molecules is the connection of the tert-butyl to the ester linkage and the 
$\mathrm{N}$-methyl via an oxymethine carbon [27]. This structural connection of the molecules is reflected in the connection of S. longicauda with L. majuscula, i.e., the sea slug is known to feed on the latter regardless of its toxic and unpalatable compounds produced. More compounds of cyanobacterial origin were found in Stylocheilus species in particular lyngbyatoxin A (6) and lyngbyatoxin A acetate (7) (Figure 1), as well as the malyngamides (Figure 1). The structure elucidation of 6 was first reported in detail from L. majuscula and its toxicity determined to mice $\left(\mathrm{LD}_{100}=0.3 \mathrm{mg} / \mathrm{kg}\right)$ and Poecilia vittata (baitfish), killing all fish within $30 \mathrm{~min}$ at $0.15 \mu \mathrm{g} / \mathrm{mL}$ [32]. Compound 6 also showed inflammatory activity and acts as a tumour-promoter [32]. The authors were able to deduce the structure of 6 using NMR by comparison to the reported values of the (-)-indolactam V (8) part of teleocidin B (9) a toxin produced by various Streptomyces species [32]. The biosynthetic genes for $\mathbf{6}$ and $\mathbf{9}$ have been identified revealing a mixed non-ribosomal peptide tepenoid biosynthesis [33,34]. The acetylated derivative 7 isolated from S. longicauda from Hawaii showed very potent toxicity with $\mathrm{IC}_{50}$ values against the cancer cell lines tested, i.e., $\mathrm{IC}_{50} 0.05 \mu \mathrm{g} / \mathrm{mL}$ [27].

In 2000, analysis of S. longicauda from Hawaii enlarged the arsenal of known malyngamides reported before from cyanobacterial species [32,35,36]. The malyngamide $\mathrm{O}(\mathbf{1 0})$ (Figure 1) was isolated from the freeze-dried sea slug, known to feed on L. majuscula. In 10, the typical $\mathrm{C}_{14}$ acid (in Figure 1 shown red) of malyngamides is linked to an acyclic amine. Toxicity tests of $\mathbf{1 0}$ with the cancer cell lines P388, A549, and HT29 gave values of $\mathrm{IC}_{50} 2 \mu \mathrm{g} / \mathrm{mL}$.

Other sea slugs also use L. majuscula as a food source, e.g., S. striatus, Bursatella, and the cephalaspidean Diniatys dentifer are described as grazers upon this toxic cyanobacterium. In certain tissues the levels of $\mathbf{3}$ and $\mathbf{6}$ reached high values indicating the bioaccumulation of these compounds in special tissues [37].

\subsection{Sacoglossa}

\subsubsection{Caliphyllidae}

Cyerce sp. 4 and sp. 2 (perhaps Cyerce bourbonica) were found at the BNP. No natural products have been reported from this species yet, but the $\alpha$ - and $\gamma$-pyrones cyercene A (11) and B (12) and 1-5 (13-17) (Figure 2) were isolated from Cyerce cristallina from the Mediterranean Sea and exhibited high ichthyotoxicity against Gambusia affinis, with cyercene A (11), cyercene-3 (15) and -4 (16) being very toxic $(10 \mu \mathrm{g} / \mathrm{mL})$. These metabolites are de novo synthesized by $C$. cristallina via the polypropionate pathway [2,38]. A possible role in ceratal growth was hypothesized, as well as a protective function against sunlight-induced damage. Further, the absence of $\alpha$ - and $\gamma$-pyrones from the family member Caliphylla mediterranea was reported. Chlorodesmin (18, Figure 2), a modified diterpene known from the green algae Chlorodesmis fastigiata was isolated from Cyerce nigricans obtained near Lizard Island (Australia) ([39] and references herein). Compound $\mathbf{1 8}$ has shown antibacterial and antifungal activity, but failed to show fish deterrent properties against Thalassoma lunare or a small wrasse species $[39,40]$.<smiles>[R]C(=CC(C)=CCC)c1oc(OC)c(C)c(=O)c1[R]</smiles>

11 cyercene $\mathrm{A}$ $\mathrm{R}_{1}=\mathrm{CH}_{3}, \mathrm{R}_{2}=\mathrm{CH}_{3}$ 12 cyercene $B$ $\mathrm{R}_{1}=\mathrm{H}, \mathrm{R}_{2}=\mathrm{H}$<smiles>[R3]C=C(C)C=C([R2])c1oc(=O)c(C)c(OC)c1[R]</smiles>

13 cyercene- $1 \mathrm{R}_{1}=\mathrm{H}, \mathrm{R}_{2}=\mathrm{H}, \mathrm{R}_{3}=\mathrm{CH}_{3}$ 14 cyercene- $2 \mathrm{R}_{1}=\mathrm{H}, \mathrm{R}_{2}=\mathrm{H}, \mathrm{R}_{3}=\mathrm{CH}_{2} \mathrm{CH}_{3}$ 15 cyercene- $3 \mathrm{R}_{1}=\mathrm{H}, \mathrm{R}_{2}=\mathrm{H}, \mathrm{R}_{3}=\mathrm{CH}\left(\mathrm{CH}_{3}\right)_{2}$ 16 cyercene- $4 \mathrm{R}_{1}=\mathrm{CH}_{3}, \mathrm{R}_{2}=\mathrm{CH}_{3}, \mathrm{R}_{3}=\mathrm{CH}_{3}$ 17 cyercene- $5 \mathrm{R}_{1}=\mathrm{CH}_{3}, \mathrm{R}_{2}=\mathrm{CH}_{3}, \mathrm{R}_{3}=\mathrm{CH}_{2} \mathrm{CH}_{3}$

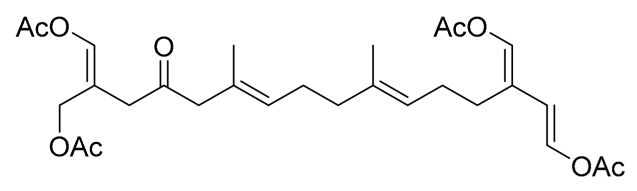

18 chlorodesmin

Figure 2. Bioactive compounds from Cyerce species. 


\subsubsection{Oxynoidae}

Lobiger sp. 1 and Lobiger viridis have been found at BNP. A detailed investigation of the defensive relationship between the green alga Caulerpa prolifera and three Sacoglossan predators showed that Lobiger serradifalci transformed the algal metabolite caulerpenyne (19) mainly to oxytoxin-1 (20), whereas another family member Oxynoe olivacea transformed it further and also contained also oxytoxin-2 (21) (Figure 3) [41]. Both compounds were deterrent against marine fishes and toxic against Gambusia affinis. Caulerpenyne is a known biotoxin from Caulerpa taxifolia, which affects several cellular and molecular targets and can cause neurological disorders [42,43].<smiles>CC(=O)O/C=C/C(=C\OC(C)=O)C(OC(C)=O)OC(C)=O</smiles>

19 caulerpenyne<smiles>CC(=O)O/C=C(/CC=O)[C@H](C/C=C(\C)C#CC=C(C)C)OC(C)=O</smiles>

20 oxytoxin-1<smiles>CC(=O)OC=C(CC(C=O)CC=O)[C@@H](CC=C(C)C#CC=C(C)C)OC(C)=O</smiles>

21 oxytoxin-2

Figure 3. Caulerpenyne and related metabolites from Oxynoidae mollusk.

\subsubsection{Plakobranchidae}

Elysia asbecki and at least 3 unidentified Elysia species were collected at BNP. Further, Thuridilla albopustulosa, Thuridilla flavomaculata, Thuridilla gracilis and Thuridilla lineolata were found.

To date, manifold chemical studies on Elysioidean species collected from distinct geographic areas from the Indo-Pacific Ocean to the Mediterranean Sea have been published [44-49]. A chemical marker for a selected group of Elysia sacoglossans including E. chlorotica and E. viridis are $\gamma$-pyrone polypropionates, which have been reported from different geographical areas in the world $[47,50]$. These polypropionates, e.g., elysione (22) are de novo biosynthesized by the slugs and might complement the photoprotective role of algal chloroplast pigments in a photolytic habitat, since the biosynthesis of these molecules is influenced by light irradiation, justifying preservation of this pathway in Elysoidean molluscs [47,50,51].

Algal derived sesquiterpenoids such as 19, 20 and 21 have also been found in several Elysia species, as well as the diterpenoid udoteal (23) with associated antibacterial and antifungal activity having been isolated from E. translucens $[3,40]$. The ability to chemically modify ingested algal terpenoids has also been reported from E. halimedae transforming the halimedatetracetate (24) to halimedatetracetate alcohol (25) (Figure 4) [52].

Most important, from a pharmacological point of view, was the isolation of dietary algal metabolites including a large family of structurally unrelated depsipeptides, called kahalalides, from E. rufescens, E. ornata, E. grandifolia and their algal diet Bryopsis pennata $[46,48]$. These cyclodepsipeptides exhibit highly diverse biological activities, such as antiviral, antifungal, antileishmanial, cytotoxic and immunosuppressive properties $[46,48,53,54]$. The most important representative is kahalalide $\mathrm{F}$ (26), which is the largest and most biologically active compound of these cyclic peptides $[46,48]$. Compound 26 occurs naturally as a mixture with its isomer isokahalalide F (27), which also shows interesting biological activities [55,56]. It was proposed that $\mathbf{2 6}$ and $\mathbf{2 7}$ might be of bacterial origin, with Mycoplasma spp. and Vibrio spp. as possible producers being the most abundant bacterial groups affiliated with E. rufescens and its mucus [57]. 
<smiles>CCCC(C)C(=O)/C=C(\C)C1C(C)=CC(C)=CC1c1oc(OC)c(C)c(=O)c1C</smiles>

23 udoteal $\mathrm{R}=\mathrm{CHO}, \mathrm{R}_{1}=\mathrm{H}$

24 halimedatetracetate $\mathrm{R}=\mathrm{CHO}, \mathrm{R}_{1}=\mathrm{H}$

25 halimedatetracetate alcohol $\mathrm{R}=\mathrm{CH}_{2} \mathrm{OH}, \mathrm{R}_{1}=\mathrm{OAc}$

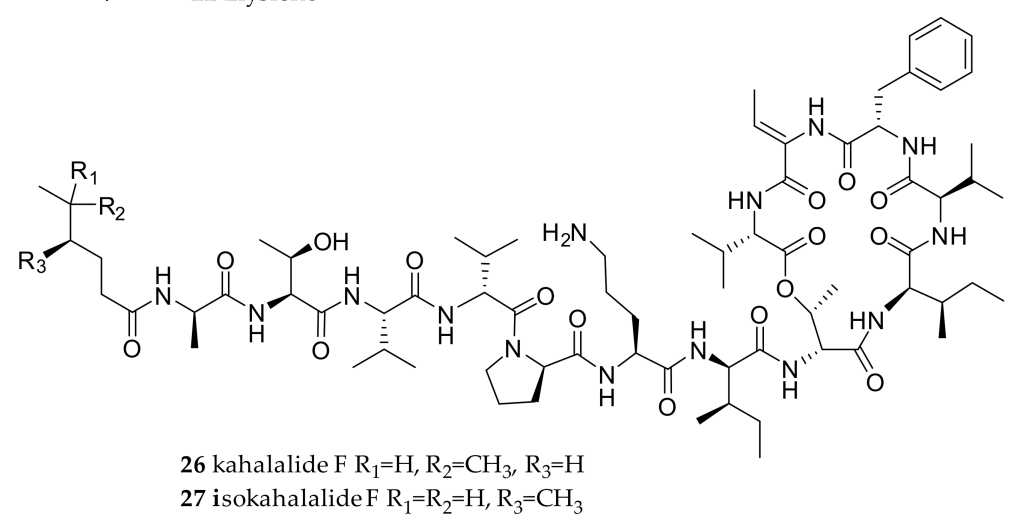

Figure 4. Bioactive compounds from Elysia species.

First reports from a Thuridilla species were performed in Italy on Thuridilla hopei [58]. Thereby, the diterpenoid thuridillins were isolated, possessing a central $\alpha, \beta$-epoxy- $\delta$-lactone ring which is substituted by an uncyclized or cyclized isoprenoid chain and a 2,5-diacetoxy-2,5-dihydrofuran unit. T. splendens from Australia yielded new thuridillins, together with thuridillin A (28, Figure 5) [59]. The separation of the various thuridillins was challenging, but thuridillin-related aldehydes isolated from a Mediterraneam T. hopei were even more unstable. The samples decomposed during NMR measurements using $\mathrm{CDCl}_{3}$ as solvent. Subsequent analysis in $\mathrm{C}_{6} \mathrm{D}_{6}$ was advantageous. Nor-thuridillonal (29) proved to be the epoxylactone (30, Figure 5) from the algae Pseudochlorodesmis furcellata [60]. It shows the same carbon scaffold and possesses significant feeding deterrent properties, thus was implicated as the precursor diterpene of the thuridillins in T. hopei.

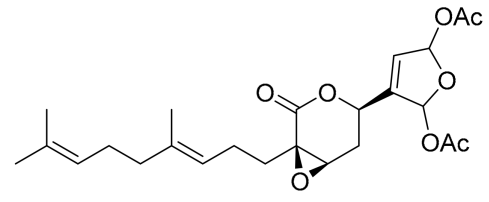<smiles>CC(=O)OCC/C(C=O)=C\C=C\C(=O)CC/C=C(\C)CCC=C(C)C</smiles>

29 nor-thuridillonal

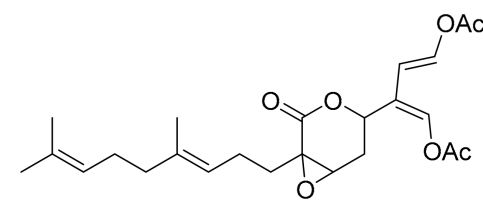

30 epoxylactone from $P$. furcellata, putative precursor of the thuridillins

Figure 5. Thuridillins and the related epoxylactone from Pseudochlorodesmis furcellata, a green algae (Chlorophyta).

\subsection{Cephalaspidea}

\subsubsection{Aglajidae}

At the BNP we found an as yet unidentified specimen belonging into the Aglajidae family as well as Chelidonura amoena, Chelidonura hirundinina and Odontoglaja guamensis. No bioactive compounds have reported for any of these species. However, bioactive compounds have been isolated from Philinopsis and Navanax species within the same family. 
Kulolide-1 (31, Figure 6), a cyclic depsipeptide with potent cytotoxicity and anti-tumour activity $(0.7 \mu \mathrm{g} / \mathrm{mL}$ against L-1210 and $2.1 \mu \mathrm{g} / \mathrm{mL}$ against P388 cell line) was isolated from an Hawaiean Philinopsis speciosa specimen [61]. Further, analysis of Hawaiian specimen revealed the presence of more peptides of the kulolide family such as kulolide-2 (32), kulolide-3 (33), kulokainalide-1 (34) and the unusual didepsipeptides kulokekahilide-1 (35) and kulokekahilide-2 (36, Figure 6) [62-64]. Moderate cytotoxicity was reported for 34 and 35 , but potent cytotoxicity as well as selective cytotoxicity for 36 (P388, SK-OV-3, MDA-MB-435, and A-10 with $\mathrm{IC}_{50}$ values of 4.2, 7.5, 14.6, and $59.1 \mathrm{nM}$, respectively, and the A-10 cell line not transformed). Additionally, the macrolide tolytoxin 23-acetate (37) was suspected to be responsible for some of the activity measured for 34 and related peptides [63]. Striking structural similarity between molecules from P. speciosa and from cyanobacteria implies that their biosynthetic origin lies in cyanobacteria and the molecules from the slugs are of dietary origin. The transfer is most likely mediated via herbivorous molluscs like the sea hares Stylocheilus longicauda and Dolabella auricularia which in turn were readily eaten by P. speciosa in a feeding experiment [63]. Furthermore, the same study confirmed the presence of $\mathbf{3 1}$ in S. longicauda. The capability of sea slugs to handle toxins produced by cyanobacteria is also shown by the fact that pitipeptolide A (38, Figure 6), a kulolide family depsipeptide produced by the cyanobacterium Lyngbya majuscula, was deterrent to various small invertebrates which usually can tolerate algal chemical defensive molecules; but it did not deter feeding of Stylocheilus striatus [65], which in turn can be prey for sea slugs of the Aglajidae family.<smiles>[R]CC[C@H](OC(=O)[C@H](C)NC(=O)[C@H](NC(=O)[C@@H]1CCCN1C(=O)[C@H](Cc1ccccc1)OC(=O)[C@@H](C(C)C)N(C)C(=O)[C@H](NC(=O)C(C)C)C(C)C)C(C)C)C(C)C</smiles>

31 kulolide- $1 \mathrm{R}=\widehat{\curvearrowright}$ 32 kulolide- $2 \mathrm{R}=\widehat{\curvearrowright}$ 33 kulolide- $3 \mathrm{R}=\widehat{\Upsilon}$

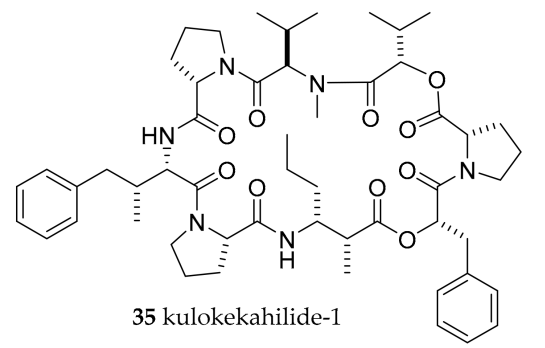

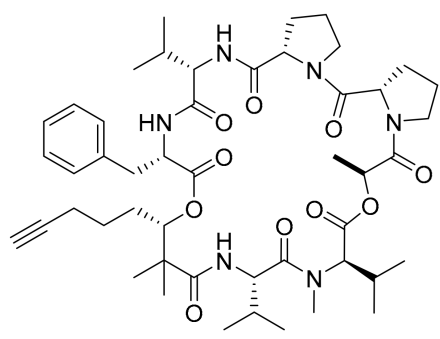

34 kulokainalide-1

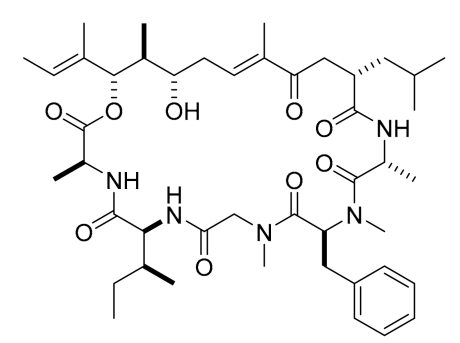

36 kulokekahilide-2

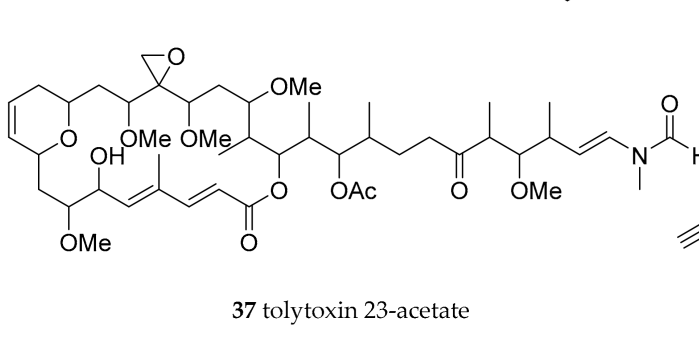

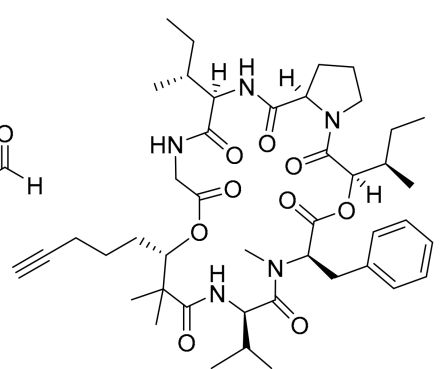

38 pitipeptolide A

Figure 6. Biologically active natural products from molluscs of the Aglajidae family and the cyanobacterial pitipeptolide A. 
The underlying biosynthetic pathway for the kulolide is most likely a non-ribosomal peptide synthetase, also incorporating unusual non-proteinogenic amino acids. The kulolide type molecules can be further subdivided into subgroups with distinct changes in biological activity [66].

Another member of the Aglajidae family, Navanax inermis is known to be a rich source of bioactive compounds. The first natural products found in Pacific N. inermis specimens were the navenones A-C (39-41) serving as pheromones [67]. Furthermore, the very ichthyotoxic isopulo'upone (42) and polypropionate 5,6-dehydroaglajne-3 (43) were found in Pacific specimen [68]. The toxic (Artemia salina $\mathrm{LD}_{50}<35 \mathrm{ppm}$ ) polypropionates aglajne-1 (44), aglajne-2 (45) and aglajne-3 (46) (Figure 7) were isolated from the Mediterranean family member $P$. depicta [69]. Compound 46 was also very ichthyotoxic against Gambusia affinis. P. depicta and N. inermis are carnivorous and feed on Bulla species. Again, a detailed investigation in compounds contained by prey and predator revealed a good relationship and suggest they are of dietary origin $[69,70]$.
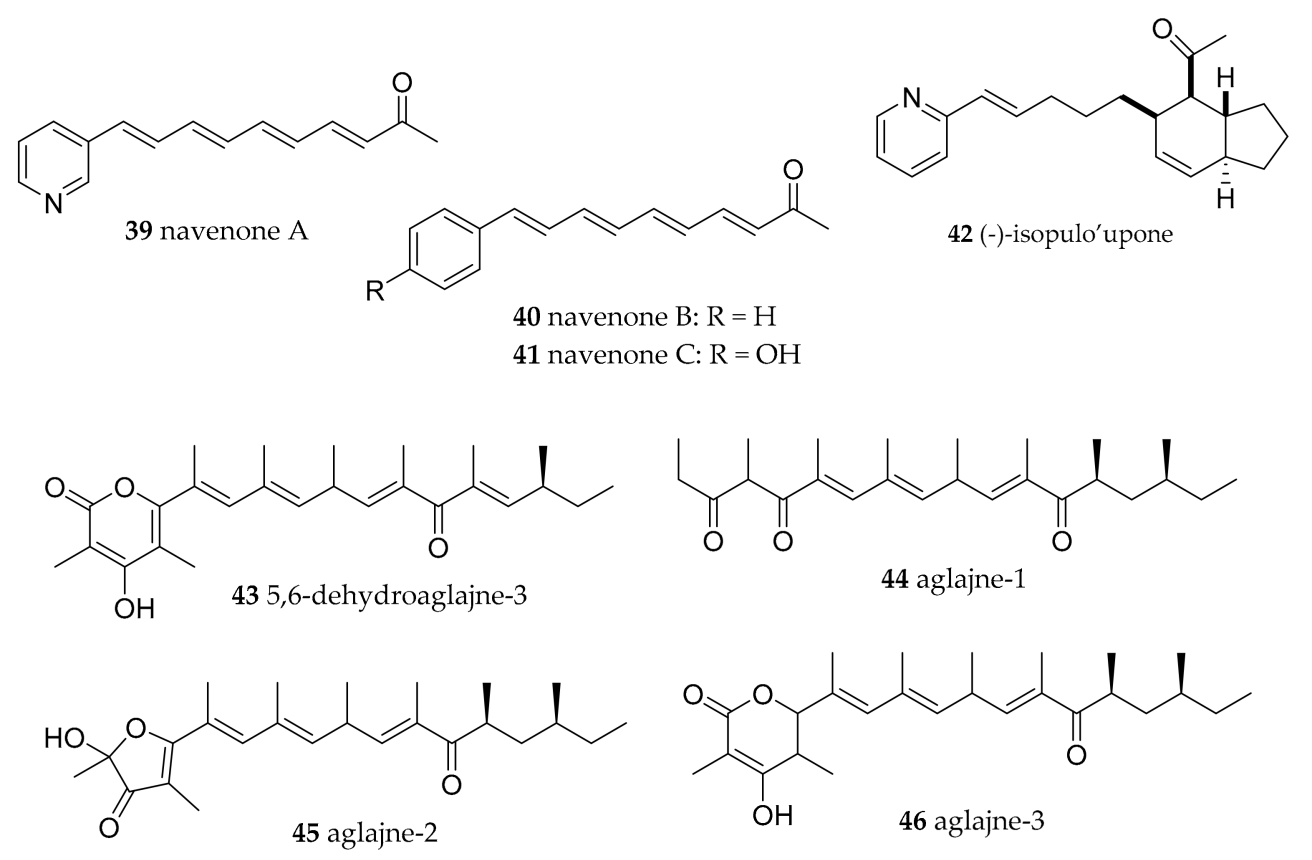

Figure 7. Further biologically active natural products from molluscs of the Aglajidae family.

\subsubsection{Gastropteridae}

Sagaminopteron psychedelicum, Siphopteron tigrinum, Siphopteron cf ladrones, Siphopteron brunneomarginatum, Siphopteron nigromarginatum and Siphopteron spec have been found at BNP. Until now, no natural products have been reported from Siphopteron species.

Sagaminopteron nigropunctatum and S. psychedelicum seemed to have chosen different strategies to repel or hide from predators. S. psychedelicum's phenotypic appearance is eye-catching. Such a warning coloration is typical for many opisthobranchs, which use chemical molecules to defend themselves. S. nigropunctatum instead is highly cryptic and hard to spot on the sponge these two species can be found on. Analysis of the natural products derived from these sea slugs revealed that both species possess polybrominated diphenyl ethers (BDEs), especially 3,5 dibromo-2- (2',4'-dibromo-phenoxy)phenol (47, Figure 8) which can also be found within their host sponge Dysidea granulosa [71]. Compound 47 was detected in the mantle of the slugs in the same concentration as in the sponge, e.g., $2-4 \%$. However, in the parapodia of the slugs the compounds showed a concentration of approximately $8-10 \%$, indicating that the sea slugs concentrate the BDEs in these appendages. Antifouling activity of 47 has been evaluated against marine bacteria, a diatom, barnacle larvae and mussel juveniles and found to be highly active, but non-toxic [72]. 


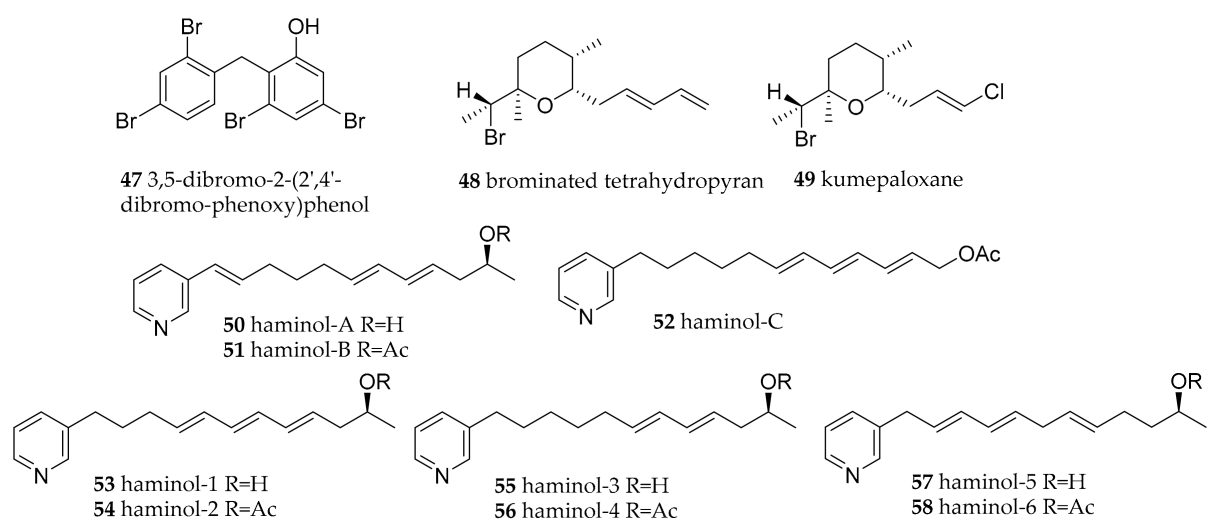

Figure 8. Bioactive metabolites from sea slugs of the Gastropteridae and Haminoidae families.

\subsubsection{Haminoeidae}

Two different species of Haminoea have been identified near Bunaken. In H. cyanomarginata from Greece, the brominated tetrahydropyran (48) was isolated [73], and was reported also in the congeneric species $H$. cymbalum from Indian coasts and stated to be previously isolated from an Australian sponge. It is structurally related to kumepaloxane (49) found in H. cymbalum from Guam [74]. Compound 48 proved to be highly toxic to the mosquito fish G. affinis at the concentration of $1 \mathrm{ppm}$ [73]. It also produced a strong food rejection in the generalist marine shrimp Palaemon elegans.

Haminoea species are known to contain 3-alkylpyridines named haminol A-C (50-52) and haminol 1-6 (53-58) (Figure 8) [75], which are similar to the navenones in Navanax species (see Figure 7). Haminols act as alarm pheromones and have been tested for antifouling properties; especially $\mathbf{5 4}$ showing good anti-settlement activity against larvae of the barnacle Amphibalanus amphitrite and low toxicity [76]. Feeding studies with labelled nicotinic acid methyl ester and acetate showed de novo synthesis of $\mathbf{5 4}$ in the Mediterranean mollusc H. orbignyana, suggesting nicotinic acid as an unusual PKS starter unit and the side chain polyketide derived [4]. However, these findings do not rule out that associated microorganisms are the actual producers.

Two polypropionates similar to 5,6-dehydroaglajne-3 (43), have also been isolated from the Mediterranean $H$. fusari after methylation together with the bioactive haminols (53-58), but no bioactivity has been examined [77].

\subsection{Pleurobranchomorpha}

\subsubsection{Pleurobranchidae}

Pleurobranchus forskalii was collected from BNP. The first cyclic peptide isolated from Pleurobranchus forskalii collected from Manado (the town vis-à-vis from Bunaken Island) was keenamide A (59) (Figure 9) [78]. This cytotoxic cyclic hexapeptide comprising of a thiazoline and an isoprene residue was tested against several tumor cell lines and showed $\mathrm{IC}_{50}$ values in the range from $2.5 \mu \mathrm{M}$ (against P388, A549, and MEL20) to $5 \mu \mathrm{M}$ (against HT29). A further macrocyclic peptide isolated from P. forskalii is cycloforskamide (60), a dodecapeptide (Figure 9) [79]. It was isolated by chromatography techniques and its molecular formula is $\mathrm{C}_{54} \mathrm{H}_{86} \mathrm{~N}_{12} \mathrm{O}_{11} \mathrm{~S}_{3}$ showing three thiazoline heterocycles. Using chiral-phase gas chromatography, the authors succeeded to deduce the absolute configuration. The presence of three D-amino acids point towards a non-ribosomal peptide synthetase (NRPS) system as the biosynthetic basis for this cyclic peptide. It might be diet or symbiont-derived. However, its similarity to cyanobactins also points towards cyanobacterial origin. Cyanobactins are an example of symbiont derived (ribosomally synthesised) cyclic peptides containing thiazoline moieties found in several sponges, but biosynthetic genes are encoded in symbiotic cyanobacteria [80]. The peptide 60 showed cytotoxicity against the murine leukemia cell-line P388 ( $\mathrm{IC}_{50}$ of $\left.5.8 \mu \mathrm{M}\right)$ 


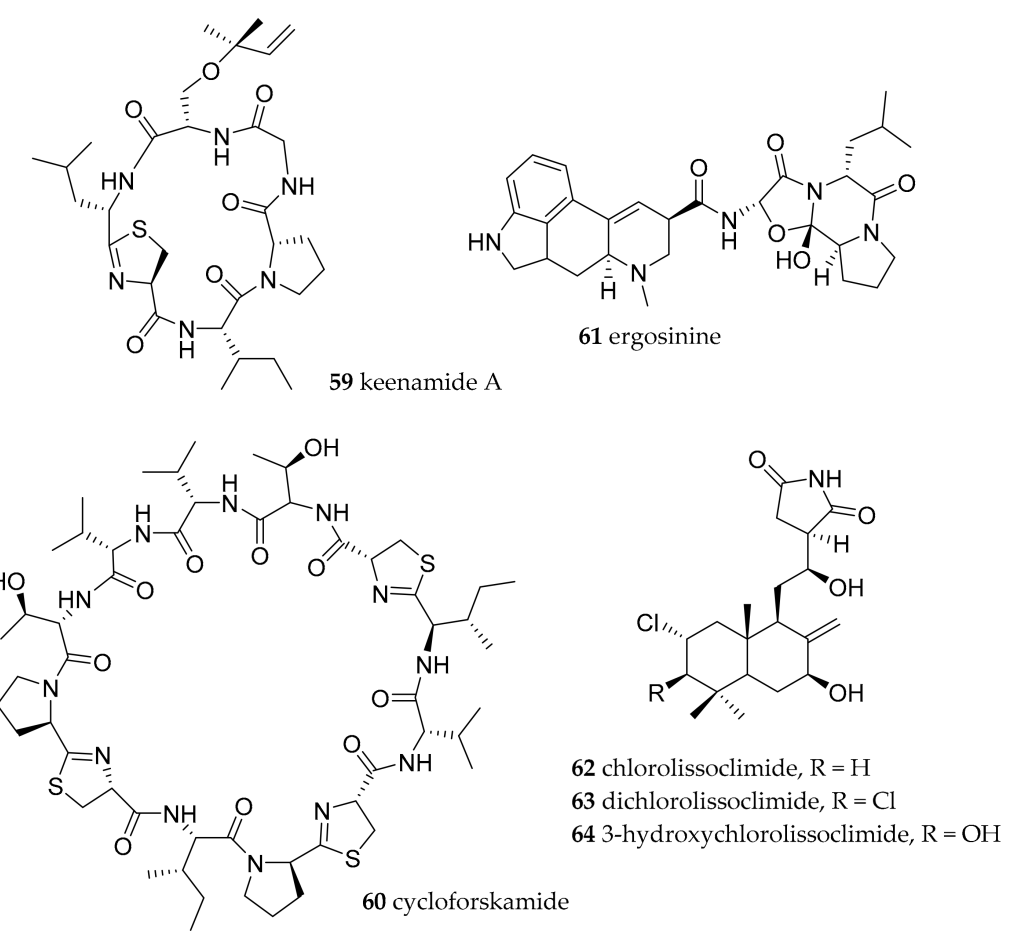

Figure 9. Biologically active natural products isolated from Pleurobranchus species.

Ergosinine (61) was isolated from P. forskalii collected from Ishigaki Island, Japan [81]. This was the first time such an alkaloid had been isolated from marine environments, which was until then only described from terrestrial higher plants and fungi. The authors speculate that this indicates the accumulation of ergopeptines in macroorganisms living in marine habitats around the coast. Toxic effects of ergot alkaloids are known since medieval times and caspase-3-activation have also been determined [82].

From the Pleurobranchus species P. albiguttatus and P. forskalii, collected in the Philippines, chlorinated diterpenes were isolated [83]. Similar diterpenes had been reported before from Lissoclinum species of the taxon Ascidiacea. This finding gave a direct hint towards the original source of the diterpenes to be the prey of Pleurobranchus. Chlorolissoclimide (62) and dichlorolissoclimide (63) were reported to be potent cytotoxins and $3 \beta$-hydroxychlorolissoclimide (64, Figure 9) exhibited solid tumor selectivity.

Bioassay-guided fractionation for protein synthesis inhibitors also yielded $\mathbf{6 2}$ and $\mathbf{6 3}$ as the active components [84]. The $\mathrm{IC}_{50}$ values determined for 62 and 63 were $0.7 \mu \mathrm{M}$ and $1.25 \mu \mathrm{M}$, respectively. An antibacterial effect was not detected. However, it was revealed that lissoclimides block translation elongation by inhibiting translocation, which results in an accumulation of ribosomes on mRNA.

\subsection{Nudibranchia}

The richest diversity among the Heterobranchs at BNP were found from the shell-less Nudibranchia families listed below.

\subsubsection{Aegiridae}

During the field trips around BNP only Notodoris serenae was found. No compound has been reported from this species yet. Naamidine A (65) as well as isonaamidine-A (66, Figure 10) have been isolated among 7 other imidazole alkaloids from the family member Notodoris citrina (Gulf of Eilat, The Red Sea), feeding on the sponge Leucetta chagosensis which also contained the compounds [85], indicating a dietary origin of the metabolites. No bioactivity of the compounds was evaluated at that 
time. Compound 65, later isolated from a Fijian Leucetta, was evaluated as selective inhibitor of the epidermal growth factor (EGF) and inhibited human tumour xenografts in mice [86]. Additionally, 65 from a Fijian L. chagosensis has antitumour activity and promotes caspase-dependent apoptosis in tumour cells [87]. Compound 66, isolated from the sponge L. chagosensis collected at French Polynesia, inhibits strongly the AI-2 channel of Vibrio harveyi, a marine pathogen and therefore acts as quorum sensing inhibitor [88]. Notodoris gardineri from Philippines contained the imidazole alkaloids 66 and dorimidazole-A (67, Figure 10), the latter exhibiting anthelminthic activity [89]. Clathridine (68, Figure 10), a sponge derived, cytotoxic imidazole alkaloid was found in samples of N. gardineri from the Great Barrier Reef and Papua New Guinea [90,91]. The biosynthetic origin of $\mathbf{6 8}$ is presumably the sponge Clathrina clathrus [92,93].
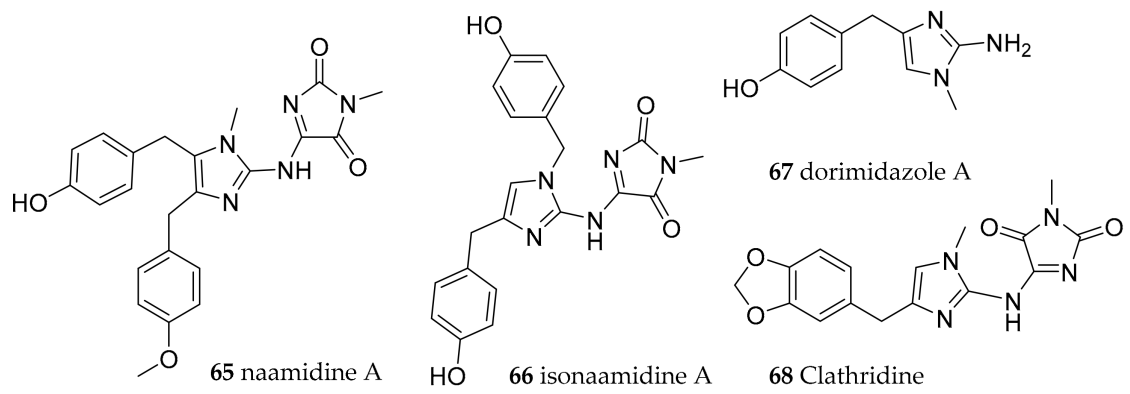

Figure 10. Biologically active natural products isolated from molluscs of the Aegiridae family.

\subsubsection{Chromodorididae}

\section{Ceratosoma}

A Ceratosoma sp. 2 has been found at BNP. No bioactive compounds have been reported from this species. However, a Ceratosoma amoena from the Great Barrier Reef was reported to contain allolaurinterol (69, Figure 11), which was also identified from the red algae Hymenena variolosa [94]. Since algae are not food of nudibranchs such as Ceratosoma, the authors suggest as explanation feeding of, e.g., Aplysia species upon the algae and transfer of the compound to their egg ribbons which are then eaten by the Ceratosoma [94]. Compound 69 isolated from Laurencia obtusa collected from the Caribbean island of Dominica was described to bear mild antibiotic, antifungal and anti-algal activity [95]. New investigations of 69 isolated from L. majuscula and L. venusta collected at Tanegashima Island also show good activity against antibiotic resistant bacteria [96]. (-)-Furodysinin (70, Figure 11) was the main sesquiterpene metabolite found in C. trilobatum and C. gracillimum, collected along the South China Sea coast and exhibited significant feeding-deterrent and ichthyotoxic properties. Compound $\mathbf{7 0}$ was also detected alongside the feeding deterrent nakafuran-9 (71, Figure 11) in C. gracillimum specimens from Hainan [97].
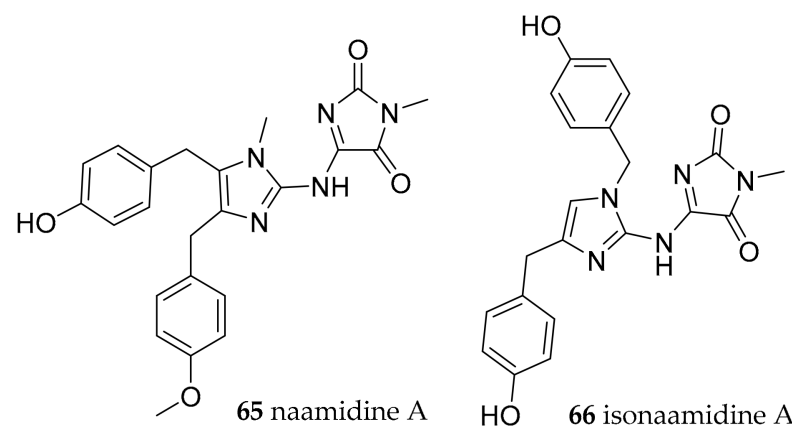<smiles>Cn1cc(Cc2ccc(O)cc2)nc1N</smiles><smiles>CN1C(=O)N=C(Nc2nc(Cc3ccc4c(c3)OCO4)cn2C)C1=O</smiles>

68 Clathridine

Figure 11. Bioactive metabolites from Ceratosoma species. 


\section{Chromodoris}

Around Bunaken Island we found specimens of Chromodoris annae, C. cf. boucheti, C. dianae, C. lochi, C. strigata and C. willani. From this Chromodoris species, only C. lochi and C. annae have been reported to contain bioactive compounds.

The cytotoxic and ichthyotoxic PKS-NRPS derived macrolide latrunculin A (72, Figure 12) was the first natural product discovered from C. lochi [98]. It was found by an investigation of Fiji specimens and their food source Spongia (=Cacospongia) mycofijiensis [98] which also contained these molecules, indicating a dietary origin. Lantrunculin A (72) and B (73, Figure 12) were first described from the Red Sea sponge Negombata magnifica [99] and were also found in other sponges such as Hyattela sp. as well as in C. hamiltoni from South Africa [100], C. elisabethina, C. magnifica, C. kuiteri, C. annae and C. quadricolor [101]. The latrunculins bear strong actin binding properties, thus interfering with the cytoskeleton and inhibiting the proliferation of cancer cells. Latrunculin B (73) additionally exhibited strong antifungal activity [102].

The PKS-NRPS derived mycothiazole (74, Figure 12) was found in C. lochi samples from Vanuatu and first reported with anthelmintic and toxic activities [103]. Compound 74 has also been found in sponges such as C. mycofijiensis [104] and shows selective cytotoxic activity, inhibits the hypoxia-inducible factor-1 (HIF-1) and suppresses mitochondrial respiration at complex I $[105,106]$. Analysis of $C$. lochi specimen from Indonesia revealed the presence of the sponge (again C. mycofijiensis) derived polyketides laulimalide (syn fijianolide B) (75, Figure 12) and isolaulimalide (syn fijianolide A) (76, Figure 12) [107]. Both exhibit cytotoxic activity by microtubule-stabilizing action but not at the same binding site as taxanes and are of interest as antitumor agents [108,109].<smiles>CC=CCC(C)=CC(=O)OC1CC(CCCC=CCC)OCC1(O)C1CSC(=O)N1</smiles>

72 latrunculin A

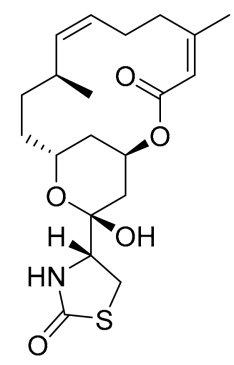

73 latrunculin B

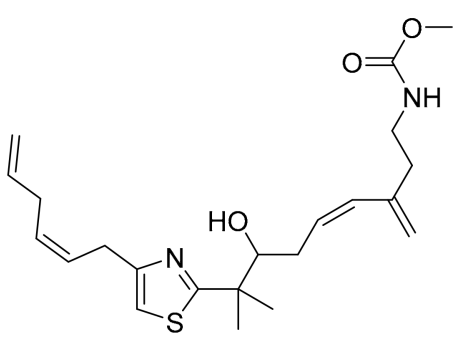

74 mycothiazole

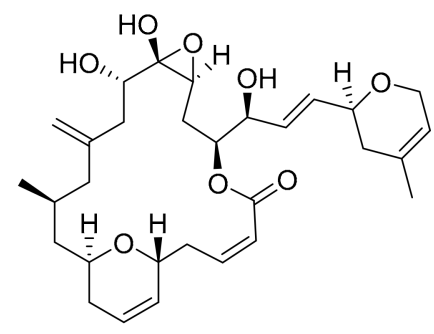

75 laulimalide

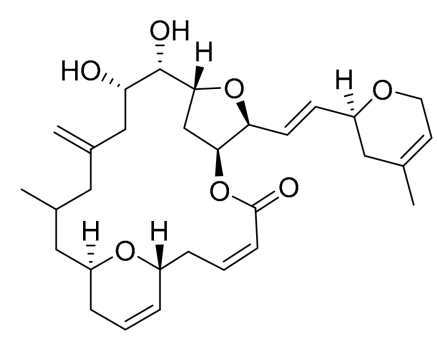

76 isolaulimalide

Figure 12. Bioactive metabolites from Chromodoris lochi.

Other species of the genus Chromodoris have been investigated and an intriguing diversity of compounds has been found, e.g., the investigation of Japanese Chromodoris inorata (accepted as Chromodoris aspersa) specimen revealed the presence of the sesquiterpenoids inorolide A (77), B (78) and C (79) (Figure 13) and a mixture of scalaranes. All inorolides were evaluated as being cytotoxic against murine lymphoma L1210 and epidermoid carcinoma KB cell lines [110]. 


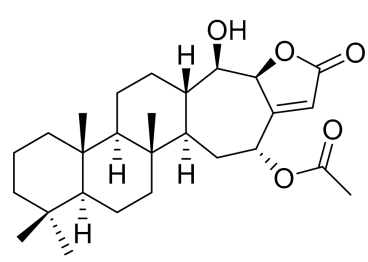

77 inorolide A

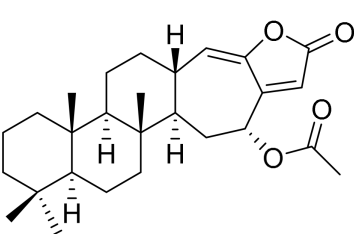

78 inorolide B

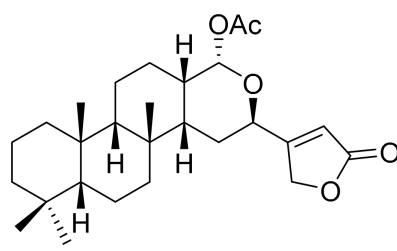

79 inorolide C

Figure 13. Bioactive metabolites from Chromodoris aspersa.

Analysis of Chromodoris luteorosea (accepted as Felimida luteorosea) from Spain revealed the presence of the ichthyotoxic diterpenes norrisolide (80), polyrhaphin C (81) and chelonaplysin C (82), luteorosin (83), as well as macfarlandin A (84) (Figure 14) and the closely related compounds [111]. Compound $\mathbf{8 0}$ has been found before in C. norrisi (accepted as Felimida norrisi) and in several sponges [111]. Chromodoris macfarlandi (accepted as Felimida macfarlandi, collected in California yielded a greater range of macfarlandines, i.e., macfarlandines A-E (84-88, Figure 14) [111-113]. Compound 88 proved to have unique Golgi-modifying properties that are different from the activities of norrisolide (80) [114]. Aplyroseol-2 (89, Figure 14), bearing cytotoxic activity was found in Chromodoris sinensis (accepted as Goniobranchus sinensis) from the South China Sea [97]. It was also found in Australian Chromodoris reticulata (accepted as Goniobranchus reticulatus) specimen together with other diterpenes [115].

The feeding deterrent nakafuran-9 (71, Figure 11) already mentioned from Ceratosoma gracillimum was also found in Hypselodoris maridadilus (as Chromodoris maridadilus) from Hawaii together with its related also feeding deterrent nakafuran-8 (90, Figure 14) [116]. Both were also present in the sponge that Dysidea fragilis, H. maridadilus feeds on [116].

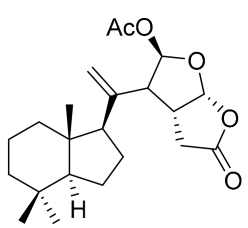

80 norrisolide

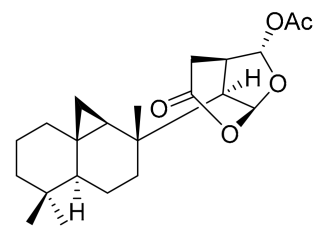

81 polyrhaphin

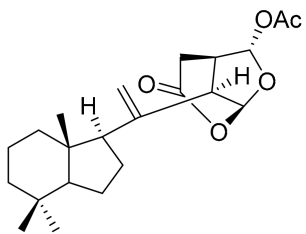

82 chelonaplysin $\mathrm{C}$<smiles>CC(=O)O[C@@H]1OC(=O)c2cc(CC3CCCC(C)(C)C3)c(C(C)=O)cc21</smiles>

83 luteorosin<smiles>[R2]C1([R2])OC(=O)c2ccc([C@@]3(C)CCCC(C)(C)C3)c(C(C)=O)c21</smiles>

84 macfarlandin $\mathrm{A}: \mathrm{R}_{1}=\mathrm{H} ; \mathrm{R}_{2}=\mathrm{OAc}$ 85 macfarlandin $\mathrm{B}: \mathrm{R}_{1}=\mathrm{OAc} ; \mathrm{R}_{2}=\mathrm{H}$<smiles>CC(=O)O[C@H]1O[C@@H]2OC(=O)C[C@H]2[C@H]1[C@]1(C)CC[C@H]2C(=CCC[C@@H]2C)[C@@H]1C</smiles>

86 macfarlandin C

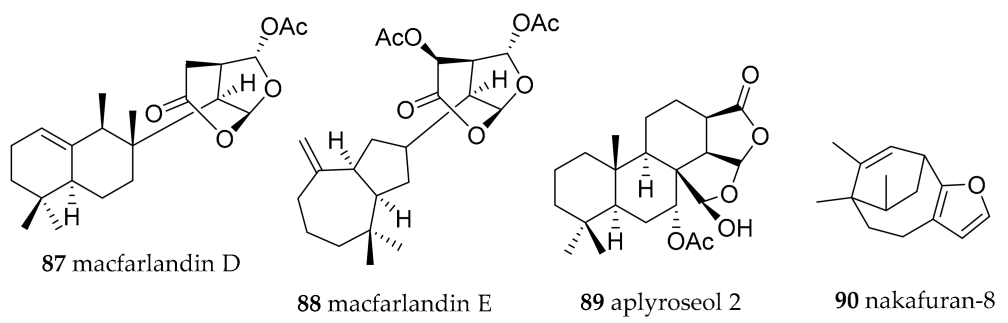

Figure 14. Further bioactive metabolites from Chromodoris species. 
Doriprismatica and Glossodoris

Specimens of Doriprismatica (=Glossodoris) stellata and Glossodoris (=Casella) cincta were found at BNP. None of these species has been chemically investigated so far. However, the closely related Doriprismatica atromarginata (as Glossodoris atromarginata) has been studied since 1982 [117-119], revealing many secondary metabolites of the furanoditerpenoid and scalarane type, and structural variants of these metabolites. These compounds are also found in several sponges and are therefore presumambly diet-derived, e.g., from the sponges Spongia sp. (former Hyatella intestinales), Hyrtios erectus and Hyrtios sp. [117,120,121]. Geographic variation between D. atromarginata from Sri Lanka and Australia, containing furanoditerpenes, and D. atromarginata from India, containing scalarane sesterterpenes has been described as a consequence of sponge prey [122]. These metabolites show various biological activities, such as cytotoxicity, antimicrobial activity, antiviral and antitumor activity, and ichthyotoxicity against G. affinis [122-126].

The most active compounds from $D$. atromarginata were spongiadiol (91) [123,127], spongiadiol diacetate (92) [128], epispongiadiol (93) [123,127,129,130], 12-deacetoxy-12-oxodeoxoscalarin (94) [120,124], heteronemin (95) [120,125,126,131], and mooloolabene D (96) (Figure 15) [122]. In addition to their cytotoxic activity, 91 and 93 showed antiviral, 94 ichthyotoxic and $\mathbf{9 5}$ antimicrobial activities.

Further investigation of Glossodoris dalli (accepted as Felimida dalli), Glossodoris sedna (accepted as Doriprismatica sedna) [132], Glossodoris rufomarginata [124], Glossodoris pallida, Glossodoris vespa and Glossodoris averni (accepted as Ardeadoris averni) [119] revealed a series of homoscalarane and scalarane compounds. Of the discovered compounds, 12-deacetyl-23-acetoxy-20-methyl-12-episcalaradial (97, Figure 15) showed ichthyotoxicity against G. affinis and moderate activity to inhibit mammalian phospholipase A2 [132].

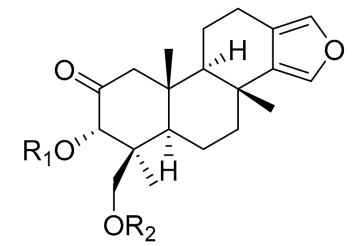

91 Spongiadiol $\mathrm{R}_{1}=\mathrm{H}, \mathrm{R}_{2}=\mathrm{Ac}$ 92 Spongiadiol diacetate $\mathrm{R}_{1}=\mathrm{Ac}, \mathrm{R}_{2}=\mathrm{Ac}$

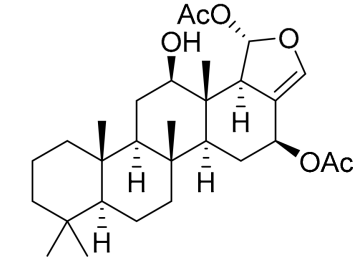

95 Heteronemin

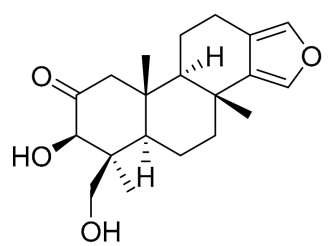

93 Epispongiadiol

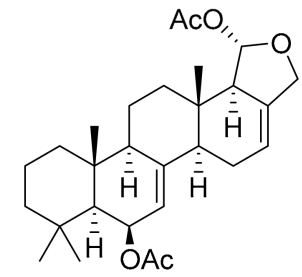

96 Mooloolabene D

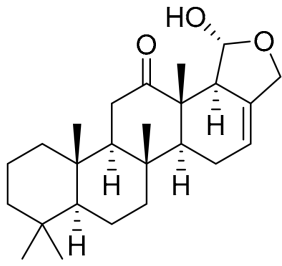

94 12-Deacetoxy-12-oxodeoxoscalarin

Figure 15. Bioactive metabolites from Glossodoris and Doriprismatica species.

\section{Goniobranchus}

Specimens of Goniobranchus geometricus and Goniobranchus reticulatus were found. However, no compounds are reported from these species so far. Goniobranchus species are known to contain spongian type cyclic diterpenes. This group of cytotoxic compounds is huge and only structural examples are shown in Figure 16. In Goniobranchus obsoletus (former Chromodoris obsoleta) for example dorisenones A (98), B (99), D (100), 11ß-hydroxyspongi-12-en-16-one (101), spongian-16-one (102) (Figure 16), together with related compounds were found and exhibited cytotoxicity as low as $\mathrm{IC}_{50}=0.2 \mu \mathrm{g} / \mathrm{mL}$ against murine lymphoma LI210 and human epidermoid carcinoma KB cells [133].

Alongside spongian-16-one (102), aplytandiene-3 (103), aplysulfurin (104) and aplyroseol-2 (89), gracilins, e.g., gracilin A (105), B (106), C (107), G (108), M (109) (Figure 16) were isolated from 
G.splendidus from Australia. All metabolites showed cytotoxic activity against Hela S3 cells [134]. Coumpound 106 and 107 and isomers showed activity against a wide panel of human tumor cell lines [135]. Again, gracilins are much better known from sponges such as Spongionella sp. than from Goniobranchus species and have been investigated as cyclosporine A mimics, as well as as BACE1 and ERK inhibitors. Hence, harbouring potential as antiinflammatory drug candidates, as well as potential in neurodegenerative diseases $[136,137]$.<smiles>[R8]C1C[C@H](C)[C@H](C)CCCC1(C)C</smiles>

98 dorisenone $\mathrm{A} \mathrm{R}_{1}=\mathrm{OAc}, \mathrm{R}_{2}=\mathrm{OH}$ 99 dorisenone $\mathrm{B} \mathrm{R}_{1}=\mathrm{H}, \mathrm{R}_{2}=\mathrm{OH}$ 100 dorisenone $\mathrm{D} \mathrm{R}_{1}=\mathrm{OAc}, \mathrm{R}_{2}=\mathrm{H}$ 101 11ß-hydroxyspongi- 12-en-16-one<smiles>CC1(C)CCC[C@@]2(C)C1CC=CC[C@@H]1[C@@H]3COC(=O)[C@@H]3CC[C@@H]12</smiles>

102Spongian-16-one

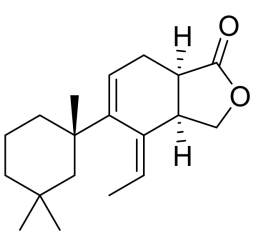

103 aplytandiene-3<smiles>CC(=O)O[C@H]1O[C@@H]2CC(=O)[C@H](C)c3c(ccc([C@@]4(C)CCCC(C)(C)C4)c32)[C@H]1C</smiles>

104 aplysulfurin

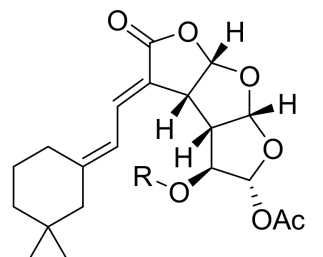

107 gracilin $C: R=A c$<smiles>C/C=C1\C([C@]2(C)CCCC(C)(C)C2)=CC[C@@H]2[C@@H]1[C@@H](OC(C)=O)O[C@@H]2OC(C)=O</smiles>

105 gracilin A

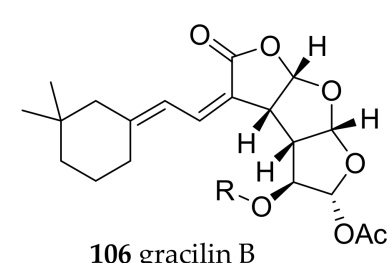

106 gracilin B

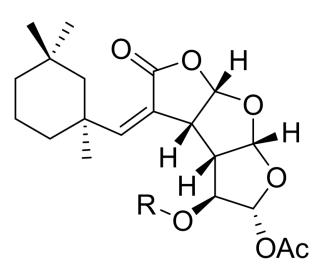

108 gracilin $\mathrm{G}: \mathrm{R}=\mathrm{Ac}$ 109 gracilin $\mathrm{M}: \mathrm{R}=\mathrm{COPr}$

Figure 16. Bioactive metabolites from Goniobranchus species.

\section{Hypselodoris}

Hypselodoris maculosa was found near Bunaken. No bioactive compounds are reported from this species, but Hypselodoris infucata from Kaneohe Bay, Oahu, Hawaii gave a 3:1 mixture of nakafuran-8 (90) and nakafuran-9 (71), in the same ratio as found in the prey sponge, Dysidea fragilis [116]. Minor metabolites previously isolated from the sponge were, however, not detected in the nudibranch extract in that study. Compounds $\mathbf{7 1}$ and $\mathbf{9 0}$ are reported as feeding deterrent, but did not show any antimicrobial activity when tested against E. coli, S. aureus, P. aeriginosa and B. subtilis in a disk diffusion assay [138]. Results from Hypselodoris maridadilus are already outlined above.

3.6.3. Cladobranchia (Families Arminidae, Dotidae, Eubranchidae, Facelinidae, Flabellinidae Proctonotidae)

Sea slugs from 6 families of the Cladobranchia clade have been collected from BNP. The chemical molecules of this clade have recently been reviewed and will not be repeated here [139]. An excellent work on the defense mechanism of Phyllodesmium has also recently been published and only the most bioactive compounds are mentioned below [1]. From the Arminidae family, Dermatobranchus striatus and two other different Dermatobranchus sp. were identified. No bioactive metabolites have been isolated from these species so far. From the family Dotidae, Doto sp., and from the family Eubranchidae 
Eubranchus sp. 4 have been found. From the family Facelinidae, Caloria indica, Favorinus japonicus, Favorinus mirabilis, Favorinus tsuruganus, Favorinus sp., two different species of Noumeaella sp. as well as Phyllodesmium briareum, Phyllodesmium poindimiei, Facelina rhodopos and Pteraeolidia semperi were identified. Cytotoxic briarane diterpenes such as brianthein $\mathrm{W}\left(\mathbf{1 1 0}, \mathrm{P}-388-\mathrm{ED}_{50} 0.76 \mu \mathrm{g} / \mathrm{mL}\right)$ and excavatolide C (111, P-388-ED $50.3 \mu \mathrm{g} / \mathrm{mL} ; \mathrm{KB}, \mathrm{A}-549$, HT-29-ED $\left.\mathrm{ED}_{50} 1.9 \mu \mathrm{g} / \mathrm{mL}\right)$ were isolated from P. briareum, and were also identified in its prey Briareum sp. (Octocorallia). Phyllodesmium magnum yielded several cembrane diterpenes including the cytotoxic 11-episinulariolide acetate (112) (P-388 ED $50-1.2 \mu \mathrm{g} / \mathrm{mL}, \mathrm{HT}-29 \mathrm{ED}_{50} 1.9 \mu \mathrm{g} / \mathrm{mL}, \mathrm{HL}-60 \mathrm{ED}_{50} 0.8 \mu \mathrm{g} / \mathrm{mL}$ ).

No bioactive compounds are reported for Noumeaella, Caloria and Favorinus species.

From the family Flabellinidae, several specimens of Flabellina bicolor, F. exoptata, F. rubrolineata were found at BNP. Additionally, at least four unidentified Flabellina species were collected.

Of these species, only the secondary metabolite content of F. exoptata was investigated [139]. A possible explanation for this low abundance of chemical defense molecules is that this Aeolidoidean molluscs, feeding upon hydrozoans, primarily use cleptocnides as their defense mechanism [140]. Chemical studies of F. exoptata, F. ischitana, F. pedata and F. affinis revealed that they contain homarine (113), which is frequently encountered in the Cladobranchia and their food sources. The biological function of $\mathbf{1 1 3}$ is, however, controversial [139,141].

From the family Proctonotidae, Janolus sp. (sp.11 Gosliner) was collected at BNP. The only literature of bioactive compounds from the nudibranch family Proctonotidae comes from a Mediterranean Janolus cristatus containing the toxic tripeptide janolusimide (114) (LD 5mg/kg; i.p. for mice) [139,142]. Until recently, no such tripeptides had been known from the food source of Janolus, but very recently, the $N$-methyl analogue janolusimide B (115, Figure 17) has been isolated from a New Zealand bryozoan Bugula flabellata [143].

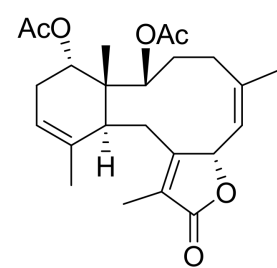

110 brianthein $\mathrm{W}$

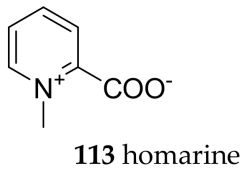

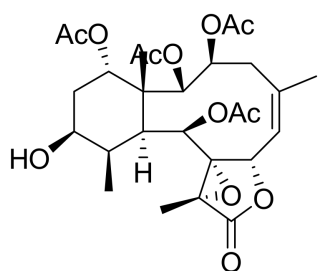

111 excavatolide C<smiles>[R]N(C)[C@@H](C)C(=O)N[C@@H](C)[C@@H](O)[C@@H](C)C(=O)N1C(=O)C(C)(C)C(=O)[C@H]1C</smiles>

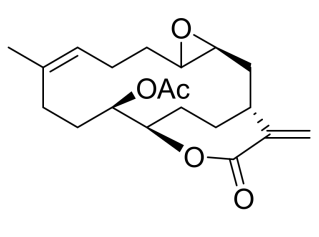

112 11-episinulariolide acetate

114 janolusimide: $\mathrm{R}=\mathrm{H}$

115 janolusimide $\mathrm{B}: \mathrm{R}=\mathrm{CH}_{3}$

Figure 17. Selected bioactive metabolites from Cladobranchia species.

\subsubsection{Dendrodorididae}

At BNP, specimens of Dendrodoris cf. fumata and Dendrodoris nigra were found. Extracts of the eggmasses of D. fumata showed antibacterial activity against E. coli, Staphylococcus aureus and Pseudomonas aeruginosa, indicating the use of chemical defence to protect early stage embryos against bacterial infection [144]. Chemical studies of D. nigra, D. carbunculosa as well as other Dendrodorids, have revealed the presence of many de novo synthesized sesquiterpenes of the drimane series, which can be considered a chemical marker of these nudibranchs [118,145-148].

Olepupuane (116) and polygodial (117) (Figure 18), a previously known feeding deterrent plant metabolite [149], have been isolated from different dendrodorid nudibranchs including Dendrodoris limbata [147]. Compound $\mathbf{1 1 7}$ exhibits antifeedant properties against marine and freshwater fish [150] and shows antifungal activity against Saccharomyces cerevisiae IFO 0203 and Hansenula anomala IFO 0136 [151]. However, 117 may not be originally present in the nudibranchs in a free state, due to its 
marked chemical reactivity towards primary amino groups [152], which could cause extensive damage to the nudibranch proteins. It was concluded that 116, de novo synthesized by dendrodorid slugs, is the easily stored, masked form of polygodial, which is transformed into the potent antifeedant when in contact with predators [152].<smiles>CC(=O)O[C@@H]1OC=C2[C@@H]1[C@@]1(C)CCCC(C)(C)[C@@H](OC(C)=O)C[C@@H]21</smiles>

116 olepupuane<smiles>CC1(C)CCC[C@]2(C)C1CC=C(C=O)[C@H]2C=O</smiles>

117 polygodial

Figure 18. Bioactive metabolites from Dendrodoris species.

\subsubsection{Discodorididae}

Taringa halgerda, Halgerda carlsoni and H. tessellata were collected at BNP. For none of these species bioactive natural products have been reported so far. An investigation of 5 Halgerda species from Australia and Japan, i.e., H. aurantiomaculata, H. gunessi, H. rubicunda, H. theobroma and H. willeyi showed that only H. aurantiomaculata contained tryptophane derivatives. Zooanemonin (118, Figure 19), was previously isolated from different marine sponges and the sea anemone Anemonia sulcate and was reported as antibacterial, whereas esmodil (119, Figure 19) first described as a synthetic compound, but also reported from the sponge Raspailia sp., has been described as a muscarinic agonist [153].

Paradoris indecora from Spain and Italy, former Discodoris indecora, has been described to contain furano sesterterpenes including variabilin (120, Figure 19) [154]. The latter was not toxic to G. affinis at $10 \mathrm{ppm}$, but active at a concentration of $300 \mu \mathrm{g} / \mathrm{cm}^{2}$ in an antifeeding assay using fresh water and marine fishes.<smiles>Cn1cc(CC(=O)[O-])c[n+]1C</smiles>

118 zooanemonin<smiles>C=C(C[N+](C)(C)C)OC</smiles>

119 esmodil<smiles>CC(=CCCC(C)C)CCC=C(C)CCCC(C)C=C1OC(=O)C(C)=C1O</smiles>

120 variabilin

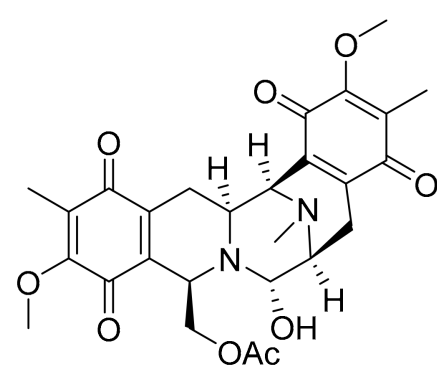

121 jorumycin

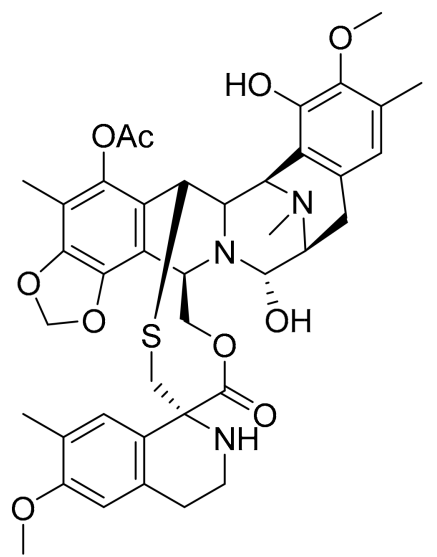

122 ecteinascidin 743

Figure 19. Bioactive metabolites from Discodoris species, ecteinascidin 743.

The most bioactive compound found in the family Discodorididae was first isolated from a Jorunna funebris collected of Mandapam (India). Jorumycin (121) is an isoquinolin alkaloid with antitumor activity of $\mathrm{IC}_{50}=12.5 \mathrm{ng} / \mathrm{mL}$ against cancer cell lines P388, A549, HT29 and MEL28 and 
has a saframycin-like structure similar to one of the most active marine-derived antitumor agents ecteinascidin 743 (122, Figure 19) isolated from the tunicate Ecteinascidia turbinata and an approved drug [155-157]. The development of ecteinascidin 743 as a drug shows clearly that overcoming the supply problem very often relies on bacteria, e.g., Pseudomonas fluorescens to produce a suitable precursor for synthesis of the final product [158].

\subsubsection{Hexabranchidae}

The family Hexabranchidae consist only of one genus consisting of two species. The egg mass of one of them, i.e., Hexabranchus sanguineus was collected at BNP. The first trisoxazole macrolides, i.e., ulapualide A (123) and B (124) (Figure 20) were isolated from egg masses of a Hawaiian H. sanguineus, [159] and from an unidentified nudibranch egg mass (kabiramide C, 125) from Kabira Bay, Ishigaki-jima Island, Japan [160]. The ulapualides were reported to inhibit proliferation of L1210 leukemia cells $\left(\mathrm{IC}_{50} 0.01-0.03 \mu \mathrm{g} / \mathrm{mL}\right.$ ) and the growth of Candida albicans, while $\mathbf{1 2 5}$ inhibited various fungi. Very recently, more ulapualides have been isolated and found to be less cytotoxic than $\mathbf{1 2 3}$ and 124 [161]. Halichondramides 126-129 and kabiramide A-E (125 for C and 130-133 Figure 20), isolated from $H$. sanguineus and the sponge Halichondria sp., were antifungal, cytotoxic and deterred Thalassoma lunare [162-164].

The trisoxazole macrolides bind to actin and can be regarded as a small molecule biomimetic of the gelsolin actin-binding proteins with drug lead potential—at least of the tail part of the molecule [165-168].

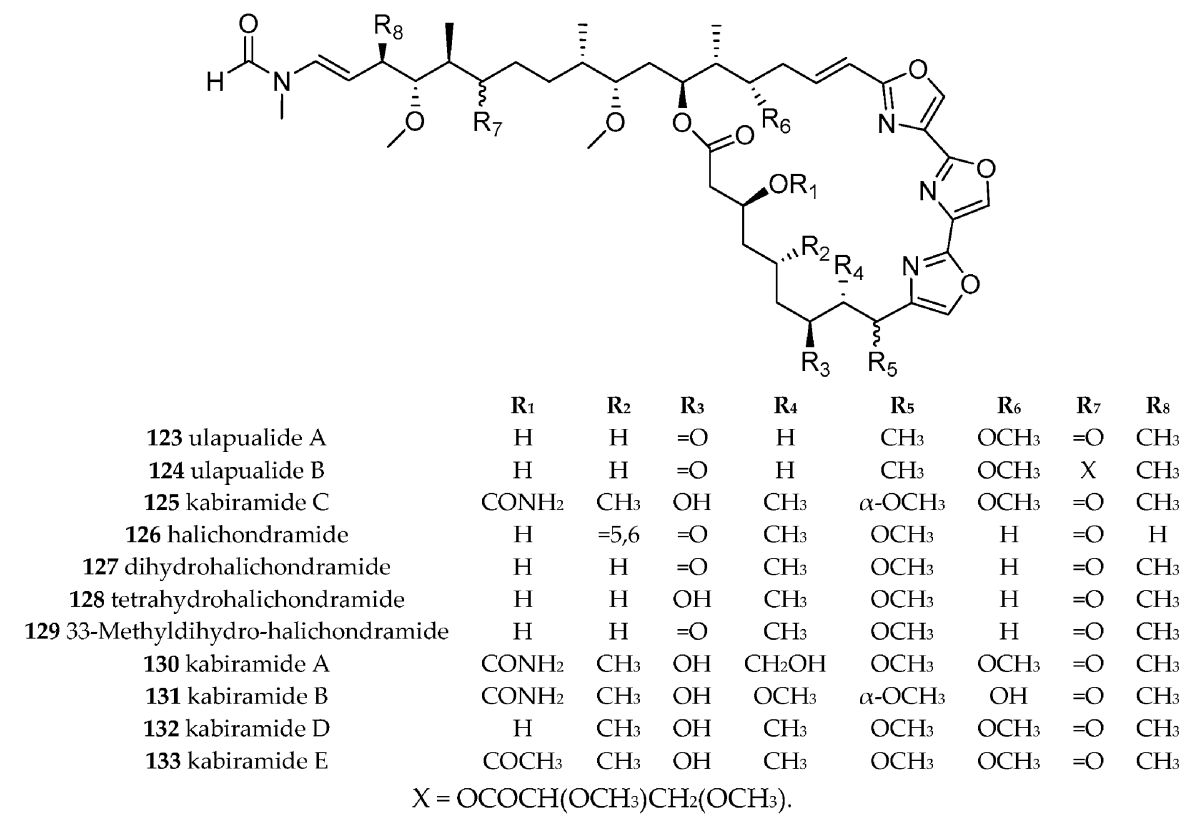

Figure 20. Kabiramides and halichodramides isolated from Hexabranchus sanguineus or its egg mass and from various sponges.

H. sanguineus seems to be the only nudibranch source of trisoxazole macrolides, but more than 30 highly similar trisoxazole macrolide have been isolated from different sponges, e.g., from the genera Halichondria, Mycale, Jaspis and Pachastrissa [160,165-167,169]. Some of them are reported to be a food source of $H$. sanguineus, and given the choice, $H$. sanguineus fed only on trisoxazole containing Halichondria and not on other sponges [162]. The intriguing structure of the trisoxazole macrolides is presumably of hybrid polyketide-non-ribosomal peptide biosynthesis. The producer is most likely an as yet unidentified microorganism, suggested by comparison with other actin binding macrolides such as luminaolide (first isolated from a red algae with its biosynthesis genes discovered in a cyanobacteria) [170]. Various total syntheses of marine macrolides including the trisoxazole 
macrolides are reported and reviewed by Yeung and Paterson [171] whereas the focus for chemical synthesis is nowadays on the bioactive tail part $[168,172]$.

\subsubsection{Phyllidiidae}

In the family Phyllidiidae, more than 49 species are found, which live in most parts of the Indo-Pacific. Intensive phylogenetic analysis to assist identification has been conducted using morphological and molecular data of 99 specimens (16 species) from Indonesian waters (West Papua, Gam, Kri, Mansuar, Batanta, Halmahera, Ternate) [173]. Species like Phyllidiella pustulosa yielded several subclades whereas molecular marker confirmed morphologically variable species like P. elegans and P. varicosa to be correct concerning the species boundaries [173]. Extensive chemical investigations of some species have been reported and focus on isocyanide substituted terpenes [174]. For sponges it was shown, that such an isonitrile function originates from inorganic cyanide. The terpenes possess various carbon skeletons, e.g., amorphane, pupukeanane, bisabolane. They are most probably derived from the sponge diet of the slugs and serve as defense chemicals against predators. Isocyanides also have antifouling activity, since they inhibited the settlement of barnacles [175]. From field trips in the BNP Phyllidia coelestis, Phyllidia elegans, Phyllidia ocellata, Phyllidia varicosa, Phyllidiella annulata, Phyllidiella pustulosa, Phyllidiella cf. lizae, Phyllidiella striata, Phyllidiopsis pipeki and Phyllidiopsis sphingis were found.

Phyllidia elegans, Phyllidiella annulata, Phyllidiella cf. lizae as well as Phyllidiopsis species have not been investigated yet concerning their secondary metabolites. The ethyl acetate extract of P. elegans from Guam was feeding deterrent towards reef fish, but no secondary metabolites were reported [174].

Phyllidia coelestis from Koh-Ha Islets, Krabi Province, Thailand, was recently reported to contain 1-formamido-10-(1,2)-abeopupukeanane (134, Figure 22), an unprecedented sesquiterpene with a rearranged and brigded carbon skeleton. Its structure was deduced based on extensive NMR data, but also X-ray analysis. It is structurally similar to 2-formamidopupukeanane (135), which was also reported in this study from $P$. coelestis. The formamide moiety in these compounds is most probably derived from an original isonitrile function [176]. Compounds $\mathbf{1 3 4}$ and $\mathbf{1 3 5}$ have cytotoxic properties towards cancer cells in the range of $0.05-10 \mu \mathrm{M}$ [177]. P. coelestis was also investigated for its lipid classes and fatty acid composition revealing unusual fatty acids, e.g., very long chain fatty acids [178].

Two reports target the secondary metabolite chemistry of $P$. ocellata. The sponge Acanthella cf. cavernosa from Hachijo-jima Island in Japan and P. ocellata, which most likely preyed upon this sponge, were investigated. Most secondary metabolites of the sponge were also found in the slug, i.e., cavernothiocyanate (136), 10 $\alpha$-isocyano-4-amorphene (137), axisonitrile-3 (138), and 7-isocyano-7,8-dihydro- $\alpha$-bisabolene (139, Figure 22) [179]. P. ocellata from Australian waters yielded sesquiterpenes also with isonitrile and isothiocyanate groups, however with different carbon skeletons as compared to the Japanese samples, e.g., 2-isocyanoclovene (140) and its dihydro analogue 2-isocyanoclovane (141), 1-isothiocyanatoepicaryolane (142) and 4,5-epi-10-isocyanoisodauc-6-ene (143, Figure 22). In vitro antimalarial activity tested for 140-143 was traced back to the isocyano functionality in the metabolites with $\mathrm{IC}_{50}$ values of $0.26-0.30 \mu \mathrm{M}$ for 140,141 and 143 vs. $>10 \mu \mathrm{M}$ for 142 [180].

P. varicosa seems to display much variability concerning its coloration, and P. varicosa and P. arabica are regarded as synonyms. In part, this taxonomic uncertainty can be traced back to alterations during preservation with regard to colour [181].

P. varicosa extracts (collected from Palau) deterred feeding by fish [174], and early observations reported that secretions from $P$. varicosa were lethal to fish and crustaceans. The toxic principle was already described in 1975 as a tricyclic sesquiterpene isocyanide, which at the time had a novel rearranged isoprenoid skeleton. According to the location of collection, i.e., Pupukea (Oahu, Hawaii) the compound was called 9-isocyanopupukeanane (144). The compound was also detected in the sponge Ciocalypta sp. (ex. Hymeniacidon sp.) on which P. varicosa was feeding [182]. Later, also 2-isocyanopupukeanane (145, Figure 21) was identified in P. varicosa from the same location [183]. 
In Japanese waters Phyllidiella rosans (former name Phyllidia bourguini) also yielded 144 [184]. From a Sri Lankan sample of $P$. varicosa the bisabolene type 3-isocyanotheonellin (146, Figure 21) with antifouling properties was obtained [185].

P. varicosa and the sponge Axinyssa cf. aculeata on which it preyed were obtained from reefs of Pramuka Island, Thousand Islands National Park, Indonesia. The nudibranch is one of the most abundant slugs in this National Park of Indonesia. Sponge and nudibranch contained epimeric 9-thiocyanatopupekeanane sesquiterpenes $(\mathbf{1 4 7}, \mathbf{1 4 8}$, Figure 21$)$ which were determined to be toxic to brine shrimp ( $\left.\mathrm{LC}_{50} 5 \mathrm{ppm}\right)$ together with $\mathbf{1 4 4}$ [186].

Phyllidiella pustulosa is quite well investigated today. In a biosynthetic study addressing the origin of the isocyanide and isothiocyanate functionality in axisonitrile-3 (138) and axisothiocyanate-3 (149) (Figure 22), metabolites of the sponge Acanthella cavernosa, also P. pustulosa, which fed on this sponge, was investigated. Using ${ }^{14} \mathrm{C}$-labelled potassium cyanide the sponge metabolites were ${ }^{14} \mathrm{C}$ enriched and subsequently, the labeled terpenes could be found in the nudibranch [176].

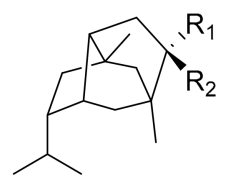

144 9-isocyanopupukeanane $\mathrm{R}_{1}=\mathrm{NC}, \mathrm{R}_{2}=\mathrm{H}$ 147 9-thiocyanatopupekeanane $\mathrm{R}_{1}=\mathrm{SCN}, \mathrm{R}_{2}=\mathrm{H}$ 148 9-thiocyanatopupekeanane $\mathrm{R}_{1}=\mathrm{H}, \mathrm{R}_{2}=\mathrm{SCN}$

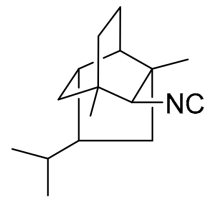

145 2-isocyanopupukeanane

ne 1463 -isocyanotheonellin

Figure 21. Bioactive sesquiterpenes from Phyllidia varicosa.

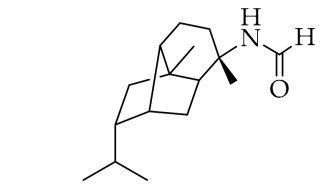

134 1-formamido-10(1,2)abeopupukeanane

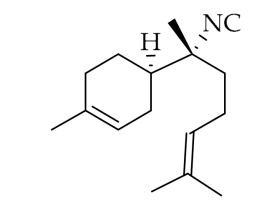

139 7-isocyano-7,8dihydro- $\alpha$-bisabolene

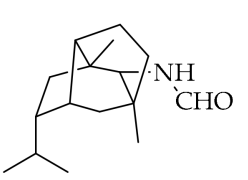

135 2-formamido pupukeanane

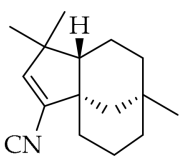

140 2-isocyanoclovene

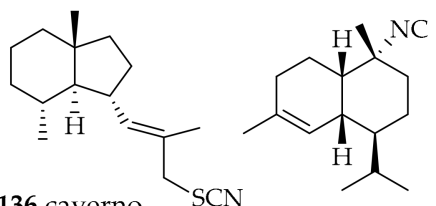

cavernothiocyanate

$13710 \alpha$-isocyano- 138 axisonitrile- $3 \mathrm{R}=\mathrm{CN}$ 4-amorphene 124 axisothiocyanate-3 R=NCS

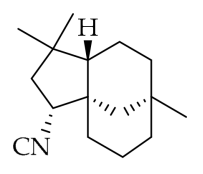

141 2-isocyanoclovane
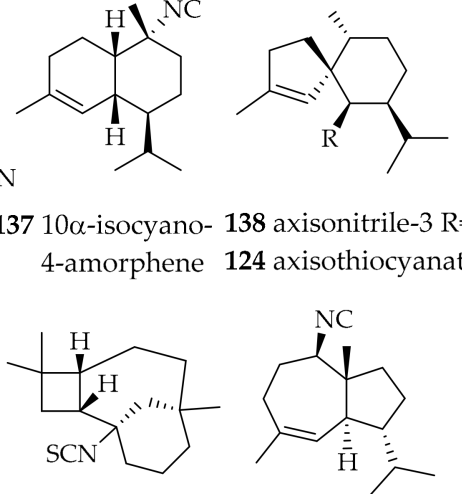

142 1-isothiocyanato 143 4,5-epi-10-isocyanoepicaryolane isodauc-6-ene

Figure 22. Bioactive sesquiterpenes from Phyllidia species.

P. pustulosa from Nananu-I-Ra reef, Fiji, presumably feeds on the sponge Phakellia carduus as judged from the very similar secondary metabolites present in the both samples. Apart from 138 (Figure 22), 10-isothiocyano-4-cadinene (150, Figure 23) with moderate antiplasmodial activity was reported [187]. This structure, however was questioned, based on a synthetic approach, and it was suspected that Wright had instead isolated 10-thiocyanato-4-cadinene (151, Figure 23), i.e., with a thiocyanate in place of the isothiocyanate [188]. The latter study demonstrated that the structure determination of such compounds is a major challenge.

In Chinese samples (Hainan Island, South China Sea) of P. pustulosa di- and sesquiterpenes were found. The diterpenes amphilectene (152), kalihinol-A (153), kalihinol-E (154) (Figure 23) were before reported from sponges, and the sesquiterpene named ent-stylotelline was the enantiomer of the sponge metabolite stylotellin. Compound 146 (Figure 21) was also found here, as above 
described for $P$. varicosa. The number of different and intriguing carbon frame works in this sample is astonishing. Feeding-deterrence tests against goldfish (Carassius auratus) revealed 152-154 to be active at $50 \mu \mathrm{g} / \mathrm{cm}^{2}$ [175].

From the coasts of Vietnam P. pustulosa yielded several sesquiterpenes, including 144, its C9-epi isomer and several sterols and ketosteroids. Based on the terpenes obtained the authors concluded that the mollusk feeds on sponges of the genera Acanthella, Halichondria, Axinella and Axinyssa [189]. P. pustulosa collected at Kin Bay, Okinawa, yielded 138, substituted axinisothiocyanate K derivative, and a new molecule (155) (Figure 23) with an isocyano group. The compounds were found to be moderately cytotoxic [190].

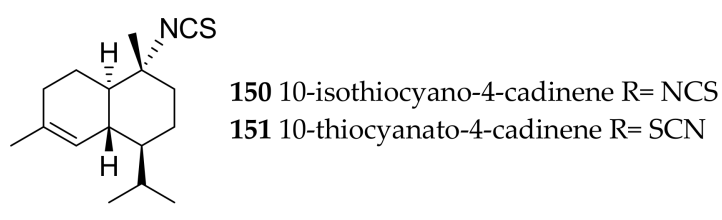

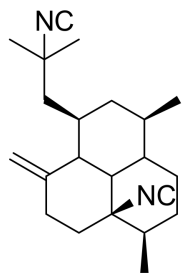

152 amphilectene

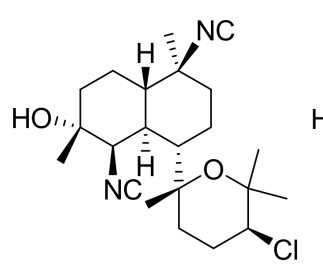

153 kalihinol-A

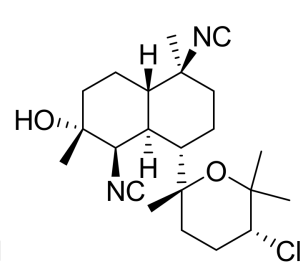

154 kalihinol-E

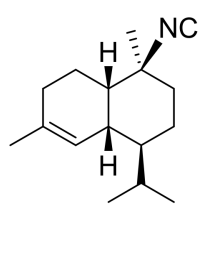

155

Figure 23. Bioactive sesquiterpenes from Phyllidiella pustulosa.

\subsubsection{Polyceridae}

From the family Polyceridae we collected Nembrotha cristata, Nembrotha kubaryana, Kaloplocamus dokte, Polycera japonica and Polycera risbeci during the field trips at BNP. No compounds are reported for the genus Kaloplocamus yet. The genus Tambja in the subfamily Nembrothinae gave the name to the tambjamines, and field and lab observations with species collected at the West coast of America clearly established that $\mathrm{T}$. abdere and T. eliora favored the tambjamine containing bryozoan Sessibugula translucens rather than, e.g., Bugula neritida as a food source. In turn, they were eaten by Roboastra tigris, also a sea slug of the Polyceridae family [191]. Nembrotha species collected in Micronesia have also been found to contain the presumably diet derived tambjamines A (156), C (157), E (158), F (159) the tambjamine aldehyde (160) and the blue tetrapyrrol (161) which were also found in the slugs prey the ascidian Atapozoa sp. [138,192]. From Nembrotha cristata from Ant Atoll the ratio of 156:157:158:159:160 was 39:39:5.5:11:5.5. From Nembrotha kubaryana from Sumilon Island, Philippines the ratio of 157:158:161 was 30.8:30.8:38.4 and from Nembrotha sp. from Apo Islands, Philippines 157:158:159:160 was 11.8:47:5.9:35.3. The crude extracts, mixtures of tambjamines, 157, 159 and 161 were all significant feeding deterrents at or below natural concentrations. The tambjamines 156 and 158 were not deterrent when tested alone at natural concentrations [192]. Compound 161 was found to be a potent antimicrobial agent; active against Bacillus subtilus at $5 \mu \mathrm{g} /$ disc [138].

No bioactive metabolites are reported for the two Polycera species, but Polycera atra MacFarland, 1905, which feeds on the byozoan Bugula neritina, contains bryostatins in its body and egg masses [193-195].

Bryostatins are a group of 20 polyketide macrolides with bryostatin 1 (162, Figure 24) investigated in over 20 clinical trials for treatment of cancer and Alzheimers disease. The true producer is an uncultured symbiotic bacterium Candidatus endobugula sertula and the biosynthesis genes of this polyketide have been discovered [196]. 


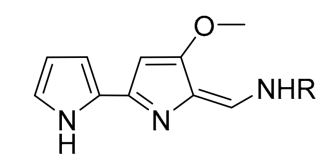

156 tambjamine A $\mathrm{R}=\mathrm{H}$ 157 tambjamine $\mathrm{C} \mathrm{R}=\mathrm{CH}_{2} \mathrm{CH}\left(\mathrm{CH}_{3}\right)$ 158 tambjamine $\mathrm{E} \mathrm{R}=\mathrm{CH}_{2} \mathrm{CH}_{3}$ 159 tambjamine $\mathrm{F} \mathrm{R}=$

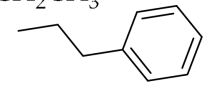

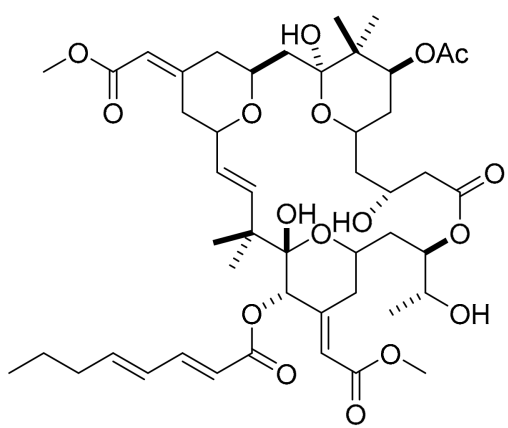

162 bryostatin 1

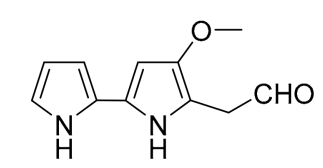

160 tambjamine aldehyde

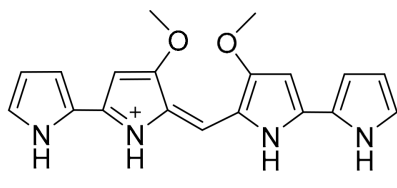

161 tetrapyrrole

Figure 24. Biologically active natural products isolated from sea slugs of the family Polyceridae.

\section{Discussion and Conclusions}

It can be seen that many compounds isolated from heterobranchs are most likely produced by invertebrate associated bacteria or cyanobacteria and Ciavatta concludes: "Noteworthy, the "mollusk-derived" metabolites that entered or that are in clinical trials are actually produced by microbes" [197]. However, the sea slugs themselves represent a great opportunity to screen for natural compounds with biological activity. It seems that evolution directed the sequestration of metabolites from the food source in a way that compounds providing a benefit for the sea slug, e.g., protection due to the fact that the metabolite has repellent activity against predators, are enriched. As a consequence, it is much easier to detect compounds with promising biological activities from the sea slugs, even though they do not represent the primary producer. Further research is needed to reveal the true producer of a bioactive compound, which is expected to be often a microorganism associated with the prey. Hence, the isolation of compound-producing microorganisms might be an approach to solve the supply issue [198]. Even if the true producer is not yet culturable, a metagenomic toolbox is available to discover the biosynthetic gene cluster corresponding to the natural product of interest and using it for heterologous expression approaches [199]. Securing the supply will facilitate comprehensive analysis and testing in the lab, which is a precondition for translational research, once natural products enter drug development phase.

From the huge biodiversity of sea slugs found around Bunaken Island, only a minority of species (14 out of 73) has been investigated chemically so far with only three from Indonesia (Tables 1 and 2). Here, Pleurobranchus forskalii and Chromodoris lochi show a diversity of highly bioactive chemically not related compounds, which are dietary derived and some are presumably of microbial origin. Looking then at the family level of the Chromodorididae (a very specious family) with 12 species found at BNP, the literature shows 41 bioactive compounds reported from 26 species worldwide with terpenoids dominating (see Table 2), but only C. lochi is included from the species collected at BNP. Because the sea slugs can usually shift to another food source if necessary, it is hard to determine a chemical marker for Chromodorididae. However, since this family is a proven rich source of bioactive compounds and many species are still under-investigated, it can be concluded that the chance to detect further interesting compounds is high.

For upcoming screening approaches, a valid dereplication strategy must be employed to identify novel natural products and to prevent detection of already known compounds over and over again, e.g., the online platform Global Natural Products Social Molecular Networking [200], which uses MS/MS data to compare molecular features. Even though, a correlation between taxonomic distance and the production of distinct secondary metabolite families can be expected, as it was recently 
statistically verified for myxobacterial species [201], also closely related species might harbour new metabolites in challenging habitats, e.g., reefs.

In conclusion, the presented review of bioactive compounds obtained from heterobranchs shows the enormous potential of sea slugs if sufficient material can be obtained, or the food chain can be used to identify a compound. The structural diversity stretches from very diverse terpenes, e.g., the macfarlandines A-E (84-88) and briaranes (110-111) over peptides, e.g., kulolide (31), polyketides e.g., laulimalide (75) to complex imidazole alkaloids, e.g., 65, 66 and the highly cytotoxic jorumycin (121), as well as structures which should be biosynthesized by mixed biosynthetic pathways like the highly cytotoxic kabiramides $(\mathbf{1 2 5}, \mathbf{1 3 0}-\mathbf{1 3 3})$. Considering coral reef environments, it was shown that three genera of stony corals had distinct patterns of molecular relatedness, despite their high degree of taxonomic relatedness [202]. Further, it was indicated that even between individuals, different metabolomes exist, suggesting that every coral reef holobiont is a potential source of novel chemical diversity [202]. Hence, a biodiversity hot spot like BNP is a promising habitat for the detection of novel natural products and it underlines the need for biodiversity conservation to keep the reservoir of novel compounds beneficial for human wellbeing. In addition, the biodiversity hotspot of Indonesia is also a great place to study bio systems including food chain and defence mechanisms of sea slugs. 
Table 2. Bioactive natural products and their putative origin identified in Heterobranch families that have representatives at BNP.

\begin{tabular}{|c|c|c|c|c|c|c|}
\hline Clade & Family & Species & Location & Chemistry & (Presumable) Origin of Compound & References \\
\hline \multirow[t]{6}{*}{ Anaspidae (sea hares) } & Aplysiidae Lamarck, 1809 & Dolabella auricularia (Lightfoot, 1786) & $\begin{array}{l}\text { Western Indian Ocean } \\
\text { (Mauritius) }\end{array}$ & dolastatin $10(\mathbf{1})$ & dietary (cyanobacteria) & {$[21]$} \\
\hline & & $\begin{array}{c}\text { Stylocheilus striatus } \\
\text { (Quoy and Gaimard, 1832) }\end{array}$ & Australia (feeding study) & $\begin{array}{l}\text { debromoaplysiatoxin (3), } \\
\text { lyngbyatoxin } \mathrm{A}(6)\end{array}$ & $\begin{array}{l}\text { dietary (cyanobacteria } \\
\text { Lyngbya majuscula) }\end{array}$ & {$[22-26,32,37]$} \\
\hline & & $\begin{array}{c}\text { Stylocheilus longicauda } \\
\text { (Quoy and Gaimard, 1825) }\end{array}$ & $\begin{array}{c}\text { not given, } \\
\text { presumably Hawaii }\end{array}$ & $\begin{array}{c}\text { aplysiatoxin (2), } \\
\text { debromoaplysiatoxin (3) }\end{array}$ & dietary (cyanobacteria) & [22-26] \\
\hline & & $\begin{array}{l}\text { Stylocheilus longicauda } \\
\text { (Quoy and Gaimard, 1825) }\end{array}$ & $\begin{array}{l}\text { Black Point, } \\
\text { Oahu, Hawaii }\end{array}$ & $\begin{array}{c}\text { makalika ester (4), makalikone ester (5), } \\
\text { lyngbyatoxin A acetate (7), } \\
\text { malyngamide O (10) }\end{array}$ & dietary (cyanobacteria) & {$[27-31,35]$} \\
\hline & & $\begin{array}{c}\text { Stylocheilus longicauda } \\
\text { (Quoy and Gaimard, 1825) }\end{array}$ & $\begin{array}{c}\text { not given, } \\
\text { presumably Hawaii }\end{array}$ & kulolide-1 (31) & dietary (cyanobacteria) & [63] \\
\hline & & $\begin{array}{l}\text { Bursatella leachii } \\
\text { (Blainville, 1817) }\end{array}$ & Australia (feeding study) & lyngbyatoxin A (6) & dietary (cyanobacteria) & [37] \\
\hline \multirow[t]{11}{*}{ Sacoglossa } & Caliphyllidae Tiberi, 1881 & $\begin{array}{r}\text { Cyerce cristallina } \\
\text { (Trinchese, 1881) }\end{array}$ & Mediterranean Sea & $\begin{array}{c}\text { cyercene A (11) and B (12) and } \\
1-5(\mathbf{1 3 - 1 7 )} \\
\end{array}$ & de novo & {$[2,38]$} \\
\hline & & Cyerce nigricans (Pease, 1866) & Lizard Island (Australia) & chlorodesmin (18) & $\begin{array}{l}\text { diatery (green alga } \\
\text { Chlorodesmis fastigiata) }\end{array}$ & {$[39,40]$} \\
\hline & $\begin{array}{c}\text { Oxynoidae Stoliczka, } \\
1868(1847)\end{array}$ & $\begin{array}{l}\text { Lobiger serradifalci } \\
\text { (Calcara, 1840) }\end{array}$ & $\begin{array}{c}\text { Capo Miseno } \\
\text { (Bay of Naples, Italy) }\end{array}$ & oxytoxin-1 (20) & $\begin{array}{l}\text { modified from dietary caulerpynene (19) } \\
\text { from green alga Caulerpa prolifera }\end{array}$ & [41-43] \\
\hline & & $\begin{array}{c}\text { Oxynoe olivacea } \\
\text { (Rafinesque, 1814) }\end{array}$ & Murcia (SE Spain) & oxytoxin-1 (20), oxytoxin-2 (21) & $\begin{array}{l}\text { modified from dietary caulerpynene (19) } \\
\text { from green alga Caulerpa prolifera }\end{array}$ & [41-43] \\
\hline & & $\begin{array}{c}\text { Oxynoe olivacea } \\
\text { (Rafinesque, 1814) }\end{array}$ & Bay of Naples, Italy & oxytoxin-1 (20), oxytoxin-2 (21) & $\begin{array}{l}\text { modified from dietary caulerpynene (19) } \\
\text { from green alga Caulerpa prolifera }\end{array}$ & [41-43] \\
\hline & Plakobranchidae Gray, 1840 & Elysia chlorotica (Gould, 1870) & Bay of Fundy, Canada & elysione (22) & de novo & {$[3,51]$} \\
\hline & & Elysia viridis (Montagu, 1804) & $\begin{array}{l}\text { Fusaro Lake, Bay of } \\
\text { Naples, Italy }\end{array}$ & elysione (22) & de novo & {$[3,51]$} \\
\hline & & $\begin{array}{l}\text { Elysia translucens } \\
\text { (Pruvot-Fol, 1957) }\end{array}$ & $\begin{array}{c}\text { Capo Miseno, } \\
\text { Bay of Naples, Italy }\end{array}$ & udoteal (23) & $\begin{array}{l}\text { dietary from the green alga } \\
\text { Udotea petiolata }\end{array}$ & {$[3,40]$} \\
\hline & & $\begin{array}{l}\text { Elysia halimedae (Macnae 1954) } \\
\text { (accepted as Elysia pusilla } \\
\text { (Bergh, 1871)) }\end{array}$ & Agat Bay, Guam & halimedatetracetate alcohol (25) & $\begin{array}{l}\text { dietary (chemical modification of } \\
\text { halimedatetraacetate (24) from } \\
\text { Halimeda mucroloba Decaisne } \\
\text { (Carlson and Hoff, 1978)) }\end{array}$ & [52] \\
\hline & & Elysia rufescens (Pease, 1871) & Hawaii & $\begin{array}{l}\text { kahalalide F (26) and isokahalalide F } \\
\text { (27) }\end{array}$ & $\begin{array}{l}\text { dietary (algae Bryopsis pennata; might be } \\
\text { of bacterial origin, with Mycoplasma spp. } \\
\text { and Vibrio spp. as possible producers) }\end{array}$ & {$[46,53,55,57]$} \\
\hline & & Elysia ornata (Swainson, 1840) & coasts of Okha (India) & kahalalide $\mathrm{F}(\mathbf{2 6})$ and other kalahalides & $\begin{array}{l}\text { dietary (algae Bryopsis pennata; might be } \\
\text { of bacterial origin, with Mycoplasma spp. } \\
\text { and Vibrio spp. as possible producers) }\end{array}$ & {$[46,48]$} \\
\hline
\end{tabular}


Table 2. Cont.

\begin{tabular}{|c|c|c|c|c|c|c|}
\hline Clade & Family & Species & Location & Chemistry & (Presumable) Origin of Compound & References \\
\hline & & $\begin{array}{l}\text { Elysia grandifolia } \\
\text { (Kelaart, 1858) }\end{array}$ & $\begin{array}{l}\text { Gulf of Mannar and } \\
\text { Palk Bay, Rameswaram, } \\
\text { India at } 1 \text { to } 2 \mathrm{~m} \text { depth. }\end{array}$ & kahalalide F (26) and other kalahalides & $\begin{array}{l}\text { dietary (slugs were feeding on algae } \\
\text { Bryopsis plumosa (Hudson); might be of } \\
\text { bacterial origin, with Mycoplasma spp. } \\
\text { and Vibrio spp. as possible producers) }\end{array}$ & {$[46,54]$} \\
\hline & & Thuridilla hopei (Vérany, 1853) & Italy & thuridillins, e.g., thuridillin A (28) & $\begin{array}{c}\text { de novo, with precursor } \\
\text { derived from algae } \\
\text { Pseudochlorodesmis furcellata (30) }\end{array}$ & {$[58,60]$} \\
\hline & & $\begin{array}{l}\text { Thuridilla splendens } \\
\text { (Baba, 1949) }\end{array}$ & Australia & thuridillins & $\begin{array}{l}\text { de novo, with precursor derived from } \\
\text { algae P. furcellata (30) }\end{array}$ & {$[59,60]$} \\
\hline & & Thuridilla hopei (Vérany, 1853) & Italy & $\begin{array}{l}\text { thuridillin-related aldehydes, } \\
\text { e.g., nor-thuridillinal (29) }\end{array}$ & $\begin{array}{c}\text { de novo, with precursor derived from } \\
\text { algae P. furcellata (30) }\end{array}$ & {$[58,60]$} \\
\hline \multirow[t]{10}{*}{ Cephalaspidea } & $\begin{array}{l}\text { Aglajidae Pilsbry, } \\
1895 \text { (1847) }\end{array}$ & $\begin{array}{l}\text { Philinopsis speciosa } \\
\text { (Pease, 1860) }\end{array}$ & Hawaii & $\begin{array}{c}\text { Kulolide-1 (31), kulolide-2 (32), } \\
\text { kulolide-3 (33), kulokainalide-1 (34), } \\
\text { kulokahilide-1 (35), kulokahilide-1 (36) } \\
\text { as well as tolytoxin 23-acetate (37) }\end{array}$ & $\begin{array}{l}\text { dietary (cyanobacteria; transfer most } \\
\text { likely mediated via herbivorous } \\
\text { molluscs like Stylocheilus longicauda and } \\
\text { Dolabella auricularia which in turn were } \\
\text { readily accepted by P. speciosa in } \\
\text { feeding experiment) }\end{array}$ & {$[61-64]$} \\
\hline & & $\begin{array}{l}\text { Navanax inermis } \\
\text { (J. G. Cooper, 1862) }\end{array}$ & Pacific & $\begin{array}{l}\text { navenones A-C (39-41), isopulo' upone } \\
\text { (42), 5,6-dehydroaglajne-3 (43) }\end{array}$ & $\begin{array}{l}\text { dietary (Bulla species, } \\
\text { e.g., Bulla gouldiana) }\end{array}$ & {$[67,68,70]$} \\
\hline & Gastropteridae Swainson, 1840 & $\begin{array}{l}\text { Sagaminopteron psychedelicum } \\
\text { (Carlson and Hoff, 1974) }\end{array}$ & Guam & $\begin{array}{l}\text { 3,5 dibromo- 2-( } 2^{\prime}, 4^{\prime} \text {-dibromo- } \\
\text { phenoxy)phenol (47) }\end{array}$ & dietary (sponge Dysidea granulosa) & {$[71,72]$} \\
\hline & & $\begin{array}{l}\text { Sagaminopteron nigropunctatum } \\
\text { (Carlson and Hoff, 1973) }\end{array}$ & Guam & $\begin{array}{l}\text { 3,5 dibromo- } 2-\left(2^{\prime}, 4^{\prime}-\text { dibromo- }\right. \\
\text { phenoxy)phenol (47) }\end{array}$ & dietary (sponge Dysidea granulosa) & {$[71,73]$} \\
\hline & Haminoeidae Pilsbry, 1895 & $\begin{array}{c}\text { Haminoea cyanomarginata } \\
\text { (Heller and Thompson, 1983) }\end{array}$ & Gulf of Corinth (Greece) & brominated tetrahydropyran (48) & $\begin{array}{l}\text { dietary (Western Australian sponge } \\
\text { Haliclona sp. Grant, 1841) }\end{array}$ & [73] \\
\hline & & $\begin{array}{c}\text { Haminoea cymbalum } \\
\text { (Quoy and Gaimard, 1832) }\end{array}$ & Indian coasts & brominated tetrahydropyran (48) & dietary (sponge) & [73] \\
\hline & & $\begin{array}{c}\text { Haminoea cymbalum } \\
\text { (Quoy and Gaimard, 1832) }\end{array}$ & Guam & kumepaloxane (49) & dietary (sponge) & {$[74]$} \\
\hline & & Haminoea species & Naples (Italy) & $\begin{array}{l}\text { haminol A-C (50-52), and haminol 1-6 } \\
\text { (53-58) }\end{array}$ & de novo & {$[75,76]$} \\
\hline & & $\begin{array}{l}\text { Haminoea fusari (Alvarez, } \\
\text { Garcia and Villani, 1993) }\end{array}$ & Naples (Italy) & $\begin{array}{c}\text { polypropionates, } \\
\text { haminol 1-6 (53-58) }\end{array}$ & de novo & [77] \\
\hline & & $\begin{array}{l}\text { Haminoea orbignyana } \\
\text { (Férussac, 1822) }\end{array}$ & Naples (Italy) & haminol 1 and 2 (53-54) & $\begin{array}{l}\text { de novo synthesis, shown by } \\
\text { feeding study }\end{array}$ & [4] \\
\hline Pleurobranchomorpha & Pleurobranchidae Gray, 1827 & $\begin{array}{c}\text { Pleurobranchus forskalii } \\
\text { (Rüppell and Leuckart, 1828) }\end{array}$ & Manado, Indonesia & keenamide A (59) & $\begin{array}{l}\text { dietary (presumable } \\
\text { cyanobacterial origin) }\end{array}$ & [78] \\
\hline
\end{tabular}


Table 2. Cont

\begin{tabular}{|c|c|c|c|c|c|c|}
\hline Clade & Family & Species & Location & Chemistry & (Presumable) Origin of Compound & References \\
\hline & & $\begin{array}{c}\text { Pleurobranchus forskalii } \\
\text { (Rüppell and Leuckart, 1828) }\end{array}$ & Ishigaki Island, Japan & cycloforskamide (60) & $\begin{array}{l}\text { dietary (sponge with associated } \\
\text { cyanobacteria) or } \\
\text { symbiotic cyanobacteria }\end{array}$ & [79] \\
\hline & & $\begin{array}{c}\text { Pleurobranchus forskalii } \\
\text { (Rüppell and Leuckart, 1828) }\end{array}$ & Ishigaki Island, Japan & ergosinine (61) & $\begin{array}{l}\text { dietary (ascidian and/or } \\
\text { endophytic fungi) }\end{array}$ & [81] \\
\hline & & $\begin{array}{c}\text { Pleurobranchus forskalii } \\
\text { (Rüppell and Leuckart, 1828) }\end{array}$ & Philippines & $\begin{array}{l}\text { chlorolissoclimide (62) and } \\
\text { dichlorolissoclimide (63) }\end{array}$ & dietary (Lissoclinum species of ascidian) & {$[83,84]$} \\
\hline & & $\begin{array}{l}\text { Pleurobranchus albiguttatus } \\
\text { (Bergh, 1905) }\end{array}$ & Philippines & $\begin{array}{c}\text { chlorolissoclimide (62), } \\
\text { dichlorolissoclimide (63) and } \\
\text { 3ß-hydroxychlorolissoclimide (64) }\end{array}$ & dietary (Lissoclinum species of ascidian) & {$[83,84]$} \\
\hline \multirow[t]{13}{*}{$\begin{array}{l}\text { Nudibranchia } \\
\text { Anthobranchia }\end{array}$} & Aegiridae P. Fischer, 1883 & Notodoris citrina (Bergh, 1875) & Gulf of Eilat, The Red Sea & naamidine A (65), isonaamidine-A (66) & $\begin{array}{l}\text { dietary (sponge Leucetta chagosensis } \\
\text { Dendy, 1913) }\end{array}$ & [85-88] \\
\hline & & Notodoris gardineri (Eliot, 1906) & Philippines & $\begin{array}{l}\text { isonaamidine-A (66), } \\
\text { dorimidazole-A (67) }\end{array}$ & & {$[88,89]$} \\
\hline & & Notodoris gardineri (Eliot, 1906) & Great Barrier Reef & clathridine (68) & dietary (sponge) & {$[90,92,93]$} \\
\hline & & Notodoris gardineri (Eliot, 1906) & Papua New Guinea & clathridine (68) & $\begin{array}{c}\text { dietary (sponge Clathrina clathrus } \\
\text { Schmidt, 1864) }\end{array}$ & [91-93] \\
\hline & $\begin{array}{l}\text { Chromodorididae Bergh, } \\
1891\end{array}$ & $\begin{array}{l}\text { Ceratosoma атоенит } \\
\text { (Cheeseman, 1886) }\end{array}$ & Great Barrier Reef & allolaurinterol (69) & $\begin{array}{l}\text { dietary (origin could be red algae, e.g., } \\
\text { of the genus Laurencia; } 69 \text { also found in } \\
\text { cyanobacteria, via herbivorous } \\
\text { sea slugs) }\end{array}$ & [94-96] \\
\hline & & $\begin{array}{l}\text { Ceratosoma trilobatum } \\
\text { (J.E. Gray, 1827) }\end{array}$ & South China Sea Coast & $(-)$-furodysinin $(70)$ & dietary (sponge) & [97] \\
\hline & & $\begin{array}{l}\text { Ceratosoma gracillimum } \\
\text { (Semper in Bergh, 1876) }\end{array}$ & South China Sea Coast & (-)-furodysinin (70) & dietary (sponge) & [97] \\
\hline & & $\begin{array}{l}\text { Ceratosoma gracillimum } \\
\text { (Semper in Bergh, 1876) }\end{array}$ & $\begin{array}{l}\text { South Coast of } \\
\text { Hainan Island }\end{array}$ & (-)-furodysinin (70), nakafuran-9 (71) & dietary (sponge) & [97] \\
\hline & & Chromodoris lochi (Rudman, 1982) & Fiji & latrunculin A (72) & $\begin{array}{l}\text { dietary, } 72 \text { in Spongia (=Cacospongia) } \\
\text { mycofijiensis, but could be produced by } \\
\text { as yet uncultivated microorganism }\end{array}$ & {$[98,102]$} \\
\hline & & Chromodoris lochi (Rudman, 1982) & Vanuatu & mycothiazole (74) & $\begin{array}{l}\text { dietary, sponges, but could be produced } \\
\text { by as yet uncultivated microorganism }\end{array}$ & {$[103,104]$} \\
\hline & & Chromodoris lochi (Rudman, 1982) & Indonesia & $\begin{array}{c}\text { laulimalide (syn fijianolide B) (75), } \\
\text { isolaulimalide (syn fijianolide A) (76) }\end{array}$ & $\begin{array}{l}\text { dietary, sponges, but could be produced } \\
\text { by as yet uncultivated microorganism }\end{array}$ & [107-109] \\
\hline & & $\begin{array}{l}\text { Chromodoris hamiltoni (Rudman, } \\
\text { 1977) }\end{array}$ & South Africa & Lantrunculin A (72) and B (73) & dietary (sponge) & {$[100,102]$} \\
\hline & & Chromodoris elisabethina (Bergh, 1877) & Queensland, Australia & Lantrunculin A (72) and B (73) & dietary (sponge) & {$[101,102]$} \\
\hline
\end{tabular}


Table 2. Cont.

\begin{tabular}{|c|c|c|c|c|c|c|}
\hline \multirow[t]{14}{*}{ Clade } & Family & Species & Location & Chemistry & (Presumable) Origin of Compound & References \\
\hline & & $\begin{array}{c}\text { Chromodoris magnifica } \\
\text { (Quoy and Gaimard, 1832) }\end{array}$ & Queensland, Australia & Lantrunculin A (72) and B (73) & dietary (sponge) & {$[101,102]$} \\
\hline & & Chromodoris kuiteri (Rudman, 1982) & Queensland, Australia & Lantrunculin A (72) and B (73) & dietary (sponge) & {$[101,102]$} \\
\hline & & Chromodoris annae (Bergh, 1877) & Queensland, Australia & Lantrunculin A (72) and B (73) & dietary (sponge) & {$[101,102]$} \\
\hline & & $\begin{array}{c}\text { Chromodoris quadricolor } \\
\text { (Rüppell and Leuckart, 1830) }\end{array}$ & Red Sea & Lantrunculin A (72) and B (73) & dietary (sponge) & {$[101,102]$} \\
\hline & & $\begin{array}{c}\text { Chromodoris inorata (Pease, 1871) } \\
\text { (accepted as Chromodoris aspersa } \\
\text { (Gould, 1852)) }\end{array}$ & Japan & $\begin{array}{c}\text { inorolide A (77), B (78), C (79) and } \\
\text { various scalaranes }\end{array}$ & & [110] \\
\hline & & $\begin{array}{c}\text { Chromodoris luteorosea (Rapp, 1827) } \\
\text { (accepted as Felimida luteorosea } \\
\text { (Rapp, 1827)) }\end{array}$ & Spain & $\begin{array}{c}\text { norrisolide (80), polyrhaphin C (81), } \\
\text { chelonaplysin C (82), luterosin (83), } \\
\text { macfarlandin A (84), }\end{array}$ & dietary (sponge) & [111] \\
\hline & & $\begin{array}{l}\text { Chromodoris macfarlandi (Cockerell, } \\
\text { 1901) (accepted as Felimida } \\
\text { macfarlandi (Cockerell, 1901)) }\end{array}$ & California, USA & macfarlandines A-E (84-88) & $\begin{array}{l}\text { dietary (sponge, structures related to } \\
\text { compounds from Aplysilla sulphurea) }\end{array}$ & [111-113] \\
\hline & & $\begin{array}{l}\text { Chromodoris sinensis (Rudman, 1985) } \\
\text { (accepted as Goniobranchus sinensis } \\
\text { (Rudman, 1985)) }\end{array}$ & South China Sea & Aplyroseol-2 (89) & $\begin{array}{l}\text { dietary (sponge, structures related to } \\
\text { compounds from Aplysilla sp.) }\end{array}$ & [97] \\
\hline & & $\begin{array}{c}\text { Chromodoris reticulata (Quoy and } \\
\text { Gaimard, 1832) (accepted as } \\
\text { Goniobranchus reticulatus (Quoy and } \\
\text { Gaimard, 1832)) }\end{array}$ & Australia & Aplyroseol-2 (89) and other diterpenes & $\begin{array}{l}\text { dietary (sponge, structures related to } \\
\text { compounds from Aplysilla sp.) }\end{array}$ & [115] \\
\hline & & $\begin{array}{l}\text { Chromodoris maridadilus (Rudman, } \\
\text { 1977) (accepted as Hypselodoris } \\
\text { maridadilus (Rudman, 1977)) }\end{array}$ & Hawaii & nakafuran-9 (71), nakafuran-8 (90) & dietary (sponge Dysidea fragilis) & [116] \\
\hline & & $\begin{array}{c}\text { Glossodoris atromarginata } \\
\text { (Cuvier, 1804) (accepted as } \\
\text { Doriprismatica stellata (Cuvier, 1804)) }\end{array}$ & $\begin{array}{l}\text { Sri Lanka, } \\
\text { Australia, India }\end{array}$ & $\begin{array}{c}\text { furanoditerpenoid and scalarane type, } \\
\text { structural variants of these metabolites } \\
\text { (differences due to diff. sponge prey); } \\
\text { spongiadiol (91), spongiadiol diacetate } \\
\text { (92), epispongiadiol (93), } \\
\text { 12-deacetoxy-12-oxodooxocalarin (94), } \\
\text { heteronemin (95), mooloolabene D (96) }\end{array}$ & $\begin{array}{c}\text { dietary (sponge, e.g., Spongia sp. (former } \\
\text { Hyatella intestinales (Lamarck, 1814)), } \\
\text { Hyrtios erectus (Keller, 1889) and } \\
\text { Hyrtios sp.) }\end{array}$ & [117-131] \\
\hline & & $\begin{array}{l}\text { Glossodoris dalli (Bergh, 1879) } \\
\text { (accepted as Felimida dalli } \\
\text { (Bergh, 1879)) }\end{array}$ & $\begin{array}{l}\text { Natural Park of Osa } \\
\text { Ballena (Costa Rica) }\end{array}$ & $\begin{array}{l}\text { homoscalarane and } \\
\text { scalarane compounds }\end{array}$ & probably dietary from sponges & [132] \\
\hline & & $\begin{array}{c}\text { Glossodoris sedna (Ev. Marcus and Er. } \\
\text { Marcus, 1967) (accepted as } \\
\text { Doriprismatica sedna (Ev. Marcus and } \\
\text { Er. Marcus, 1967)) }\end{array}$ & $\begin{array}{l}\text { Natural Park of Osa } \\
\text { Ballena (Costa Rica) }\end{array}$ & $\begin{array}{l}\text { 12-deacetyl-23-acetoxy-20-methyl- } \\
\text { 12-episcalaradial (97) }\end{array}$ & probably dietary from sponges & [132] \\
\hline
\end{tabular}


Table 2. Cont

\begin{tabular}{|c|c|c|c|c|c|c|}
\hline \multirow[t]{16}{*}{ Clade } & Family & Species & Location & Chemistry & (Presumable) Origin of Compound & References \\
\hline & & $\begin{array}{l}\text { Glossodoris rufomarginata } \\
\text { (Bergh, 1890) }\end{array}$ & $\begin{array}{l}\text { Hainan Island in the } \\
\text { South China Sea }\end{array}$ & $\begin{array}{l}\text { homoscalarane and } \\
\text { scalarane compounds }\end{array}$ & probably dietary from sponges & [124] \\
\hline & & $\begin{array}{l}\text { Glossodoris pallida } \\
\text { (Rüppell and Leuckart, 1830) }\end{array}$ & China and Guam & $\begin{array}{l}\text { homoscalarane and scalarane } \\
\text { compounds, different pattern at } \\
\text { different location }\end{array}$ & probably dietary from sponges & [119] \\
\hline & & Glossodoris vespa (Rudman, 1990) & Eastern Australia & $\begin{array}{l}\text { homoscalarane and } \\
\text { scalarane compounds }\end{array}$ & probably dietary from sponges & [119] \\
\hline & & $\begin{array}{c}\text { Glossodoris averni (Rudman, 1985) } \\
\text { (accepted as Ardeadoris averni } \\
\text { (Rudman, 1985)) }\end{array}$ & Eastern Australia & $\begin{array}{l}\text { homoscalarane and } \\
\text { scalarane compounds }\end{array}$ & probably dietary from sponges & [119] \\
\hline & & $\begin{array}{l}\text { Goniobranchus obsoletus } \\
\text { (Rüppell and Leuckart, 1830) }\end{array}$ & Japan & $\begin{array}{c}\text { most bioactive: dorisenones A (98), } \\
\text { B (99), D (100), } \\
\begin{array}{c}\text { 11ß-hydroxyspongi-12-en-16-one (101), } \\
\text { spongian-16-one (102) }\end{array}\end{array}$ & dietary (sponge Spongionella sp.) & [133] \\
\hline & & $\begin{array}{l}\text { Goniobranchus splendidus } \\
\text { (Angas, 1864) }\end{array}$ & Australia & $\begin{array}{l}\text { spongian-16-one (102), aplytandiene-3 } \\
\text { (103), aplysulfurin (104) and } \\
\text { aplyroseol-2 (89), the gracilins A (105), B } \\
\text { (106), C (107), G (108), M (109)) }\end{array}$ & dietary (sponge Spongionella sp.) & {$[134,135,203]$} \\
\hline & & $\begin{array}{c}\text { Hypselodoris infucata } \\
\text { (Rüppell and Leuckart, 1830) }\end{array}$ & Hawaii & nakafuran-8 (90) and nakafuran-9 (71) & $\begin{array}{l}\text { dietary (sponge Dysidea fragilis } \\
\text { (Montagu, 1814)) }\end{array}$ & {$[116,138]$} \\
\hline & $\begin{array}{c}\text { Dendrodorididae } \\
\text { O'Donoghue, } 1924 \text { (1864) }\end{array}$ & Dendrodoris limbata (Cuvier, 1804) & & olepupuane (116) and polygodial (117) & de novo & {$[147,150-152]$} \\
\hline & Discodorididae Bergh, 1891 & $\begin{array}{l}\text { Halgerda aurantiomaculata } \\
\text { (Allan, 1932) }\end{array}$ & Japan, Australia & zooanemonin (118) and esmodil (119) & $\begin{array}{l}\text { dietary (sponge, anemone } \\
\text { Anemonia sulcate) }\end{array}$ & [153] \\
\hline & & $\begin{array}{l}\text { Halgerda gunnessi Fahey and } \\
\text { Gosliner, } 2001\end{array}$ & Japan, Australia & investigated, but no compounds found & & [153] \\
\hline & & $\begin{array}{c}\text { Halgerda rubicunda (Baba, 1949) } \\
\text { (accepted as Sclerodoris rubicunda } \\
\text { (Baba, 1949)) }\end{array}$ & Japan, Australia & investigated, but no compounds found & & [153] \\
\hline & & $\begin{array}{l}\text { Halgerda theobroma (Fahey and } \\
\text { Gosliner, 2001) }\end{array}$ & Japan, Australia & investigated, but no compounds found & & [153] \\
\hline & & Halgerda willeyi (Eliot, 1904) & Japan, Australia & investigated, but no compounds found & & [153] \\
\hline & & Paradoris indecora (Bergh, 1881) & Spain, Italy & variabilin (120) & dietary (sponge, e.g., Ircinia sp.) & [154] \\
\hline & & Jorunna funebris (Kelaart, 1859) & India & jorumycin (121) & $\begin{array}{l}\text { from structural similarity to } \\
\text { ecteinascidin } 743 \text { (122) bacterial origin }\end{array}$ & [155-157] \\
\hline
\end{tabular}


Table 2. Cont.

\begin{tabular}{|c|c|c|c|c|c|c|}
\hline Clade & Family & Species & Location & Chemistry & (Presumable) Origin of Compound & References \\
\hline & Hexabranchidae Bergh, 1891 & $\begin{array}{l}\text { Hexabranchus sanguineus } \\
\text { (Rüppell and Leuckart, 1830) }\end{array}$ & Hawaii, Japan & $\begin{array}{c}\text { Trisoxazole macrolides, i.e., ulapualide } \\
\text { A (123) and B (124), halichondramides } \\
\text { (126-129), kabiramide A-E } \\
\text { (125, 130-133), }\end{array}$ & $\begin{array}{c}\text { dietary, trisoxazole macrolides isolated } \\
\text { from different sponges from the genera } \\
\text { Halichondria, Mycale, Jaspis and } \\
\text { Pachastrissa. halichondramides (126-129) } \\
\text { isolated from sponge Halichondria sp. }\end{array}$ & [156-168] \\
\hline & Phyllidiidae Rafinesque, 1814 & Phyllidia coelestis (Bergh, 1905) & Thailand & $\begin{array}{l}\text { 1-formamido-10(1,2)-abeopupukeanane } \\
\text { (134), 2-formamidopupukeanane (135) }\end{array}$ & dietary (sponge) & {$[176,177]$} \\
\hline & & Phyllidia ocellata (Cuvier, 1804) & Japan & $\begin{array}{c}\text { cavernothiocyanate (136), } \\
\text { 10 } \alpha \text {-isocyano-4-amorphene (137), } \\
\text { axisonitrile-3 (138), and } \\
\text { 7-isocyano-7,8-dihydro- } \\
\alpha \text {-bisabolene (139) }\end{array}$ & $\begin{array}{l}\text { dietary ((136-139) from sponge } \\
\text { Acanthella cf. cavernosa) }\end{array}$ & [179] \\
\hline & & Phyllidia ocellata (Cuvier, 1804) & Australia & $\begin{array}{c}\text { 2-isocyanoclovene (140), } \\
\text { 2-isocyanoclovane (141), } \\
\text { 1-isothiocyanatoepicaryolane (142), } \\
\text { 4,5-epi-10-isocyanoisodauc-6-ene (143) }\end{array}$ & dietary (sponges) & [180] \\
\hline & & Phyllidia varicosa (Lamarck, 1801) & Hawaii & $\begin{array}{l}\text { 9-isocyanopupukeanane (144), } \\
\text { 2-isocyanopupukeanane (145) }\end{array}$ & $\begin{array}{l}\text { dietary, sponge Ciocalypta sp. } \\
\text { (ex. Hymeniacidon sp.) }\end{array}$ & {$[182,183]$} \\
\hline & & Phyllidia varicosa (Lamarck, 1801) & Indonesia & $\begin{array}{l}\text { 9-isocyanopupukeanane }(\mathbf{1 4 4}) \text {, epimeric } \\
\text { 9-thiocyanato-pupekeanane }(\mathbf{1 4 7}, \mathbf{1 4 8})\end{array}$ & $\begin{array}{l}\text { dietary, sponge Ciocalypta sp. } \\
\text { (ex. Hymeniacidon sp.) }\end{array}$ & [186] \\
\hline & & Phyllidia varicosa (Lamarck, 1801) & Sri Lanka & 3-isocyanotheonellin (146) & dietary (sponge) & [185] \\
\hline & & Phyllidiella rosans (Bergh, 1873) & Japan & 9-isocyanopupukeanane (144) & dietary (sponge) & [184] \\
\hline & & Phyllidiella pustulosa (Cuvier, 1804) & Japan & $\begin{array}{c}\text { axisonitrile-3 (138), unnamed molecule } \\
\text { with isocyano group (155) and } \\
\text { substituted axinisothiocyanate K } \\
\text { derivative }\end{array}$ & dietary (sponge) & [190] \\
\hline & & Phyllidiella pustulosa (Cuvier, 1804) & China & $\begin{array}{l}\text { 3-isocyanotheonellin (146), amphilectene } \\
\text { (152), kalihinol-A (153), kalihinol-E (154) }\end{array}$ & $\begin{array}{l}\text { dietary (sponges, due to very similar } \\
\text { compounds present in both samples) }\end{array}$ & [175] \\
\hline & & Phyllidiella pustulosa (Cuvier, 1804) & Vietnam & $\begin{array}{c}\text { 9-isocyanopupukeanane (144) and its } \\
\text { C-9 epimer }\end{array}$ & $\begin{array}{l}\text { dietary, based on the terpenes obtained } \\
\text { the authors concluded that the mollusk } \\
\text { feeds on sponges of the genera } \\
\text { Acanthella, Halichondria, Axinella } \\
\text { and Axinyssa }\end{array}$ & [189] \\
\hline & & Phyllidiella pustulosa (Cuvier, 1804) & Fiji & $\begin{array}{c}\text { axisonitrile-3 (138), } \\
\text { 10-isothiocyano-4-cadinene } \\
\text { (150)/10-thiocyanato-4-cadinene (151) }\end{array}$ & $\begin{array}{l}\text { sponge Phakellia carduus, due to very } \\
\text { similar secondary metabolites present in } \\
\text { both samples }\end{array}$ & {$[187,188]$} \\
\hline & $\begin{array}{l}\text { Polyceridae Alder and } \\
\text { Hancock, } 1845\end{array}$ & Tambja abdere (Farmer, 1978) & West coast of America & $\begin{array}{l}\text { tambjamines A-D, tambjamines A (156), } \\
\text { C (157) }\end{array}$ & $\begin{array}{c}\text { dietary (bryozoan } \\
\text { Sessibugula translucens) }\end{array}$ & [191] \\
\hline
\end{tabular}


Table 2. Cont

\begin{tabular}{|c|c|c|c|c|c|c|}
\hline Clade & Family & Species & Location & Chemistry & (Presumable) Origin of Compound & References \\
\hline & & $\begin{array}{l}\text { Tambja eliora (Er. Marcus and Ev. } \\
\text { Marcus, 1967) }\end{array}$ & West coast of America & $\begin{array}{l}\text { tambjamines A-D, tambjamines A (156), } \\
\text { C (157) }\end{array}$ & $\begin{array}{c}\text { dietary (bryozoan } \\
\text { Sessibugula translucens) }\end{array}$ & [191] \\
\hline & & Roboastra tigris (Farmer, 1978) & Gulf of California & $\begin{array}{l}\text { tambjamines A-D, tambjamines A (156), } \\
\text { C (157) }\end{array}$ & dietary (bryozoan Bugula neritida) & [191] \\
\hline & & Nembrotha species & Micronesia & $\begin{array}{c}\text { tambjamines A (156), C (157), E (158), } \\
\text { F (159), the tambjamine aldehyde (160) } \\
\text { and the blue tetrapyrrol (161) }\end{array}$ & dietary (ascidian Atapozoa sp.) & {$[138,192]$} \\
\hline & & Nembrotha cristata (Bergh, 1877) & Ant Atoll & $\begin{array}{l}\text { tambjamines A (156), C (157), E (158), } \\
\text { F (159), the tambjamine aldehyde (160) } \\
\text { and the blue tetrapyrrol (161) }\end{array}$ & dietary (ascidian Atapozoa sp.) & {$[138,192]$} \\
\hline & & Nembrotha kubaryana (Bergh, 1877) & $\begin{array}{l}\text { Sumilon Island, } \\
\text { the Philippines }\end{array}$ & $\begin{array}{c}\text { tambjamines C (157), E (158), and the } \\
\text { blue tetrapyrrol (161) }\end{array}$ & dietary (ascidian Atapozoa sp.) & {$[138,192]$} \\
\hline & & Nembrotha sp. & $\begin{array}{l}\text { Apo Islands, } \\
\text { the Philippines }\end{array}$ & $\begin{array}{l}\text { tambjamines C (157), E (158), F (159), } \\
\text { and the tambjamine aldehyde (160) }\end{array}$ & dietary (ascidian Atapozoa sp.) & [192] \\
\hline & & Polycera atra (MacFarland, 1905) & Torrey Pines artificial reef & bryostatins, e.g., bryostatin 1 (162) & dietary (bryozoan Bugula neritina) & [193-195] \\
\hline \multirow[t]{7}{*}{$\begin{array}{c}\text { Subclade } \\
\text { Cladobranchia }\end{array}$} & Facelinidae Bergh, 1889 & Phyllodesmium briareum (Bergh, 1896) & not known & $\begin{array}{c}\text { brianthein W (110) and excavatolide } \\
\text { C (111) }\end{array}$ & dietary (coral Briareum sp.) & [1] \\
\hline & & $\begin{array}{l}\text { Phyllodesmium magnum } \\
\text { (Rudman, 1991) }\end{array}$ & not known & $\begin{array}{l}\text { cembrane diterpenes, e.g., } \\
\text { 11-episinulariolide acetate (112) }\end{array}$ & dietary, e.g., Sinularia spp., Capnella sp. & [1] \\
\hline & Flabellinidae Bergh, 1889 & $\begin{array}{c}\text { Flabellina exoptata } \\
\text { (Gosliner and Willan, 1991) }\end{array}$ & not known & hormarin (113) & dietary & {$[139,141]$} \\
\hline & & $\begin{array}{c}\text { Flabellina ischitana } \\
\text { (Hirano and Thompson, 1990) }\end{array}$ & not known & hormarin (113) & dietary & {$[139,141]$} \\
\hline & & Flabellina pedata (Montagu, 1816) & not known & hormarin (113) & dietary & {$[139,141]$} \\
\hline & & Flabellina affinis (Gmelin, 1791) & not known & hormarin (113) & dietary & {$[139,141]$} \\
\hline & Proctonotidae Gray, 1853 & Janolus cristatus (Delle Chiaje, 1841) & Mediterranean & janolusimide (114) & dietary (bryozoa) & {$[139,141]$} \\
\hline
\end{tabular}


Acknowledgments: The authors thank Sam Ratulangi University (UNSRAT), Manado and the Republic of Indonesia for making this research possible. The material was legally collected with permits for the Bunaken national park to F.K. and T.F.S. No material is listed in IUCN or CITES. The DAAD is thanked for a scholarship to Z.G.W. The Federal Ministry of Education and Research (BMBF) funded the main part of this research project with the grants 16GW0117K and 16GW0118 to the Indobio consortium. The authors want to thank all the scientists contributing to the topic covered by this review. Our intention was to cite the corresponding literature comprehensively, however, if a piece of work was missed, we want to apologize to the respective authors.

Conflicts of Interest: The authors declare no conflict of interest.

\section{References}

1. Bogdanov, A.; Kehraus, S.; Bleidissel, S.; Preisfeld, G.; Schillo, D.; Piel, J.; Brachmann, A.O.; Wägele, H.; König, G.M. Defense in the Aeolidoidean Genus Phyllodesmium (Gastropoda). J. Chem. Ecol. 2014, 40, 1013-1024. [CrossRef] [PubMed]

2. Di Marzo, V.; Vardaro, R.R.; Petrocellis, L.D.; Villani, G.; Minei, R.; Cimino, G. Cyercenes, novel pyrones from the ascoglossan molluscCyerce cristallina. Tissue Distribution, Biosynthesis and Possible Involvement in Defense and Regenerative Processes. Experientia 1991, 47, 1221-1227. [CrossRef]

3. Gavagnin, M.; Marin, A.; Mollo, E.; Crispino, A.; Villani, G.; Cimino, G. Secondary Metabolites from Mediterranean Elysioidea: Origin and Biological Role. Comp. Biochem. Physiol. Part B Comp. Biochem. 1994, 108, 107-115. [CrossRef]

4. Cutignano, A.; Tramice, A.; De Caro, S.; Villani, G.; Cimino, G.; Fontana, A. Biogenesis of 3-Alkylpyridine Alkaloids in the Marine Mollusc Haminoea orbignyana. Angew. Chem.-Int. Ed. 2003, 42, 2633-2636. [CrossRef]

5. Pettit, G.R.; Kamano, Y.; Herald, C.L.; Fujii, Y.; Kizu, H.; Boyd, M.R.; Boettner, F.E.; Doubek, D.L.; Schmidt, J.M.; Chapuis, J.C.; et al. Isolation of Dolastatins 10-15 from the Marine Mollusc Dolabella auricularia. Tetrahedron 1993, 49, 9151-9170. [CrossRef]

6. Pettit, G.R.; Kamano, Y.; Herald, C.L.; Tuinman, A.A.; Boettner, F.E.; Kizu, H.; Schmidt, J.M.; Baczynskyj, L.; Tomer, K.B.; Bontems, R.J. The Isolation and Structure of a Remarkable Marine Animal Antineoplastic Constituent: Dolastatin 10. J. Am. Chem. Soc. 1987, 109, 6883-6885. [CrossRef]

7. Luesch, H.; Moore, R.E.; Paul, V.J.; Mooberry, S.L.; Corbett, T.H. Isolation of Dolastatin 10 from the Marine Cyanobacterium Symploca species VP642 and Total Stereochemistry and Biological Evaluation of Its Analogue Symplostatin 1. J. Nat. Prod. 2001, 64, 907-910. [PubMed]

8. Cimino, G.; Gavagnin, M. (Eds.) Molluscs: From Chemo-ecological Study to Biotechnological Application; Progress in Molecular and Subcellular Biology; Springer: Berlin/Heidelberg, Germany, 2006; Volume 43, ISBN 978-3-540-30879-9.

9. Benkendorff, K. Molluscan Biological and Chemical Diversity: Secondary Metabolites and Medicinal Resources Produced by Marine Molluscs. Biol. Rev. Camb. Philos. Soc. 2010, 85, 757-775. [CrossRef] [PubMed]

10. Debelius, H.; Kuiter, R.H. Nudibranchs of the World; IKAN-Unterwasserarchiv: Frankfurt, Germany, 2007; ISBN 978-3-939767-06-0.

11. Gosliner, T.; Behrens, D.W.; Valdés, Á. Indo-Pacific Nudibranchs and Sea Slugs: A Field Guide to the World's Most Diverse Fauna; Sea Challengers Natural History Books: San Francisco, CA, USA, 2008; ISBN 978-0-9700574-3-3.

12. Gosliner, T.; Valdés, Á.; Behrens, D.W. Nudibranch and Sea Slug Identification: Indo-Pacific; New World Publications, Inc.: Jacksonville, FL, USA, 2015; ISBN 978-1-878348-59-3.

13. Yonow, N. Results of the Rumphius Biohistorical Expedition to Ambon (1990) Part 15. The Suborder Doridina (Mollusca, Gastropods, Opisthobranchia, Nudibranchia). Zool. Meded. 2011, 85, 905-956.

14. Martynov, A.V.; Korshunova, T.A. Opisthobranch Molluscs of Vietnam (Gastropoda: Opisthobranchia). In Benthic fauna of the Bay of Nhatrang, Southern Vietnam; Britayev, T.A., Pavlov, D.S., Eds.; KMK Scientific Press Ltd.: Moscow, Russia, 2012; Volume 2, pp. 142-257. ISBN 978-5-87317-860-5.

15. Yonow, N. Results of the Rumphius Biohistorical Expedition to Ambon (1990). Part 11. Doridacea of the Families Chromodorididae and Hexabranchidae (Mollusca, Gastropoda, Opisthobranchia, Nudibranchia), Including Additional Moluccan Material. Zool. Meded. 2001, 75, 1-50.

16. Yonow, N. Results of the Rumphius Biohistorical Expedition to Ambon (1990). Part 16. The NudibranchiaDendronotina, Arminina, Aeolidina, and Doridina (Mollusca: Gastropoda: Heterobranchia). Arch. Molluskenkd. Int. J. Malacol. 2017, 146, 135-172. [CrossRef] 
17. Takamasa, Tonozuka. Opisthobranchs of Bali and Indonesia; Hankyu Communications Co. Ltd.: Tokyo, Japan, 2003; ISBN 4-484-03409-3. Available online: https:/ / combinedhunterunderwatergroup.weebly.com/uploads/1/1/2/3/ 11235330/indonesia-ssc_june_2017_-_album.pdf (accessed on 5 December 2017).

18. Burghardt, I.; Carvalho, R.; Eheberg, D.; Gerung, G.; Kaligis, F.; Mamangkey, G.; Schrödl, M.; Schwabe, E.; Vonnemann, V.; Wägele, H. Molluscan Diversity at Bunaken National Park, Sulawesi. J. Zool. Soc. Wallacea 2006, 2, 29-43.

19. Jensen, K.R. Evolution of the Sacoglossa (Mollusca, Opisthobranchia) and the ecological associations with their food plants. Evol. Ecol. 1997, 11, 301-335. [CrossRef]

20. Pereira, R.B.; Andrade, P.B.; Valentão, P. Chemical Diversity and Biological Properties of Secondary Metabolites from Sea Hares of Aplysia Genus. Mar. Drugs 2016, 14, 39. [CrossRef] [PubMed]

21. Harrigan, G.G.; Luesch, H.; Moore, R.E.; Paul, V.J. The Anticancer Dolastatins as Cyanobacterial Metabolites. In Biodiversity; Wrigley, S.K., Hayes, M.A., Thomas, R., Chrystal, E.J.T., Nicholson, N., Eds.; The Royal Society of Chemistry: Cambridge, UK, 2000; pp. 126-139.

22. Kato, Y.; Scheuer, P.J. Aplysiatoxin and Debromoaplysiatoxin, Constituents of the Marine Mollusk Stylocheilus longicauda (Quoy and Gaimard, 1824). J. Am. Chem. Soc. 1974, 96, 2245-2246. [CrossRef] [PubMed]

23. Watson, M. Midgut Gland Toxins of Hawaiian Sea Hares. I. Isolation and Preliminary Toxicological Observations. Toxicon 1973, 11, 259-267. [CrossRef]

24. Watson, M.; Rayner, M.D. Midgut Gland Toxins of Hawaiian Sea Hares. II. A Preliminary Pharmacological Study. Toxicon 1973, 11, 269-276. [CrossRef]

25. Moore, R.E. Toxins, Anticancer Agents, and Tumor Promoters from Marine Prokaryotes. Pure Appl. Chem. 1982, 54, 1919-1934. [CrossRef]

26. Ashida, Y.; Yanagita, R.C.; Takahashi, C.; Kawanami, Y.; Irie, K. Binding Mode Prediction of Aplysiatoxin, a Potent Agonist of Protein Kinase C, Through Molecular Simulation and Structure-Activity Study on Simplified Analogs of the Receptor-Recognition Domain. Bioorg. Med. Chem. 2016, 24, 4218-4227. [CrossRef] [PubMed]

27. Gallimore, W.A.; Galario, D.L.; Lacy, C.; Zhu, Y.; Scheuer, P.J. Two Complex Proline Esters from the Sea Hare Stylocheilus longicauda. J. Nat. Prod. 2000, 63, 1022-1026. [CrossRef] [PubMed]

28. Orjala, J.; Nagle, D.G.; Hsu, V.; Gerwick, W.H. Antillatoxin: An Exceptionally Ichthyotoxic Cyclic Lipopeptide from the Tropical Cyanobacterium Lyngbya majuscula. J. Am. Chem. Soc. 1995, 117, 8281-8282. [CrossRef]

29. White, J.D.; Hanselmann, R.; Wardrop, D.J. Synthesis of Epiantillatoxin, a Stereoisomer of the Potent Ichthyotoxin from Lyngbya majuscula. J. Am. Chem. Soc. 1999, 121, 1106-1107. [CrossRef]

30. Nagle, D.G.; Paul, V.J.; Ann Roberts, M. Ypaoamide, a New Broadly Acting Feeding Deterrent from the Marine Cyanobacterium Lyngbya majuscula. Tetrahedron Lett. 1996, 37, 6263-6266. [CrossRef]

31. Klein, D.; Braekman, J.-C.; Daloze, D.; Hoffmann, L.; Demoulin, V. Laingolide, a Novel 15-Membered Macrolide from Lyngbya bouillonii (cyanophyceae). Tetrahedron Lett. 1996, 37, 7519-7520. [CrossRef]

32. Cardellina, J.H.; Marner, F.J.; Moore, R.E. Seaweed Dermatitis: Structure of Lyngbyatoxin A. Science 1979, 204, 193-195. [CrossRef] [PubMed]

33. Edwards, D.J.; Gerwick, W.H. Lyngbyatoxin Biosynthesis: Sequence of Biosynthetic Gene Cluster and Identification of a Novel Aromatic Prenyltransferase. J. Am. Chem. Soc. 2004, 126, 11432-11433. [CrossRef] [PubMed]

34. Awakawa, T.; Zhang, L.; Wakimoto, T.; Hoshino, S.; Mori, T.; Ito, T.; Ishikawa, J.; Tanner, M.E.; Abe, I. A Methyltransferase Initiates Terpene Cyclization in Teleocidin B Biosynthesis. J. Am. Chem. Soc. 2014, 136, 9910-9913. [CrossRef] [PubMed]

35. Gallimore, W.A.; Scheuer, P.J. Malyngamides O and P from the Sea Hare Stylocheilus longicauda. J. Nat. Prod. 2000, 63, 1422-1424. [CrossRef] [PubMed]

36. Cardellina, J.H.; Marner, F.J.; Moore, R.E. Malyngamide A, a Novel Chlorinated Metabolite of the Marine Cyanophyte Lyngbya majuscula. J. Am. Chem. Soc. 1979, 101, 240-242. [CrossRef]

37. Capper, A.; Tibbetts, I.R.; O'Neil, J.M.; Shaw, G.R. The Fate of Lyngbya majuscula Toxins in Three Potential Consumers. J. Chem. Ecol. 2005, 31, 1595-1606. [CrossRef] [PubMed]

38. Vardaro, R.R.; Di Marzo, V.; Crispino, A.; Cimino, G. Cyercenes, Novel Polypropionate Pyrones from the Autotomizing Mediterranean Mollusc Cyerce cristallina. Tetrahedron 1991, 47, 5569-5576. [CrossRef]

39. Hay, M.E.; Pawlik, J.R.; Duffy, J.E.; Fenical, W. Seaweed-Herbivore-Predator Interactions: Host-Plant Specialization Reduces Predation on Small Herbivores. Oecologia 1989, 81, 418-427. [CrossRef] [PubMed] 
40. Paul, V.J.; Fenical, W. Chemical Defense in Tropical Green Algae, Order Caulerpales. Mar. Ecol. Prog. Ser. 1986, 34, 157-169. [CrossRef]

41. Gavagnin, M.; Marin, A.; Castelluccio, F.; Villani, G.; Cimino, G. Defensive Relationships between Caulerpa prolifera and Its Shelled Sacoglossan Predators. J. Exp. Mar. Biol. Ecol. 1994, 175, 197-210. [CrossRef]

42. Mozzachiodi, R.; Scuri, R.; Roberto, M.; Brunelli, M. Caulerpenyne, a Toxin from the Seaweed Caulerpa taxifolia, Depresses Afterhyperpolarization in Invertebrate Neurons. Neuroscience 2001, 107, 519-526. [CrossRef]

43. Ciavatta, M.L.; Lopez Gresa, M.P.; Gavagnin, M.; Manzo, E.; Mollo, E.; D’Souza, L.; Cimino, G. New Caulerpenyne-Derived Metabolites of an Elysia Sacoglossan from the South Indian Coast. Molecules 2006, 11, 808-816. [CrossRef] [PubMed]

44. Cimino, G.; Fontana, A.; Gavagnin, M. Marine Opisthobranch Molluscs: Chemistry and Ecology in Sacoglossans and Dorids. Curr. Org. Chem. 1999, 3, 327-372.

45. Cimino, G.; Ghiselin, M.T. Chemical Defense and the Evolution of Opisthobranch Gastropods; California Academy of Sciences: San Francisco, CA, USA, 2009; ISBN 978-0-940228-79-5.

46. Gao, J.; Hamann, M.T. Chemistry and Biology of Kahalalides. Chem. Rev. 2011, 111, 3208-3235. [CrossRef] [PubMed]

47. Carbone, M.; Muniain, C.; Castelluccio, F.; Iannicelli, O.; Gavagnin, M. First Chemical Study of the Sacoglossan Elysia patagonica: Isolation of a $\gamma$-pyrone propionate hydroperoxide. Biochem. Syst. Ecol. 2013, 49, 172-175. [CrossRef]

48. Ciavatta, M.L.; Devi, P.; Carbone, M.; Mathieu, V.; Kiss, R.; Casapullo, A.; Gavagnin, M. Kahalalide F Analogues from the Mucous Secretion of Indian Sacoglossan Mollusc Elysia ornata. Tetrahedron 2016, 72, 625-631. [CrossRef]

49. Gavagnin, M.; Mollo, E.; Montanaro, D.; Ortea, J.; Cimino, G. Chemical Studies of Caribbean Sacoglossans: Dietary Relationships with Green Algae and Ecological Implications. J. Chem. Ecol. 2000, 26, 1563-1578. [CrossRef]

50. Gavagnin, M.; Mollo, E.; Cimino, G. Is Phototridachiahydropyrone a True Natural Product? Rev. Bras. Farmacogn. 2015, 25, 588-591. [CrossRef]

51. Cutignano, A.; Cimino, G.; Villani, G.; Fontana, A. Shaping the Polypropionate Biosynthesis in the Solar-Powered Mollusc Elysia viridis. ChemBioChem 2009, 10, 315-322. [CrossRef] [PubMed]

52. Paul, V.J.; Van Alstyne, K.L. Use of Ingested Algal Diterpenoids by Elysia halimedae Macnae (Opisthobranchia: Ascoglossa) As Antipredator Defenses. J. Exp. Mar. Biol. Ecol. 1988, 119, 15-29. [CrossRef]

53. Hamann, M.T.; Scheuer, P.J. Kahalalide F: A Bioactive Depsipeptide from the Sacoglossan Mollusk Elysia rufescens and the Green Alga Bryopsis sp. J. Am. Chem. Soc. 1993, 115, 5825-5826. [CrossRef]

54. Ashour, M.; Edrada, R.; Ebel, R.; Wray, V.; Wätjen, W.; Padmakumar, K.; Müller, W.E.G.; Lin, W.H.; Proksch, P. Kahalalide Derivatives from the Indian Sacoglossan Mollusk Elysia grandifolia. J. Nat. Prod. 2006, 69, 1547-1553. [CrossRef] [PubMed]

55. Hamann, M.T.; Otto, C.S.; Scheuer, P.J.; Dunbar, D.C. Kahalalides: Bioactive Peptides from a Marine Mollusk Elysia rufescens and Its Algal Diet Bryopsis sp. (1). J. Org. Chem. 1996, 61, 6594-6600. [CrossRef] [PubMed]

56. Wang, B.; Waters, A.L.; Valeriote, F.A.; Hamann, M.T. An Efficient and Cost-Effective Approach to Kahalalide F N-Terminal Modifications Using a Nuisance Algal Bloom of Bryopsis pennata. Biochim. Biophys. Acta BBA-Gen. Subj. 2015, 1850, 1849-1854. [CrossRef] [PubMed]

57. Davis, J.; Fricke, W.F.; Hamann, M.T.; Esquenazi, E.; Dorrestein, P.C.; Hill, R.T. Characterization of the Bacterial Community of the Chemically Defended Hawaiian Sacoglossan Elysia rufescens. Appl. Environ. Microbiol. 2013, 79, 7073-7081. [CrossRef] [PubMed]

58. Gavagnin, M.; Spinella, A.; Crispino, A.; Epifanio, R.; Marin, A.; Cimino, G. Chemical-Components of the Mediterranean Ascoglossan Thuridilla hopei. Gazzetta Chim. Ital. 1993, 123, 205-208.

59. Somerville, M.J.; Katavic, P.L.; Lambert, L.K.; Pierens, G.K.; Blanchfield, J.T.; Cimino, G.; Mollo, E.; Gavagnin, M.; Banwell, M.G.; Garson, M.J. Isolation of Thuridillins D-F, Diterpene Metabolites from the Australian Sacoglossan Mollusk Thuridilla splendens; Relative Configuration of the Epoxylactone Ring. J. Nat. Prod. 2012, 75, 1618-1624. [CrossRef] [PubMed]

60. Paul, V.; Ciminiello, P.; Fenical, W. Diterpenoid Feeding Deterrents from the Pacific Green-Alga Pseudochlorodesmis furcellata. Phytochemistry 1988, 27, 1011-1014. [CrossRef] 
61. Reese, M.T.; Gulavita, N.K.; Nakao, Y.; Hamann, M.T.; Yoshida, W.Y.; Coval, S.J.; Scheuer, P.J. Kulolide: A Cytotoxic Depsipeptide from a Cephalaspidean Mollusk, Philinopsis speciosa ${ }^{1}$. J. Am. Chem. Soc. 1996, 118, 11081-11084. [CrossRef]

62. Kimura, J.; Takada, Y.; Inayoshi, T.; Nakao, Y.; Goetz, G.; Yoshida, W.Y.; Scheuer, P.J. Kulokekahilide-1, a Cytotoxic Depsipeptide from the Cephalaspidean Mollusk Philinopsis speciosa. J. Org. Chem. 2002, 67, 1760-1767. [CrossRef] [PubMed]

63. Nakao, Y.; Yoshida, W.Y.; Szabo, C.M.; Baker, B.J.; Scheuer, P.J. More Peptides and Other Diverse Constituents of the Marine Mollusk Philinopsis speciosa. J. Org. Chem. 1998, 63, 3272-3280. [CrossRef]

64. Nakao, Y.; Yoshida, W.Y.; Takada, Y.; Kimura, J.; Yang, L.; Mooberry, S.L.; Scheuer, P.J. Kulokekahilide-2, a Cytotoxic Depsipeptide from a Cephalaspidean Mollusk Philinopsis speciosa. J. Nat. Prod. 2004, 67, 1332-1340. [CrossRef] [PubMed]

65. Cruz-Rivera, E.; Paul, V.J. Chemical Deterrence of a Cyanobacterial Metabolite Against Generalized and Specialized Grazers. J. Chem. Ecol. 2007, 33, 213-217. [CrossRef] [PubMed]

66. Boudreau, P.D.; Byrum, T.; Liu, W.-T.; Dorrestein, P.C.; Gerwick, W.H. Viequeamide A, a Cytotoxic Member of the Kulolide Superfamily of Cyclic Depsipeptides from a Marine Button Cyanobacterium. J. Nat. Prod. 2012, 75, 1560-1570. [CrossRef] [PubMed]

67. Sleeper, H.L.; Fenical, W. Navenones A-C: Trail-Breaking Alarm Pheromones from the Marine Opisthobranch Navanax inermis. J. Am. Chem. Soc. 1977, 99, 2367-2368. [CrossRef]

68. Marin, A.; Alvarez, L.A.; Cimino, G.; Spinella, A. Chemical Defence in Cephalaspidean Gastropods: Origin, Anatomical Location and Ecological Roles. J. Molluscan Stud. 1999, 65, 121-131. [CrossRef]

69. Cimino, G.; Sodano, G.; Spinella, A. New Propionate-Derived Metabolites from Aglaja depicta and from Its Prey Bulla striata (Opisthobranch Mollusks). J. Org. Chem. 1987, 52, 5326-5331. [CrossRef]

70. Spinella, A.; Alvarez, L.A.; Cimino, G. Predator-Prey Relationship between Navanax inermis and Bulla gouldiana: A Chemical Approach. Tetrahedron 1993, 49, 3203-3210. [CrossRef]

71. Becerro, M.A.; Starmer, J.A.; Paul, V.J. Chemical Defenses of Cryptic and Aposematic Gastropterid Molluscs Feeding on Their Host Sponge Dysidea granulosa. J. Chem. Ecol. 2006, 32, 1491-1500. [CrossRef] [PubMed]

72. Ortlepp, S.; Pedpradap, S.; Dobretsov, S.; Proksch, P. Antifouling Activity of Sponge-Derived Polybrominated Diphenyl Ethers and Synthetic Analogues. Biofouling 2008, 24, 201-208. [CrossRef] [PubMed]

73. Mollo, E.; Gavagnin, M.; Carbone, M.; Castelluccio, F.; Pozone, F.; Roussis, V.; Templado, J.; Ghiselin, M.T.; Cimino, G. Factors Promoting Marine Invasions: A Chemoecological Approach. Proc. Natl. Acad. Sci. USA 2008, 105, 4582-4586. [CrossRef] [PubMed]

74. Poiner, A.; Paul, V.J.; Scheuer, P.J. Kumepaloxane, a Rearranged Trisnor Sesquiterpene from the Bubble Shell Haminoea cymbalum. Tetrahedron 1989, 45, 617-622. [CrossRef]

75. Spinella, A.; Alvarez, L.; Passeggio, A.; Cimino, G. New 3-Alkylpyridines from 3 Mediterranean Cephalaspidean Mollusks-Structure, Ecological Role and Taxonomic Relevance. Tetrahedron 1993, 49, 1307-1314. [CrossRef]

76. Blihoghe, D.; Manzo, E.; Villela, A.; Cutignano, A.; Picariello, G.; Faimali, M.; Fontana, A. Evaluation of the Antifouling Properties of 3-Alyklpyridine Compounds. Biofouling 2011, 27, 99-109. [CrossRef] [PubMed]

77. Cutignano, A.; Blihoghe, D.; Fontana, A.; Villani, G.; d'Ippolito, G.; Cimino, G. Fusaripyrones, Novel Polypropionates from the Mediterranean Mollusc Haminoea fusari. Tetrahedron 2007, 63, 12935-12939. [CrossRef]

78. Wesson, K.J.; Hamann, M.T. Keenamide A, a Bioactive Cyclic Peptide from the Marine Mollusk Pleurobranchus forskalii. J. Nat. Prod. 1996, 59, 629-631. [CrossRef] [PubMed]

79. Tan, K.C.; Wakimoto, T.; Takada, K.; Ohtsuki, T.; Uchiyama, N.; Goda, Y.; Abe, I. Cycloforskamide, a Cytotoxic Macrocyclic Peptide from the Sea Slug Pleurobranchus forskalii. J. Nat. Prod. 2013, 76, 1388-1391. [CrossRef] [PubMed]

80. Sivonen, K.; Leikoski, N.; Fewer, D.P.; Jokela, J. Cyanobactins-Ribosomal Cyclic Peptides Produced by Cyanobacteria. Appl. Microbiol. Biotechnol. 2010, 86, 1213-1225. [CrossRef] [PubMed]

81. Wakimoto, T.; Tan, K.C.; Abe, I. Ergot Alkaloid from the Sea Slug Pleurobranchus forskalii. Toxicon 2013, 72, 1-4. [CrossRef] [PubMed]

82. Mulac, D.; Humpf, H.-U. Cytotoxicity and Accumulation of Ergot Alkaloids in Human Primary Cells. Toxicology 2011, 282, 112-121. [CrossRef] [PubMed] 
83. Fu, X.; Palomar, A.J.; Hong, E.P.; Schmitz, F.J.; Valeriote, F.A. Cytotoxic Lissoclimide-Type Diterpenes from the Molluscs Pleurobranchus albiguttatus and Pleurobranchus forskalii. J. Nat. Prod. 2004, 67, 1415-1418. [CrossRef] [PubMed]

84. Robert, F.; Gao, H.Q.; Donia, M.; Merrick, W.C.; Hamann, M.T.; Pelletier, J. Chlorolissoclimides: New Inhibitors of Eukaryotic Protein Synthesis. RNA 2006, 12, 717-725. [CrossRef] [PubMed]

85. Carmelya, S.; Ilanb, M.; Kashmana, Y. 2-Amino Imidazole Alkaloids from the Marine Sponge Leucetta chagosensis. Tetrahedron 1989, 45, 2193-2200. [CrossRef]

86. Copp, B.R.; Fairchild, C.R.; Cornell, L.; Casazza, A.M.; Robinson, S.; Ireland, C.M. Naamidine A Is an Antagonist of the Epidermal Growth Factor Receptor and an in Vivo Active Antitumor Agent. J. Med. Chem. 1998, 41, 3909-3911. [CrossRef] [PubMed]

87. LaBarbera, D.V.; Modzelewska, K.; Glazar, A.I.; Gray, P.D.; Kaur, M.; Liu, T.; Grossman, D.; Harper, M.K.; Kuwada, S.K.; Moghal, N.; et al. The Marine Alkaloid Naamidine A Promotes Caspase-Dependent Apoptosis in Tumor Cells. Anticancer Drugs 2009, 20, 425-436. [CrossRef] [PubMed]

88. Mai, T.; Tintillier, F.; Lucasson, A.; Moriou, C.; Bonno, E.; Petek, S.; Magré, K.; Al Mourabit, A.; Saulnier, D.; Debitus, C. Quorum Sensing Inhibitors from Leucetta chagosensis Dendy, 1863. Lett. Appl. Microbiol. 2015, 61, 311-317. [CrossRef] [PubMed]

89. Alvi, K.A.; Crews, P.; Loughhead, D.G. Structures and Total Synthesis of 2-Aminoimidazoles from a Notodoris Nudibranch. J. Nat. Prod. 1991, 54, 1509-1515. [CrossRef]

90. Carroll, A.R.; Bowden, B.F.; Coll, J.C. New Imidazole Alkaloids from the Sponge Leucetta sp. and the Associated Predatory Nudibranch Notodoris gardineri. Aust. J. Chem. 1993, 468, 1229-1234. [CrossRef]

91. Alvi, K.A.; Peters, B.M.; Lisa, H.M.; Phillip, C. 2-Aminoimidazoles and Their Zinc Complexes from Indo-Pacific Leucetta sponges and Notodoris nudibranchs. Tetrahedron 1993, 49, 329-336. [CrossRef]

92. Ciminiello, P.; Fattorusso, E.; Magno, S.; Mangoni, A. Clathridine and Its Zinc Complex, Novel Metabolites from the Marine Sponge Clathrina clathrus. Tetrahedron 1989, 45, 3873-3878. [CrossRef]

93. Roué, M.; Domart-Coulon, I.; Ereskovsky, A.; Djediat, C.; Perez, T.; Bourguet-Kondracki, M.-L. Cellular Localization of Clathridimine, an Antimicrobial 2-Aminoimidazole Alkaloid Produced by the Mediterranean Calcareous Sponge Clathrina clathrus. J. Nat. Prod. 2010, 73, 1277-1282. [CrossRef] [PubMed]

94. Grkovic, T.; Appleton, D.R.; Copp, B.R. Chemistry and Chemical Ecology of some of the Common Opisthobranch Molluscs Found on the Shores of NE New Zealand. Chem. N. Z. 2005, 69, 12.

95. König, G.M.; Wright, A.D. Sesquiterpene Content of the Antibacterial Dichloromethane Extract of the Marine Red Alga Laurencia obtusa. Planta Med. 1997, 63, 186-187. [CrossRef] [PubMed]

96. Vairappan, C.S.; Kawamoto, T.; Miwa, H.; Suzuki, M. Potent Antibacterial Activity of Halogenated Compounds against Antibiotic-Resistant Bacteria. Planta Med. 2004, 70, 1087-1090. [CrossRef] [PubMed]

97. Carbone, M.; Gavagnin, M.; Haber, M.; Guo, Y.-W.; Fontana, A.; Manzo, E.; Genta-Jouve, G.; Tsoukatou, M.; Rudman, W.B.; Cimino, G.; et al. Packaging and Delivery of Chemical Weapons: A Defensive Trojan Horse Stratagem in Chromodorid Nudibranchs. PLoS ONE 2013, 8, e62075. [CrossRef] [PubMed]

98. Kakou, Y.; Crews, P.; Bakus, G.J. Dendrolasin and Latrunculin A from the Fijian Sponge Spongia mycofijiensis and an Associated Nudibranch Chromodoris lochi. J. Nat. Prod. 1987, 50, 482-484. [CrossRef]

99. Kashman, Y.; Groweiss, A.; Shmueli, U. Latrunculin, a New 2-Thiazolidinone Macrolide from the Marine Sponge Latrunculia magnifica. Tetrahedron Lett. 1980, 21, 3629-3632. [CrossRef]

100. Pika, J.; Faulkner, D.J. Unusual Chlorinated Homo-Diterpenes from the South African Nudibranch Chromodoris hamiltoni. Tetrahedron 1995, 51, 8189-8198. [CrossRef]

101. Cheney, K.L.; White, A.; Mudianta, I.W.; Winters, A.E.; Quezada, M.; Capon, R.J.; Mollo, E.; Garson, M.J. Choose Your Weaponry: Selective Storage of a Single Toxic Compound, Latrunculin A, by Closely Related Nudibranch Molluscs. PLoS ONE 2016, 11, e0145134. [CrossRef] [PubMed]

102. El Sayed, K.A.; Youssef, D.T.A.; Marchetti, D. Bioactive Natural and Semisynthetic Latrunculins. J. Nat. Prod. 2006, 69, 219-223. [CrossRef] [PubMed]

103. Crews, P.; Kakou, Y.; Quinoa, E. Mycothiazole, a Polyketide Heterocycle from a Marine Sponge. J. Am. Chem. Soc. 1988, 110, 4365-4368. [CrossRef]

104. Sonnenschein, R.N.; Johnson, T.A.; Tenney, K.; Valeriote, F.A.; Crews, P. A Reassignment of (-)-Mycothiazole and the Isolation of a Related Diol. J. Nat. Prod. 2006, 69, 145-147. [CrossRef] [PubMed] 
105. Morgan, J.B.; Mahdi, F.; Liu, Y.; Coothankandaswamy, V.; Jekabsons, M.B.; Johnson, T.A.; Sashidhara, K.V.; Crews, P.; Nagle, D.G.; Zhou, Y.-D. The Marine Sponge Metabolite Mycothiazole: A Novel Prototype Mitochondrial Complex I Inhibitor. Bioorg. Med. Chem. 2010, 18, 5988-5994. [CrossRef] [PubMed]

106. Meyer, K.J.; Singh, A.J.; Cameron, A.; Tan, A.S.; Leahy, D.C.; O'Sullivan, D.; Joshi, P.; La Flamme, A.C.; Northcote, P.T.; Berridge, M.V.; et al. Mitochondrial Genome-Knockout Cells Demonstrate a Dual Mechanism of Action for the Electron Transport Complex I Inhibitor Mycothiazole. Mar. Drugs 2012, 10, 900-917. [CrossRef] [PubMed]

107. Corley, D.G.; Herb, R.; Moore, R.E.; Scheuer, P.J.; Paul, V.J. Laulimalides. New Potent Cytotoxic Macrolides from a Marine Sponge and a Nudibranch Predator. J. Org. Chem. 1988, 53, 3644-3646. [CrossRef]

108. Mooberry, S.L.; Randall-Hlubek, D.A.; Leal, R.M.; Hegde, S.G.; Hubbard, R.D.; Zhang, L.; Wender, P.A. Microtubule-Stabilizing Agents Based on Designed Laulimalide Analogues. Proc. Natl. Acad. Sci. USA 2004, 101, 8803-8808. [CrossRef] [PubMed]

109. Churchill, C.D.M.; Klobukowski, M.; Tuszynski, J.A. Analysis of the Binding Mode of Laulimalide to Microtubules: Establishing a Laulimalide-Tubulin Pharmacophore. J. Biomol. Struct. Dyn. 2016, 34, 1455-1469. [CrossRef] [PubMed]

110. Miyamoto, T.; Sakamoto, K.; Amano, H.; Arakawa, Y.; Nagarekawa, Y.; Komori, T.; Higuchi, R.; Sasaki, T. New Cytotoxic Sesterterpenoids from the Nudibranch Chromodoris inornata. Tetrahedron 1999, 55, 9133-9142. [CrossRef]

111. Gavagnin, M.; Vardaro, R.; Avila, C.; Cimino, G.; Ortea, J. Ichthyotoxic Diterpenoids from the Cantabrian Nudibranch Chromodoris luteorosea. J. Nat. Prod. 1992, 55, 368-371. [CrossRef] [PubMed]

112. Molinski, T.F.; Faulkner, D.J. Aromatic Norditerpenes from the Nudibranch Chromodoris macfarlandi. J. Org. Chem. 1986, 51, 2601-2603. [CrossRef]

113. Molinski, T.F.; Faulkner, D.J.; He, C.H.; Van Duyne, G.D.; Clardy, J. Three New Rearranged Spongian Diterpenes from Chromodoris macfarlandi: Reappraisal of the Structures of Dendrillolides A and B. J. Org. Chem. 1986, 51, 4564-4567. [CrossRef]

114. Schnermann, M.J.; Beaudry, C.M.; Egorova, A.V.; Polishchuk, R.S.; Suetterlin, C.; Overman, L.E. Golgi-Modifying Properties of Macfarlandin E and the Synthesis and Evaluation Of Its 2,7-Dioxabicyclo[3.2.1]Octan-3-One Core. Proc. Natl. Acad. Sci. USA 2010, 107, 6158-6163. [CrossRef] [PubMed]

115. Suciati; Lambert, L.K.; Garson, M.J. Structures and Anatomical Distribution of Oxygenated Diterpenes in the Australian Nudibranch Chromodoris reticulata. Aust. J. Chem. 2011, 64, 757-765. [CrossRef]

116. Schulte, G.; Scheuer, P.J.; McConnell, O.J. Two Furanosesquiterpene Marine Metabolites with Antifeedant Properties. Helv. Chim. Acta 1980, 63, 2159-2167. [CrossRef]

117. De Silva, E.D.; Scheuer, P.J. Furanoditerpenoids from the Dorid Nudibranch Casella atromarginata. Heterocycles 1982, 17, 167-170. [CrossRef]

118. Karuso, P. Chemical Ecology of the Nudibranchs. In Bioorganic Marine Chemistry; Scheuer, P.P.J., Ed.; Bioorganic Marine Chemistry; Springer: Berlin/Heidelberg, Germany, 1987; pp. 31-60. ISBN 978-3-642-72728-3.

119. Manzo, E.; Gavagnin, M.; Somerville, M.J.; Mao, S.-C.; Ciavatta, M.L.; Mollo, E.; Schupp, P.J.; Garson, M.J.; Guo, Y.-W.; Cimino, G. Chemistry of Glossodoris Nudibranchs: Specific Occurrence of 12-Keto Scalaranes. J. Chem. Ecol. 2007, 33, 2325-2336. [CrossRef] [PubMed]

120. Fontana, A.; Cavaliere, P.; Ungur, N.; D'Souza, L.; Parameswaram, P.S.; Cimino, G. New Scalaranes from the Nudibranch Glossodoris atromarginata and Its Sponge Prey. J. Nat. Prod. 1999, 62, 1367-1370. [CrossRef] [PubMed]

121. Gross, H.; Wright, A.D.; Reinscheid, U.; König, G.M. Three New Spongian Diterpenes from the Fijian Marine Sponge Spongia sp. Nat. Prod. Commun. 2009, 4, 315-322. [PubMed]

122. Somerville, M.J.; Mollo, E.; Cimino, G.; Rungprom, W.; Garson, M.J. Spongian Diterpenes from Australian Nudibranchs: An Anatomically Guided Chemical Study of Glossodoris atromarginata. J. Nat. Prod. 2006, 69, 1086-1088. [CrossRef] [PubMed]

123. Betancur-Galvis, L.; Zuluaga, C.; Arnó, M.; González, M.A.; Zaragozá, R.J. Cytotoxic Effect (on Tumor Cells) and in Vitro Antiviral Activity against Herpes Simplex Virus of Synthetic Spongiane Diterpenes. J. Nat. Prod. 2002, 65, 189-192. [CrossRef] [PubMed]

124. Gavagnin, M.; Mollo, E.; Docimo, T.; Guo, Y.-W.; Cimino, G. Scalarane Metabolites of the Nudibranch Glossodoris rufomarginata and Its Dietary Sponge from the South China Sea. J. Nat. Prod. 2004, 67, 2104-2107. [CrossRef] [PubMed] 
125. Kamel, H.N.; Kim, Y.B.; Rimoldi, J.M.; Fronczek, F.R.; Ferreira, D.; Slattery, M. Scalarane Sesterterpenoids: Semisynthesis and Biological Activity. J. Nat. Prod. 2009, 72, 1492-1496. [CrossRef] [PubMed]

126. Wu, S.-Y.; Sung, P.-J.; Chang, Y.-L.; Pan, S.-L.; Teng, C.-M. Heteronemin, a Spongean Sesterterpene, Induces Cell Apoptosis and Autophagy in Human Renal Carcinoma Cells. BioMed Res. Int. 2015, 2015, e738241. [CrossRef] [PubMed]

127. Kohmoto, S.; Mcconnell, O.J.; Wright, A.; Cross, S. Isospongiadiol, a Cytotoxic and Antiviral Diterpene from a Caribbean Deep Water Marine Sponge, Spongia sp. Chem. Lett. 1987, 16, 1687-1690. [CrossRef]

128. Agrawal, M. Isolation and Structural Elucidation of Cytotoxic Agents from Marine Invertebrates and Plants Sourced from the Great Barrier Reef, Australia. Ph.D. Thesis, James Cook University, Townsville, Australia, 2007.

129. Yong, K.W.; Garson, M.J.; Bernhardt, P.V. Absolute Structures and Conformations of the Spongian Diterpenes Spongia-13(16), 14-dien-3-one, Epispongiadiol and Spongiadiol. Acta Crystallogr. Sect. C Cryst. Struct. Commun. 2009, 65, o167-o170. [CrossRef] [PubMed]

130. Longley, R.E.; McConnell, O.J.; Essich, E.; Harmody, D. Evaluation of Marine Sponge Metabolites for Cytotoxicity and Signal Transduction Activity. J. Nat. Prod. 1993, 56, 915-920. [CrossRef] [PubMed]

131. Wonganuchitmeta, S.; Yuenyongsawad, S.; Keawpradub, N.; Plubrukarn, A. Antitubercular Sesterterpenes from the Thai Sponge Brachiaster sp. J. Nat. Prod. 2004, 67, 1767-1770. [CrossRef] [PubMed]

132. Fontana, A.; Mollo, E.; Ortea, J.; Gavagnin, M.; Cimino, G. Scalarane and Homoscalarane Compounds from the Nudibranchs Glossodoris sedna and Glossodoris dalli: Chemical and Biological Properties. J. Nat. Prod. 2000, 63, 527-530. [CrossRef] [PubMed]

133. Miyamoto, T.; Sakamoto, K.; Arao, K.; Komori, T.; Higuchi, R.; Sasaki, T. Dorisenones, cytotoxic spongian diterpenoids, from the nudibranch Chromodoris obsoleta. Tetrahedron 1996, 52, 8187-8198. [CrossRef]

134. Hirayama, Y.; Katavic, P.L.; White, A.M.; Pierens, G.K.; Lambert, L.K.; Winters, A.E.; Kigoshi, H.; Kita, M.; Garson, M.J. New Cytotoxic Norditerpenes from the Australian Nudibranchs Goniobranchus splendidus and Goniobranchus daphne. Aust. J. Chem. 2016, 69, 136-144. [CrossRef]

135. Rueda, A.; Losada, A.; Fernandez, R.; Cabanas, C.; Garcia-Fernandez, L.F.; Reyes, F.; Cuevas, C. Gracilins G-I, Cytotoxic Bisnorditerpenes from Spongionella pulchella, and the Anti-Adhesive Properties of Gracilin B. Lett. Drug Des. Discov. 2006, 3, 753-760. [CrossRef]

136. Andoni Sanchez, J.; Alfonso, A.; Leiros, M.; Alonso, E.; Rateb, M.E.; Jaspars, M.; Houssen, W.E.; Ebel, R.; Tabudravu, J.; Botana, L.M. Identification of Spongionella Compounds as Cyclosporine A Mimics. Pharmacol. Res. 2016, 107, 407-414. [CrossRef] [PubMed]

137. Leiros, M.; Alonso, E.; Rateb, M.E.; Houssen, W.E.; Ebel, R.; Jaspars, M.; Alfonso, A.; Botana, L.M. Gracilins: Spongionella-Derived Promising Compounds for Alzheimer Disease. Neuropharmacology 2015, 93, 285-293. [CrossRef] [PubMed]

138. Karuso, P.; Scheuer, P.J. Natural Products from Three Nudibranchs: Nembrotha kubaryana, Hypselodoris infucata and Chromodoris petechialis. Molecules 2002, 7, 1-6. [CrossRef]

139. Putz, A.; König, G.M.; Wägele, H. Defensive Strategies of Cladobranchia (Gastropoda, Opisthobranchia). Nat. Prod. Rep. 2010, 27, 1386-1402. [CrossRef] [PubMed]

140. Frick, K. Response in Nematocyst Uptake by the Nudibranch Flabellina verrucosa to the Presence of Various Predators in the Southern Gulf of Maine. Biol. Bull. 2003, 205, 367-376. [CrossRef] [PubMed]

141. Affeld, S.; Wägele, H.; Avila, C.; Kehraus, S.; König, G.M. Distribution of Homarine in some Opisthobranchia (Gastropoda: Mollusca). Bonn. Zool. Beitr. 2006, 55, 181-190.

142. Sodano, G.; Spinella, A. Janolusimide, a Lipophilic Tripeptide Toxin from the Nudibranch Mollusk Janolus cristatus. Tetrahedron Lett. 1986, 27, 2505-2508. [CrossRef]

143. Wang, J.; Prinsep, M.R.; Gordon, D.P.; Page, M.J.; Copp, B.R. Isolation and Stereospecific Synthesis of Janolusimide B from a New Zealand Collection of the Bryozoan Bugula flabellata. J. Nat. Prod. 2015, 78, 530-533. [CrossRef] [PubMed]

144. Benkendorff, K.; Davis, A.R.; Bremner, J.B. Chemical Defense in the Egg Masses of Benthic Invertebrates: An Assessment of Antibacterial Activity in 39 Mollusks and 4 Polychaetes. J. Invertebr. Pathol. 2001, 78, 109-118. [CrossRef] [PubMed]

145. Cimino, G.; Ghiselin, M.T. Chemical Defense and Evolutionary Trends in Biosynthetic Capacity among Dorid Nudibranchs (Mollusca: Gastropoda: Opisthobranchia). Chemoecology 1999, 9, 187-207. [CrossRef]

146. Faulkner, D.J. Marine Natural Products. Nat. Prod. Rep. 2001, 18, 1R-49R. [CrossRef] 
147. Gavagnin, M.; Mollo, E.; Castelluccio, F.; Ghiselin, M.T.; Calado, G.; Cimino, G. Can Molluscs Biosynthesize Typical Sponge Metabolites? The Case of the Nudibranch Doriopsilla areolata. Tetrahedron 2001, 57, 8913-8916. [CrossRef]

148. Sakio, Y.; Hirano, Y.J.; Hayashi, M.; Komiyama, K.; Ishibashi, M. Dendocarbins A-N, New Drimane Sesquiterpenes from the Nudibranch Dendrodoris carbunculosa. J. Nat. Prod. 2001, 64, 726-731. [CrossRef] [PubMed]

149. Kubo, I.; Nakanishi, K. Insect Antifeedants and Repellents from African Plants. In Host Plant Resistance to Pests; ACS Symposium Series; American Chemical Society: Washington, DC, USA, 1977; Volume 62, pp. 165-178. ISBN 978-0-8412-0389-1.

150. Cimino, G.; De Rosa, S.; De Stefano, S.; Sodano, G.; Villani, G. Dorid Nudibranch Elaborates Its Own Chemical Defense. Science 1983, 219, 1237-1238. [CrossRef] [PubMed]

151. Kubo, I.; Taniguchi, M. Polygodial, an Antifungal Potentiator. J. Nat. Prod. 1988, 51, 22-29. [CrossRef] [PubMed]

152. Cimino, G.; Sodano, G.; Spinella, A. Occurrence of Olepupuane in Two Mediterranean Nudibranchs: A Protected Form of Polygodial. J. Nat. Prod. 1988, 51, 1010-1011. [CrossRef] [PubMed]

153. Fahey, S.J.; Carroll, A.R. Natural Products Isolated from Species of Halgerda Bergh, 1880 (Mollusca: Nudibranchia) and Their Ecological and Evolutionary Implications. J. Chem. Ecol. 2007, 33, 1226-1234. [CrossRef] [PubMed]

154. Marin, A.; Belluga, M.D.L.; Scognamiglio, G.; Cimino, G. Morphological and Chemical Camouflage of the Mediterranean Nudibranch Discodoris indecora on the Sponges Ircinia variabilis and Ircinia fasciculata. J. Molluscan Stud. 1997, 63, 431-439. [CrossRef]

155. Fontana, A.; Cavaliere, P.; Wahidulla, S.; Naik, C.G.; Cimino, G. A New Antitumor Isoquinoline Alkaloid from the Marine Nudibranch Jorunna funebris. Tetrahedron 2000, 56, 7305-7308. [CrossRef]

156. Newman, D.J.; Cragg, G.M. Marine-Sourced Anti-Cancer and Cancer Pain Control Agents in Clinical and Late Preclinical Development. Mar. Drugs 2014, 12, 255-278. [CrossRef] [PubMed]

157. Newman, D.J.; Cragg, G.M. Drugs and Drug Candidates from Marine Sources: An Assessment of the Current "State of Play". Planta Med. 2016, 82, 775-789. [CrossRef] [PubMed]

158. Menchaca, R.; Martínez, V.; Rodríguez, A.; Rodríguez, N.; Flores, M.; Gallego, P.; Manzanares, I.; Cuevas, C. Synthesis of Natural Ecteinascidins (ET-729, ET-745, ET-759B, ET-736, ET-637, ET-594) from Cyanosafracin B. J. Org. Chem. 2003, 68, 8859-8866. [CrossRef] [PubMed]

159. Roesener, J.A.; Scheuer, P.J. Ulapualide A and B, Extraordinary Antitumor Macrolides from Nudibranch Eggmasses. J. Am. Chem. Soc. 1986, 108, 846-847. [CrossRef]

160. Matsunaga, S.; Fusetani, N.; Hashimoto, K.; Koseki, K.; Noma, M. Bioactive Marine Metabolites. Part 13. Kabiramide C, a Novel Antifungal Macrolide from Nudibranch Eggmasses. J. Am. Chem. Soc. 1986, 108, 847-849. [CrossRef]

161. Parrish, S.M.; Yoshida, W.; Yang, B.; Williams, P.G. Ulapualides C-E Isolated from a Hawaiian Hexabranchus sanguineus Egg Mass. J. Nat. Prod. 2017, 80, 726-730. [CrossRef] [PubMed]

162. Pawlik, J.R.; Kernan, M.R.; Molinski, T.F.; Harper, M.K.; Faulkner, D.J. Defensive Chemicals of the Spanisch Dancer Nudibranch Hexabranchus sanguineus and Its Egg Ribbons: Macrolides Derived from a Sponge Diet. J. Exp. Mar. Biol. Ecol. 1988, 119, 99-109. [CrossRef]

163. Matsunaga, S.; Fusetani, N.; Hashimoto, K.; Koseki, K.; Noma, M.; Noguchi, H.; Sankawa, U. Bioactive Marine Metabolites. 25. Further Kabiramides and Halichondramides, Cytotoxic Macrolides Embracing Trisoxazole, from the Hexabranchus egg masses. J. Org. Chem. 1989, 54, 1360-1363. [CrossRef]

164. Kernan, M.R.; Molinski, T.F.; Faulkner, D.J. Macrocyclic Antifungal Metabolites from the Spanish Dancer Nudibranch Hexabranchus sanguineus and Sponges of the Genus Halichondria. J. Org. Chem. 1988, 53, 5014-5020. [CrossRef]

165. Klenchin, V.A.; Allingham, J.S.; King, R.; Tanaka, J.; Marriott, G.; Rayment, I. Trisoxazole Macrolide Toxins Mimic the Binding of Actin-Capping Proteins to Actin. Nat. Struct. Biol. 2003, 10, 1058-1063. [CrossRef] [PubMed]

166. Melville, J.L.; Moal, I.H.; Baker-Glenn, C.; Shaw, P.E.; Pattenden, G.; Hirst, J.D. The Structural Determinants of Macrolide-Actin Binding: In Silico Insights. Biophys. J. 2007, 92, 3862-3867. [CrossRef] [PubMed] 
167. Kobayashi, K.; Fujii, Y.; Hirayama, Y.; Kobayashi, S.; Hayakawa, I.; Kigoshi, H. Design, Synthesis, and Biological Evaluations of Aplyronine A-Mycalolide B Hybrid Compound. Org. Lett. 2012, 14, 1290-1293. [CrossRef] [PubMed]

168. Pereira, J.H.; Petchprayoon, C.; Hoepker, A.C.; Moriarty, N.W.; Fink, S.J.; Cecere, G.; Paterson, I.; Adams, P.D.; Marriott, G. Structural and Biochemical Studies of Actin in Complex with Synthetic Macrolide Tail Analogues. ChemMedChem 2014, 9, 2286-2293. [CrossRef] [PubMed]

169. Matsunaga, S. Trisoxazole macrolides from Hexabranchus Nudibranchs and Other Marine Invertebrates. Prog. Mol. Subcell. Biol. 2006, 43, 241-260. [PubMed]

170. Ueoka, R.; Uria, A.R.; Reiter, S.; Mori, T.; Karbaum, P.; Peters, E.E.; Helfrich, E.J.N.; Morinaka, B.I.; Gugger, M.; Takeyama, H.; et al. Metabolic and Evolutionary Origin of Actin-Binding Polyketides from Diverse Organisms. Nat. Chem. Biol. 2015, 11, 705-712. [CrossRef] [PubMed]

171. Yeung, K.-S.; Paterson, I. Actin-Binding Marine Macrolides: Total Synthesis and Biological Importance. Angew. Chem. Int. Ed. 2002, 41, 4632-4653. [CrossRef] [PubMed]

172. Tetlow, D.J.; Winder, S.J.; Aïssa, C. The Synthesis and Biological Evaluation of a Kabiramide C Fragment Modified with a WH2 Consensus Actin-Binding Motif as a Potential Disruptor of the Actin Cytoskeleton. Chem. Commun. 2016, 52, 807-810. [CrossRef] [PubMed]

173. Stoffels, B.E.M.W.; van der Meij, S.E.T.; Hoeksema, B.W.; van Alphen, J.; van Alen, T.; Meyers-Muñoz, M.A.; Voogd, N.J.D.; Tuti, Y.; van der Velde, G. Phylogenetic relationships within the Phyllidiidae (Opisthobranchia, Nudibranchia). ZooKeys 2016, 605, 1-35. [CrossRef]

174. Ritson-Williams, R.; Paul, V.J. Marine Benthic Invertebrates Use Multimodal Cues for Defense against Reef Fish. Mar. Ecol. Prog. Ser. 2007, 340, 29-39. [CrossRef]

175. Manzo, E.; Ciavatta, M.L.; Gavagnin, M.; Mollo, E.; Guo, Y.-W.; Cimino, G. Isocyanide Terpene Metabolites of Phyllidiella pustulosa, a Nudibranch from the South China Sea. J. Nat. Prod. 2004, 67, 1701-1704. [CrossRef] [PubMed]

176. Dumdei, E.J.; Flowers, A.E.; Garson, M.J.; Moore, C.J. The Biosynthesis of Sesquiterpene Isocyanides and Isothiocyanates in the Marine Sponge Acanthella cavernosa (Dendy); Evidence for Dietary Transfer to the Dorid Nudibranch Phyllidiella pustulosa. Comp. Biochem. Physiol. A Physiol. 1997, 118, 1385-1392. [CrossRef]

177. Jaisamut, S.; Prabpai, S.; Tancharoen, C.; Yuenyongsawad, S.; Hannongbua, S.; Kongsaeree, P.; Plubrukarn, A. Bridged Tricyclic Sesquiterpenes from the Tubercle Nudibranch Phyllidia coelestis Bergh. J. Nat. Prod. 2013, 76, 2158-2161. [CrossRef] [PubMed]

178. Zhukova, N.V. Lipid Classes and Fatty Acid Composition of the Tropical Nudibranch Mollusks Chromodoris sp. and Phyllidia coelestis. Lipids 2007, 42, 1169-1175. [CrossRef] [PubMed]

179. Fusetani, N.; Wolstenholme, H.J.; Shinoda, K.; Asai, N.; Matsunaga, S.; Onuki, H.; Hirota, H. Two Sesquiterpene Isocyanides and a Sesquiterpene Thiocyanate from the Marine Sponge Acanthella cf. cavernosa and the Nudibranch Phyllidia ocellata. Tetrahedron Lett. 1992, 33, 6823-6826. [CrossRef]

180. White, A.M.; Pierens, G.K.; Skinner-Adams, T.; Andrews, K.T.; Bernhardt, P.V.; Krenske, E.H.; Mollo, E.; Garson, M.J. Antimalarial Isocyano and Isothiocyanato Sesquiterpenes with Tri- and Bicyclic Skeletons from the Nudibranch Phyllidia ocellata. J. Nat. Prod. 2015, 78, 1422-1427. [CrossRef] [PubMed]

181. Fahrner, A.; Schrodl, M. Taxonomic Revision of the Common Indo-West Pacific Nudibranch Phyllidia varicosa Lamarck, 1801. Veliger 2000, 43, 164-171.

182. Burreson, B.J.; Scheuer, P.J.; Finer, J.; Clardy, J. 9-Isocyanopupukeanane, a Marine Invertebrate Allomone with a New Sesquiterpene Skeleton. J. Am. Chem. Soc. 1975, 97, 4763-4764. [CrossRef]

183. Hagadone, M.R.; Burreson, B.J.; Scheuer, P.J.; Finer, J.S.; Clardy, J. Defense Allomones of the Nudibranch Phyllidia varicosa Lamarck 1801. Helv. Chim. Acta 1979, 62, 2484-2494. [CrossRef]

184. Fusetani, N.; Wolstenholme, H.J.; Matsunaga, S. Co-Occurrence of 9-Isocyanopupukeanane and Its C-9 Epimer in the Nudibranch Phyllidia bourguini. Tetrahedron Lett. 1990, 31, 5623-5624. [CrossRef]

185. Gulavita, N.K.; de Silva, E.D.; Hagadone, M.R.; Karuso, P.; Scheuer, P.J.; van Duyne, G.D.; Clardy, J. Nitrogenous Bisabolene Sesquiterpenes from Marine Invertebrates. J. Org. Chem. 1986, 51, 5136-5139. [CrossRef]

186. Yasman; Edrada, R.A.; Wray, V.; Proksch, P. New 9-Thiocyanatopupukeanane Sesquiterpenes from the Nudibranch Phyllidia varicosa and Its Sponge-Prey Axinyssa aculeata. J. Nat. Prod. 2003, 66, 1512-1514. [CrossRef] 
187. Wright, A.D. GC-MS and NMR analysis of Phyllidiella pustulosa and One of Its Dietary Sources, the Sponge Phakellia carduus. Comp. Biochem. Physiol. A. Mol. Integr. Physiol. 2003, 134, 307-313. [CrossRef]

188. Nishikawa, K.; Umezawa, T.; Garson, M.J.; Matsuda, F. Confirmation of the Configuration of 10-Isothiocyanato4-cadinene Diastereomers through Synthesis. J. Nat. Prod. 2012, 75, 2232-2235. [CrossRef] [PubMed]

189. Lyakhova, E.G.; Kolesnikova, S.A.; Kalinovskii, A.I.; Stonik, V.A. Secondary Metabolites of the Vietnamese Nudibranch Mollusk Phyllidiella pustulosa. Chem. Nat. Compd. 2010, 46, 534-538. [CrossRef]

190. Jomori, T.; Shibutani, T.; Ahmadi, P.; Suzuka, T.; Tanaka, J. A New Isocyanosesquiterpene from the Nudibranch Phyllidiella pustulosa. Nat. Prod. Commun. 2015, 10, 1913-1914.

191. Carte, B.; Faulkner, D. Role of Secondary Metabolites in Feeding Associations between a Predatory Nudibranch, 2 Grazing Nudibranchs, and a Bryozoan. J. Chem. Ecol. 1986, 12, 795-804. [CrossRef] [PubMed]

192. Paul, V.; Lindquist, N.; Fenical, W. Chemical Defenses of the Tropical Ascidian Atapozoa sp. and Its Nudibranch Predators Nembrotha spp. Mar. Ecol. Prog. Ser. 1990, 59, 109-118. [CrossRef]

193. Trindade-Silva, A.E.; Lim-Fong, G.E.; Sharp, K.H.; Haygood, M.G. Bryostatins: Biological Context and Biotechnological Prospects. Curr. Opin. Biotechnol. 2010, 21, 834-842. [CrossRef] [PubMed]

194. Davidson, S.K. The Biology of the Bryostatins in the Marine Bryozoan Bugula neritina. Ph. D. Thesis, University of California, San Diego, CA, USA, 1999.

195. Lim, G.E. Bugula (Bryozoa) and Their Bacterial Symbionts: A Study in Symbiosis, Molecular Phylogenetics and Secondary Metabolism. Ph. D. Thesis, University of California, San Diego, CA, USA, 2004.

196. Sudek, S.; Lopanik, N.B.; Waggoner, L.E.; Hildebrand, M.; Anderson, C.; Liu, H.; Patel, A.; Sherman, D.H.; Haygood, M.G. Identification of the Putative Bryostatin Polyketide Synthase Gene Cluster from "Candidatus endobugula sertula", the Uncultivated Microbial Symbiont of the Marine Bryozoan Bugula neritina. J. Nat. Prod. 2007, 70, 67-74. [CrossRef] [PubMed]

197. Ciavatta, M.L.; Lefranc, F.; Carbone, M.; Mollo, E.; Gavagnin, M.; Betancourt, T.; Dasari, R.; Kornienko, A.; Kiss, R. Marine Mollusk-Derived Agents with Antiproliferative Activity as Promising Anticancer Agents to Overcome Chemotherapy Resistance. Med. Res. Rev. 2017, 37, 702-801. [CrossRef] [PubMed]

198. Böhringer, N.; Fisch, K.M.; Schillo, D.; Bara, R.; Hertzer, C.; Grein, F.; Eisenbarth, J.-H.; Kaligis, F.; Schneider, T.; Wägele, H.; et al. Antimicrobial Potential of Bacteria Associated with Marine Sea Slugs from North Sulawesi, Indonesia. Front. Microbiol. 2017, 8, 1092. [CrossRef] [PubMed]

199. Fisch, K.M.; Schäberle, T.F. Toolbox for Antibiotics Discovery from Microorganisms. Arch. Pharm. 2016, 349, 683-691. [CrossRef] [PubMed]

200. Wang, M.; Carver, J.J.; Phelan, V.V.; Sanchez, L.M.; Garg, N.; Peng, Y.; Nguyen, D.D.; Watrous, J.; Kapono, C.A.; Luzzatto-Knaan, T.; et al. Sharing and Community Curation of Mass Spectrometry Data with Global Natural Products Social Molecular Networking. Nat. Biotechnol. 2016, 34, 828-837. [CrossRef] [PubMed]

201. Hoffmann, T.; Krug, D.; Bozkurt, N.; Duddela, S.; Jansen, R.; Garcia, R.; Gerth, K.; Steinmetz, H.; Müller, R. Bacterial versus Chemical Diversity: The Taxonomy Paradigm in Microbial Natural Product Discovery. Nat. Commun. 2017. accepted.

202. Hartmann, A.C.; Petras, D.; Quinn, R.A.; Protsyuk, I.; Archer, F.I.; Ransome, E.; Williams, G.J.; Bailey, B.A.; Vermeij, M.J.A.; Alexandrov, T.; et al. Meta-Mass Shift Chemical Profiling of Metabolomes from Coral Reefs. Proc. Natl. Acad. Sci. USA 2017, 114, 11685-11690. [CrossRef] [PubMed]

203. Wilson, N.G.; Winters, A.E.; Cheney, K.L. Tropical Range Extension for the Temperate, Endemic South-Eastern Australian Nudibranch Goniobranchus splendidus (Angas, 1864). Diversity 2016, 8, 16. [CrossRef]

(C) 2017 by the authors. Licensee MDPI, Basel, Switzerland. This article is an open access article distributed under the terms and conditions of the Creative Commons Attribution (CC BY) license (http://creativecommons.org/licenses/by/4.0/). 